\title{
OVER DEN CHINASCHEN HANDEL DER OOST-INDISCHE COMPAGNIE IN DE EERSTE DERTIG JAAR VAN DE $18^{\circ}$ EEUW.
}

DOoR Dr. J. DE H ULL U.

Met geen ander land in het Oosten heeft de Compagnie zoo laat vaste, onafgebroken handelsbetrekkingen aangeknoopt als met China. Een tijdlang weliswaar, in de dagen van Coen, schenen de omstandigheden gunstig genoeg om haar het uitzicht te openen op een volslagen monopoliseering van de negotie op dat rijk. Men vleide zich met de hoop, dat men de Portugeezen en Spanjaarden daar geheel uit zou kunnen verdringen, de Portugeezen door ze uit Macao weg te drijven of wel door de vaart van daar op Malakka en Japan te beletten, waartoe men slechts gedurende eenige maanden van het jaar de haven van Macao behoefde te blokkeeren en de schepen had te onderscheppen, die derwaarts kwamen aanzetten, - de Spanjaarden door in het daarvoor aangewezen seizoen de voor Manilla bestemde Chineesche jonken te overweldigen en zoo mogelijk ook de zilverschepen, die van uit Zuid-Amerika naar de Philippijnen werden afgezonden. Slaagde dit plan dan zou de Compagnie, zoo oordeelde men, meester zijn van het gansche verkeer tusschen China en Japan. De Japanners toch hadden groote hoeveelheden noodig van Chineesche koopmanschappen en konden die niet anders verkrijgen dan door tusschenpersonen, aangezien zij wegens vijandelijkheden vroeger door hen in China gepleegd daar te lande geen handel mochten komen drijven. Verder zou in dat geval al wat het Oosten en Europa aan Chineesche goederen behoefde uitsluitend door de Compagnie moeten geleverd worden, en aan den anderen kant China alleen door haar bemiddeling in het bezit kunnen geraken van al die waren, welke het van buitenslands placht te ontvangen. ${ }^{1-}$

1 Groeneveldt, De Nederlanders in China (1601-1624) in Bijdr. Kon. Instituut, deel 48 blz. 58 vlg. 
Maar noch dit veelomvattend streven noch de meer bescheiden pogingen, in den loop der $17^{\mathrm{e}}$ eeuw aangewend om in China vrijheid te verkrijgen voor een permanenten handel, hebben tot het beoogde doel geleid. Op zijn hoogst slaagde men er in nu en dan van den keizer verlof te bekomen om binnen zeker tijdsverloop, acht, vijf of twee jaar, een hoeveelheid goederen ten verkoop aan te brengen, als een tribuut of cijns, gelijk de Chineezen het voorstelden, door de vreemde barbaren aan den zoon des Hemels verschuldigd. '

Winstgevend zijn die bezendingen voor de Compagnie niet geweest: gedeeltelijk ook, het is waar, tengevolge van de wijze. waarop men te Batavia de zaak aanvatte. "De experientie heeft geleerd (zoo schreven de Zeventien in 1695 aan GouverneurGeneraal en Raden) hoe slecht het doorgaans daarmede is uitgevallen en hoe sobere winsten wij op onze aangevoerde koopmanschappen hebben behaald, alhoewel wij tot ons smartelijk leedwezen moeten zeggen dat men daaromtrent niet heeft gebruikt gehad die conduite en dat bestier, dat wij billijklijk van UEd. hadden verwacht, als zijnde doorgaans derwaarts gezonden vele verlegen goederen en koopmanschappen daar men te Batavia geen weg mede wist, dat men om die mede tegelijk kwijt te raken de andere goederen verre beneden de waarde heeft moeten afstaan, daar men ter contrarie daartoe niet anders hadde behooren te gebruiken dan deugdelijk en welgetrokken goed en waarop gevolgelijk geheel andere avancen ${ }^{2}$ te behalen zouden zijn geweest." Ook had men, naar hun oordeel, "tot het bestier van dien handel geëmployeerd personen daar gansch onbedreven, en zulks t'eenemaal onkundig hoe men met die schrandere en bedriegelijke natie moet omgaan en behoort te handelen, hebbende haar in de hand laten steken veel slecht en ondeugend goed; men laat nog staan (zeggen zij) dat men 'nu en dan drie en vier schepen derwaarts heeft gezonden met zoo een gansch sobere ladinge zoo in volumen als in waarde dat men, de kosten en lasten gerekend, in plaats van voordeel schade heeft behaald.» ${ }^{3}$

1 Schlegel, De betrekkingen tusschen Nederland en China volgens Chineesche berichten in Bijdr. deel $42 \mathrm{blz} .1 \mathrm{vlg}$.

? Winsten.

3 Brief van de XVII aan GG. en RR. 24 Maart 1695. Voor zooveel niet bepaaldelijk het tegendeel wordt vermeld zijn de aangehaalde brieven en documenten niet in druk uitgegeven.

Dl. 73 . 
Zoo kwam het bij, dat, na de teleurstelling laatstelijk in 1684 en 1685 ondervonden met de scheepsbezending onder Johannes Leeuwenson en de ambassade van Vincent Paets en Louis de Keijser, ${ }^{1}$ de Zeventien in 1689 te rade werden om van alle rechtstreeksche betrekkingen met China geheel af te zien. Uit alle rapporten en brieven, dus berichtten zij aan de Hooge Regeering te Batavia, "nader gebleken zijnde dat de Chineezen niet anders schijnen voor te hebben dan ons door schoone voorgevingen en ijdele beloften maar gaande te houden zonder ons ooit of ooit te doen genieten het effect van een vrijen handel, hebben wij eindelijk geresolveerd na zoo vele vruchtelooze ondernemingen en gedane kosten daarvan af te zien, immers totdat de tijd, hoewel wij ons dat geenszins durven verbeelden, eenige verandering ten goede daarin mocht komen te beloven. Om evenwel (zoo voegen zij er bij) niet t'eenemaal onkundig te blijven van hetgene daar mochte passeeren mitsgaders aan de Engelschen en anderen die vaart en handel niet alleen over te laten, - behalve dat wij op UEd. gedane voorstel de Chineezen en Macaosche Portugeezen met hare waren zeer wel tot Batavia zullen kunnen admitteeren, ook aan ons reserveeren de faculteit om nu en dan, wanneer wij dat zouden mogen komen goed te vinden, mede schip of schepen derwaarts af te zenden verstaan wij dat UEd. zullen vermogen dien handel hetzij ter sluik hetzij opentlijk aan onze Bataviasche ingezetenen vrij en open te laten totdat wij zouden mogen goedvinden anders daaromtrent te disponeeren. En hoewel ons geenszins toeschijnt, dat wij dien vrijdom hierna weder zullen komen in te trekken of dat de tijden haar voor de Compagnie favorabelder zullen komen op te doen als wij die zoo menige jaren ja bijna een eeuw lang hebben gehoopt en verwacht, om de voorschreven ingezetenen echter door die vreeze en bekommering niet te discourageeren of van dien handel af te houden, zullen zij haar daarvan mogen verzekerd houden dat, ingevalle wij namaals daartoe mochten komen te resolveeren, wij haar daarvan tijdelijk, ten minste een jaar te voren, zullen adverteeren.» En, zoo besluiten zij, "door middel van deze vaart zullen wij tot Batavia kunnen debiteeren dezelfde en mogelijk meer waren en koopmanschappen als wij anders met groote kosten en lasten derwaarts

1.Valentijn, Beschrijvinge van Tsjina (IV, 2) blzz. 12, 13. 
hebben moeten voeren, boven de tollen en andere gerechtigheden, die wij daarbij zullen komen te profiteeren ${ }^{1}$.

Dat de hier ontvouwde denkbeelden geheel overeenstemden met die van de Hooge Regeering te Batavia, zien wij uit den brief, dien deze in het voorjaar van 1694 naar het Vaderland zond. $Z \mathrm{ij}$ erkende dat "van over vele jaren door diverse bezendingen ja kostelijke oorlogsexpeditiën » het oogmerk van de Zeventien in China niet bereikt had kunnen worden, maar de "apparentiën om door middel van de te Batavia aankomende Chineesche jonken de uit dat rijk benoodigde goederen machtig te worden", kwamen "hun tegenwoordig alhier zeer favorabel te vertoonen,s zoo schrijft zij. Ook achtte zij de voordeelen, aan deze wijze van negotie verbonden, van groot belang. Immers werden "door de frequentatie van deze plaats door de Chineezen uit dat rijk met hare waren anderen natiën, Compagnies competiteuren zijnde, dezelve onttrokken en van de winsten, die met den aanbreng daarvan hetzij in Europa of andere gewesten hier in Indië daarop te behalen waren, gepriveerd. s Daarenboven zou nu ongetwijfeld de Compagnie "omtrent haren Palembangschen peper, tot welken korrel de Chineezen zoozeer genegen waren en die zij niet wel schenen te kunnen missen, zoo groote sluikerije niet subject wezen, wordende anderszins met geen kleinen ijver hetzelve behartigd om hen daarvan tot Johor en Atjeh hun gerief te doen erlangen, en zulks omdat het haar zoo gemakkelijk alhier te Batavia vergund werd.» Hier kwam nog bij het voordeel, schrijven zij, van «de vermeerdering van 's Compagnies licenten, die van alle de (Chineesche) ware in velerhande soort bestaande tot het minste toe tweevoudig betaald worden, eerst wegens den invoer en daarna weer voor den uitvoer zoo naar de Oostersche provinciën als de geheele Javasche kust, het eiland Sumatra tot Atjeh zelfs en zoo voorts door geheel Indië bijna, gezwegen nog van de hoogere opbrengst van de verpachte stadsbelastingen, welke er bovendien van verwacht mocht worden. ${ }^{2}$

Inderdaad nam onder de nieuwe orde van zaken de Chinasche handel op Batavia alras zulk een goed verloop, dat de Zeventien er hun bijzonder genoegen over te kennen gaven en de Hooge

1 Brief XVII aan GG. en RR. 30 Sept. 1689.

2 Generale missive GG. en RR. aan de XVII 6 Febr. 1694. 
Regeering op het hart drukten alle middelen aan te wenden tot zijn voortzetting en vermeerdering. ${ }^{1}$ Naar alle gedachten zullen de Bataviasche ingezetenen, met name de Europeesche vrijburgers, ofschoon hun volgens de orders uit Patria de vaart op China geheel open en vrij moest worden gelaten, ${ }^{2}$ er weinig of geen deel aan hebben genomen. Het is zoo, Valentijn, die het als tijdgenoot weten kon, verhaalt dat er ook wel tochten naar China zijn gedaan door dezen en genen vrijburger te Batavia ${ }^{3}$ doch het is de vraag of die vergelijkenderwijs van groote beteekenis zijn geweest. Hoe hadden zij trouwens kunnen concurreeren met mededingers, die zoo goedkoop voeren als de Chineesche reeders? Immers wanneer dezen een jonk hadden gekocht en van zeil en treil en drinkwater hadden voorzien, behoefden zij zoo goed als geen onkosten meer te dragen, want de opvarenden bezorgden zelf hun victualie, genoten als gage niets meer dan het recht om vrachtvrij een kleine hoeveelheid goederen mede te nemen, waarmede zij op de plaats van bestemming handel dreven, ${ }^{4}$ en betaalden bovendien nog voor passagegeld een som van tien rijksdaalders de persoon, hetgeen voor de 150 tot 200 koppen, waarmede een jonk gewoonlijk bemand was, een aanzienlijk bedrag uitleverde, en te zamen met al het andere veroorzaakte dat de transportkosten nooit hoog op stok liepen. ${ }^{5}$

Daarentegen verschenen te Batavia geregeld jonken uit Canton, Amoy, Ningpo en andere plaatsen. Zij staken in zee met het doorzetten van den noordermousson in December, wanneer een ieder zich repte om zoo spoedig mogelijk weg te geraken ${ }^{6}$ en kwamen in het allervroegste van het volgende jaar voor Batavia opdagen. Zoodra hun lading aan den wal was gebracht heerschte er in de huis aan huis staande Chineesche winkels, waar alles op het aanlokkelijkst werd uitgestald, een drukte en een vertier, die levendig herinnerden aan de Vaderlandsche kermissen en jaarmarkten ${ }^{7}$ Onder de artikelen, welke de Compagnie van de

1 Brief XVII aan GG. en RR. 7 Sept. 1696.

${ }^{2}$ Zie hiervóo blz. 34.

3 Beschrijvinge van Tsjina (IV, 2) bl. 13.

4 Historische beschrijving der reizen, 's Grav. 1747-1767, IX blz. 98.

${ }^{5}$ Adres van den Raad van Indië Wijbrand Blom aan GG. en RR. 17 Maart 1733.

6 Res. GG. en RR, 9 Maart 1733; Hist. beschrijving der reizen IX blz. 92.

7 Zoo was de toestand ten minste op het laatst van de 18 e eeuw. Vgl. 
Chineesche en Tonkinsche jonken alsook van de met hen meestal in één naam genoemde Portugeesche schepen uit Macao en de Manillavaarders insloeg, nam wat de grootte betrof van de besteedde geldsommen de thee gewoonlijk den voorrang in. Doorgaans werd zij ingekocht.in drie verschillende assortimenten: thee boei, zijnde de ordinairste soort en aldus genoemd naar het Bohea $(\mathrm{Wu}-\mathrm{i})$ gebergte in de provincie Fokien; ${ }^{1}$ thee bing een soort van groene thee $;{ }^{2}$ en "witte» thee. ${ }^{3}$ Daar kwamen bij belangrijke aankoopen van ongemunt goud, Mexikaansche realen, Japansch en Tonkinsch staafkoper, witte Chineesche aluin, ruwe zijde, zijdestoffen, Siamsch sappanhout, een soort zink of alliage van zink dat bekend stond onder den naam van spiauter of tintinago, ${ }^{4}$ en verder, doch tot veel kleinere geldbedragen,

J. P. van Braam, Aanmerkingen en ophelderingen omtrent de particuliere navigatie in Oostindië (Kol. Aanw. nummer 163 Algemeen Rijksarehief). Van Braam's schildering zal echter ook wel voor vroeger tijd gelden.

1 Vgl. Hollingworth, List of the principal tea districts in China etc. in het Journal of the North China Branch of the Royal Asiatic Society, New Series $\mathrm{n}^{\circ} \mathrm{X}$. appendix p. 10 .

2 In de res. GG. en RR. van 2 Maart 1717 ook „keizersthee" geheeten. Vgl. verder Peter Osbeck, Reise nach Ostindien und China, Rostock 1765, S. 297. - Osbeck, een Zweed en discipel van Linnaeus, geboren 1723, vertrok in 1750 naar China als predikant op een schip van de Zweedsche Oostindische Compagnie. Zoowel gedurende zijn verblijf te Canton (Aug. 1751Januari 1752) als op de plaatsen, die hij onderweg aandeed, hield hij zich ijverig bezig met botanische studiën. Hij overleed in 1805 , zie E. Brettschneider, Early European researches into the flora of China, in Journal of the North China Branch of the Royal Asiatic Society 1880 p. 88. Olaf Toreen, de schrijver van de beneden herhaaldelijk aangehaalde Ostindische Reise nach Suratte, China ete. Rostock 1765, bezocht als predikant op het Zweedsche Compagnieschip De Gothische Leeuw, Canton ongeveer tezelfder tijd als Osbeck (Juli 1751-Januari 1752), hij overleed een jaar, na zijn terugkomst in het Vaderland; de brieven, gedurende de reis door hem aan Linnaeus geschreven, zijn naderhand door dezen uitgegeven, Brettschneider, a. w. p. 115.

${ }^{3}$ In de res. GG. en RR. van 22 Januari 1715 wordt de witte thee ook Songlo genoemd. Volgens Hellingworth, t.a.p., die ze Sunglo noemt, was het een soort van groene thee. - Voor nadere bijzonderheden omtrent deze en andere theesoorten (Congo, Hyson) zie o.a. ook Wells Williams, The Chinese commercial guide p. 141. ss.

4 Van Dam, Beschrijvinge van de O. I. Compagnie, Boek II, deel 1, fol. 446, spreekt van "tintinago sijnde spiauter"; Davis, China en de Chineezen, Amst. 1841, III blz. 217, stelt het gelijk met zink; Huisman, La Compagnie d'Ostende, Paris-Bruxelles 1902, p. 106, noemt het een "alliage de zinc, de cuivre et de nickel". 
witte Chineesche was, radix-China, de wortel van een plant die in China en Indië als geneesmiddel werd gebruikt ${ }^{1}$, en porcelein. Hetgeen van den ingeslagen voorraad niet bestemd was om in Indië zelf gesleten te worden, ging in Maart met het zoogenaamde theeschip als retourvracht naar Nederland. ${ }^{2}$ Wederkeerig werden de schippers van de jonken enz. te Batavia van wege de Compagnie geriefd met peper, kaneel, specerijen, vaderlandsche manufacturen, barnsteen, lood, en van tijd tot tijd met grootere en kleinere partijen van sandelhout, benzoin, kaliatoerhout, ${ }^{3}$ bloedkoraal en vogelnestjes. ${ }^{4}$ Bijzonder in trek, tot zoover zelfs dat het leek of zij dien "korrel niet wel konden missen, ${ }^{\mathbf{5}}$ was bij de Chineezen de peper, die in hun land niet alleen evenals in Europa voor het kruiden van de spijzen werd gebruikt maar in de noordelijke provinciën en bij den kleinen man, want de gegoeden bedienden zich daartoe van notenmuskaten, tevens "tot verwarming van de maag met water of andere vochten gedronken werd. ${ }^{6}$ Wijl de toevoer uit Bantam en Palembang, van wier vorsten de Compagnie op grond van de contracten de leveranties wel aanvaarden moest, zoo groot was dat zij er in Indië geen heenkomen mede wisten ${ }^{7}$ zullen GouverneurGeneraal en Raden om zich uit de verlegenheid te redden somtijds bij het bedingen van de peperprijzen allicht wat al te inschikkelijk jegens de Chineesche kooplieden zijn geweest. Zoo althans zagen de Heeren Meesters in Patria het in, door wie de Bataviasche regeering meer dan eens onderhouden werd over de uiterst sobere winsten, welke van den handel in dit product indien al geen schade ten minste zoo goed als geen

1 Vgl. Hirth, Chinesische Studien, S. 89; Wells Williams, The Chinese Commercial Guide; Linsehoten's Itinerario ed. Kern, II blz. 41.

- Valentijn, Beschrijving van Batavia (IV) bl. 260.

3 Kaliatoerhout was een soort van hout, dat uit Coromandel werd aangevoerd, zie Dagregister van Batavia van 1667, blz. 396, Realia, blz. 214.

- De opgaven van de ingekochte en verkochte waren zijn ontleend aan de Generale missives van GG. en RR. aan de XVII 1 Dec. 1703, 30 Nov. 1704, 30 Nov, 1705 , 30 Nov. 1707 , 25 Nov. 1708, 30 Nov. 1709, 29 Nov. 1710, 30 Nov. 1711,25 Nov. 1712, 26 Nov. 1713, 26 Nov. 1714, 28 Nov. 1715, 30 Nov. 1716, 30 Nov. 1717.

${ }^{5}$ Uitdrukking in de Generale missive GG. en RR. aan de XVII 6 Febr. 1694.

6 Antwoord van de Cantonsche factorijbedienden van 25 Dec. 1761 op den brief van de Chinasehe Commissie van 13 Sept. 1763, Resolutie van dezelfden van 17 Sept. 1762.

7 Generale missive GG. en RR. 1 Dec. 1700. 
voordeel overlieten. ${ }^{1}$ Bovendien, zoo schreven zij, bekroop hun de vrees dat de lage verkoopprijzen de Engelschen en andere Europeanen gelegenheid zouden verschaffen om, na den terugkeer van de jonken in China, zich aldaar voor hun retourlading zoo goedkoop van deze waar te voorzien dat de Compagnie buiten staat zou zijn om op de wereldmarkt tegen hen te concurreeren. ${ }^{2}$ Zeker, zij wenschten den Chinaschen handel "gekoesterd en aangehouden" te zien, maar dit mocht niet zoo ver worden getrokken dat het behalen van winst en voordeel, het eenig *oogwit en de ziel der negotie» veronachtzaamd werd en daarom gaven zij de Hooge Regeering order de peper voor niet minder over te laten dan $7 \frac{1}{2}$ rijksdaalder de pikol van $125 \leftrightarrow$ en ze "van langzamerhand, weder indien niet tot 10 voor het minst tot 8 of $8 \frac{1}{2}$ rijksdaalder te doen oprijzen. ${ }^{3}$ Belangrijk, al. stortte zij in de Compagnieskas geenszins de tonnen schats, door de Chineezen betaald voor de reusachtige hoeveelheden peper welke zij wegsleepten, was ook de verkoop van kaneel, die men naar het schijnt vooral omzette aan de Manillavaarders. ${ }^{4}$ Alles te zamen genomen gingen er weinig jaren voorbij waarin de gezamenlijke opbrengst van de waren, aan de Chineesche jonken, de Portugeezen van Macao en de Manillavaarders door de Compagnie verkocht, het bedrag van den inkoop niet met één à vijf ton overtrof. ${ }^{5}$

1 Brief XVII aan GG. en RR. 18 Febr. 1702.

${ }^{2}$ Brieven XVII aan GG. en RR. 18 Febr. 1702, 21 Juni 1702 en 9 Juli 1715.

s Brief XVII aan GG. en RR. 18 Febr. 1702. Bij hun brief van 9 Juli 1715 gaven zij order den prijs, die laatstelijk bij de openbare veiling $9 \frac{1}{2}$ rijksdaalder had bedragen, op 10 rijksdaalders te stellen.

- De Generale missives van GG. en RR. aan de XVII van 30 Nov. 1704 en 30 Nov. 1705 vermelden bepaaldelijk dat zij verkocht is aan jonken, die over Manilla terug reisden, die van 26 Nov. 1713 dat zij is verkocht, aan de Manillavaarders", terwijl in den brief van 18 Febr. 1715 door GG. en RR. de vrees wordt uitgesproken, dat zij met de van Ceilon geëischte kaneel zullen blijven zitten, daar men, uit de Manilla nog niemand "vernomen" heeft". In 1766 was de toestand nog precies eender:, de handel van Manilhas eindelijk is ook een voornaam artikel, dat men moet zoeken te maintineeren door haar bij ons te lokken, waardoor de Compagnie een goede partij kaneel afzet," zegt J. C. Rademaker in zijn „Bedenkingen over den tegenwoordigen staat der Nederl. O. l. Maatschappij" aangeboden aan Thomas Hope 5 Juni 1766 (Kol. Arch. n ${ }^{\circ}$ 8407)"'.

${ }^{5}$ Blijkens de opgaven, voorkomende in de Generale missives GG. en RR. aan de XVII 1 Dec. 1703, 25 Nov. 1708, 30 Nov. 1709, 29 Nov. 1710, 30 Nov. 1711,25 Nov. 1712 , 26 Nov. 1713,26 Nov. 1714,28 Nov. 1715 , 30 Nov. 1716,30 Nov, 1717. 
Als schaduwzijde stond hier tegenover dat van de bemanning van de jonken dikwijls velen op Batavia achterbleven, die in het ronde als vagebonden bleven rondzwerven en een groot gevaar opleverden voor de openbare rust en veiligheid. Teneinde dit euvel te keer te gaan had de Hooge Regeering zich reeds in 1690 genoodzaakt gevonden een verordening uit te vaardigen waarbij aan alle Chineezen, met jonken en andere schepen uit China, Tonkin, Quinam d. i. Cochin-China en Kambodja te Batavia overkomende, de verplichting werd opgelegd om weer met diezelfde vaartuigen terug te keeren, op straffe van zoolang in den ketting te worden geklonken totdat de in het volgende jaar verschijnende jonken weder de thuisreis zouden aannemen, met bedreiging dat een schipper, die meer volk aanbracht dan tot het bestier van zijn jonk van noode was, in een boete zou worden geslagen van 60 stuiver de man. ${ }^{1}$ Daar het misbruik niettemin voortduurde, gingen Gouverneur-Generaal en Raden in 1706 nog iets verder door aan het plakaat de bepaling toe te voegen, dat elk Chineesch vaartuig slechts een bepaald getal "nieuwelingen uit China mocht medebrengen, de groote niet boven de 100 , de kleine niet meer dan 80 koppen, en dat voor elk man meer, die er onder de opvarenden van zijn bodem werd aangetroffen, de schipper een boete beloopen zou van 10 rijksdaalders. ${ }^{2}$ Doch in spijt van alle plakaten en verordeningen bleef het kwaad maar aldoor voortwoekeren, want niettegenstaande pas in 1716 verscheidene jonkschippers wegens overtreding waren beboet, hadden het volgende jaar sommigen wel twee- ja driemaal zooveel opvarenden aan boord als het voorgeschreven getal toeliet. ${ }^{3}$ Zoo bracht in Maart 1717 een "anachoda» ${ }^{\text {van }}$ Canton met een kleine chaloup, gelijk Gouverneur-Generaal en Raden het uitdrukken, "wel 150 geschoren Chineesche nieuwelingen aan in plaatse van 80 gelijke kaalooren, die hem naar de order dezer regeeringe op het allerhoogste maar gepermitteerd konden zijn geweest. ${ }^{5}$ Het

1 Plakaat van GG. en RR. 21/29 Mei 1690, v. d. Chijs, Nederl. Indisch plakaatboek III, blz. 262 .

2 Res. GG. en RR. 28 Mei 1706.

${ }^{3}$ Plakaat van GG. en RR. van 20 April/4 Mei 1717, v. d. Chijs a. w., IV blz. 97 .

4 Schipper, zie Hobson-Jobson, A glossary of Anglo-Indian colloquial words and phrases, London 1903, i v. nacoda.

${ }^{5}$ Res, GG. en RR. 19 Maart 1717. 
gevolg was dat Gouverneur-Generaal en Raden voor de delinquenten niet alleen een verhoogde boete van 15 rijksdaalders vaststelden, maar tegelijkertijd verordenden dat zij daarenboven nog met zoodanige arbitraire correctie zouden worden gestraft als zij, de Hooge Regeering zelve, of wel de rechter mocht goedvinden; dat zij hun te veel aangebrachte manschappen "te zamen bij den anderen moesten houden» om ze weder naar hun land terug te voeren, en dat geen Chineesch schipper met minder volk mocht vertrekken dan waarmede hij gekomen was. ${ }^{1}$

Afgezien van de stoornis, aan zulke.bedrijven onvermijdelijk verbonden, en den hinder door rondzwalkende zeeroovers onderweg aan de jonken berokkend, ${ }^{2}$ heeft de vaart van China op Batavia zoo het schijnt rustig haar gang kunnen gaan tot het jaar 1718 , toen zij voor eenige jaren lang ten eenenmale stop werd gezet.

Indien wij Valentijn mogen gelooven lag de schuld hiervan uitsluitend aan de winzucht der Hooge Regeering. Volgens zijn zeggen vond deze in Maart 1717 goed om de met de jonken aangekomen Chineezen te dwingen het pikol thee, dat zij naar zij verklaarden wegens hun zware lasten van bodemerij voor niet minder dan 60 rijksdaalders konden geven, aan de Compagnie over te laten voor den vroegeren prijs van 40 rijksdaalders, of dat zij anders geen last zouden mogen breken. Daar dit laatste, schrijft hij, hun nog grootere schade zou hebben veroorzaakt, kozen zij van twee kwaden het minste en stonden de thee tegen den geboden prijs af, maar zwoeren tegelijkertijd dat er nooit geen jonken "meer op Batavia komen zouden, behalve dat ook de keizer van China hierover zoo vertoornd was, dat hij 's jaars daaraan alle de Chineezen, zijn onderdanen en geen vaste ingezetenen van Batavia zijnde, op straffe van hunne vrouwen, kinderen en alle hunne vrienden tot slaven te maken, naar China opriep. ${ }^{3}$ Dat Gouverneur-Generaal en Raden werkelijk een diergelijk besluit hebben genomen, lijdt geen twijfel.

1 Plakaat van 20 April/4 Mei 1717.

2 Blijkens Generale missive GG. en RR. aan de XVII 1 Dec. 1700 hadden zij toen op verzoek van de Chineesche officieren te Batavia, evenals in Nov. 1697, het vaarwater om de Noord, daar de jonken passeeren moesten, door een paar Compagnieschepen laten beveiligen tegen een Engelschen roover, die zich daar volgens ingekomen berichten onthield.

s Valentijn, IV (Beschrijving van Groot Java) blz. 348. 
Aangezien "de tijd tegenwoordig reeds veel te verre is ingeschoten," zoo leest men in hun resolutie van 2 Maart 1717 , "om dien nog verder met de talmachtige Chineezen te laten verloopen, (is) noodig geacht en besloten tot afsnijdinge van alle verdere hacquetten ${ }^{1}$ de prijzen te reguleeren en bepalen als volgt, t. w. de thee songlau of ordinaire groene thee op 40 rijksdaalders het pikol van $125 \mathbb{R}$, de thee bing of zoogenaamde keizersthee op 60 rijksdaalders het gelijke picol, de thee boei van de eerste soort kanhoe op 80 rijksdaalders en de mindere soorten naar advenant haar deugd en waarde, wordende geoordeeld dat zij daarmede rijkelijk zullen kunnen bestaan, en dat dienvolgens geen reden zullen hebben daarover onvergenoegd te wezen, doch echter diegenen, die niet genegen zouden mogen zijn hare thee voor de gedachte prijzen af te staan, dezelve niet af te dwingen maar te laten behouden, mits dat dezelve in dien gevalle hier ter plaatse niet verhandeld maar naar China teruggevoerd zal moeten worden. ${ }^{2}$ Voor het overige echter wijkt de voorstelling van het gebeurde door Gouverneur-Generaal en Raden gegeven, van die van Valentijn aanmerkelijk af. Er zijn hier, aldus berichten zij op het laatst van 1717 aan de Zeventien, in het geheele jaar 14 stuks Chineesche schepen aan geweest "zijnde al meest conform voorgaande jaren, maar of het getal de aanstaande reis wel zoo groot zal zijn wordt getwijfeld, en bij sommigen onder die natie gemeend van neen en dat de vaart naar buiten ter oorzake van de hooge jaren des keizers geheel eng zou worden bepaald, om te minder gelegenheid te laten tot woelingen ten nadeele van het rijk, waarmede men al eenige jaren gerucht heeft dat het in opzichte der inwendige ruste niet al te zeker zoude zijn gesteld geweest. ${ }^{3}$ In hun brief van Maart 1718 laten zij er op volgen dat inderdaad de keizer zijn onderdanen bij plakaat verboden had naar andere gewesten buitenslands te varen behalve alleen naar Japan. ${ }^{4}$

Wie van hen beiden de toedracht van het gebeurde naar waarheid moge hebben weergegeven, over de nadeelen, die er

1 Kibbelarijen, geharrewar, zie het Groot Woordenboek der Nederl. taal i. v. hakketeeren.

2 Res. GG. en RR. 2 Maart 1717.

3 Generale missive GG. en RR. aan de XVII 30 Nov. 1717.

4 Generale missive GG. en RR. aan de XVII 20 Maart 1718. In hun resolutie van 3 Mei 1718 stant dat speciaal de vaart op Batavia verboden was. 
uit voortsproten, dachten Valentijn en de Hooge Regeering volmaakt eenstemmig. Valentijn achtte ze "ongeloofelijk groot»" en ook naar het oordeel van de laatste was de staking van de Chinasche vaart uiterst schadelijk niet enkel voor de Compagnie maar tegelijk voor de stad Batavia en haar inwoners. Immers de Compagnie, vreesde zij, zou thans niet meer zoo gemakkelijk de thee en andere Chineesche waren kunnen inkoopen terwijl wederkeerig de omzet aan de Chineezen zou ophouden van de Vaderlandsche manufacturen, peper, specerijen en andere koopmanschappen, welke haar jaarlijks fraaie winsten hadden opgeleverd; de Bataviasche particulieren zouden de profijten en het gerief moeten derven, tot dusver door hen genoten van den aanbreng en het vertier van allerlei Chineesche kleinigheden en kramerijen; en eindelijk zou de stad Batavia gevoelig worden getroffen in haar pachten en inkomsten. ${ }^{2}$

Geen wonder dat bij de Hooge Regeering de vraag oprees, of men niet van Compagnie's wege zelf een scheepsbezending naar China behoorde te doen. In haar vergadering van 3 Mei 1718, waar dit onderwerp op het tapijt kwam, erkende men dat het oppervlakkig beschouwd wel het naast voor de hand lag "om nevens de Engelschen, Franschen en andere negotianten derwaarts te equipeeren en van daar te halen datgene dat de Edele Compagnie van thee en andere waren uit dat rijk tot haren handel noodig had, en alzoo de voordeelen daarvan aan andere Europeanen alleen niet te laten.» Doch aan zulk een onderneming stonden zware hinderpalen in den weg, oordeelde de vergadering. Allereerst de groote kosten, die er aan verknocht waren, en de onzekerheid hoe de Chineesche machthebbers de onzen zouden ontvangen. Want wie kon zeggen of zij de Compagnieschepen "op deze en gene pretexten, die juist niet zoo licht te raden als door haar uit te vinden waren - al was het maar onder bedreiginge van ons te noodzaken hare onder 's Compagnie's jurisdictie gezeten onderdanen, die bij het verbod der vaart waren ingedaagd, naar hun land te doen keeren niet wel zouden beslaan en bekommeren met arresten of zware geldboeten?» Gezwegen nog van thare gewone dwingelandijen en vexatiën in den handel, die de Compagnie voorheen daar

1 t. a. p.

'Generale missive GG. en RR. aan de XVII 20 Maart 1718. 
te lande had ondervonden en die beide de regeering in het Vaderland en die in Indië indertijd bewogen hadden de vaart derwaarts op te geven en in plaats daarvan de Chineezen met hun jonken naar Batavia te trekken. Daarom werd de vraag geopperd of het geen aanbeveling verdiende vooralsnog geen schepen aan zoodanig gevaar bloot te stellen, maar nader af te wachten "waarhenen zich dat werk zou willen wenden," te eerder daar men "middelerwijl de gelegenheid had om de Compagnie de benoodigde thee te doen toebrengen en bezorgen door de Portugeezen van Macao, zooals dezen jare is geschied met ruim de helft van den Vaderlandschen eisch ${ }^{1}$ en voor het geheel wel ware te doen geweest, ingevalle de laatst aangekomen twee scheepjes maar een maand vroeger alhier waren komen opdagen.» Het een en het ander in aanmerking nemende nam de vergadering ten slotte eenparig het besluit om, in afwachting van hetgeen de tijd kwam te leeren en van de beslissing der Heeren Meesters op dit stuk, dit jaar geen schepen naar China uit te zenden, maar bij de hoofden van de Macaosche vaartuigen aan te dringen op een vroegere verschijning te Batavia en hun tevens een opgaaf te verstrekken van de hoeveelheid van elke soort thee, die de Compagnie ingevolge den jongst ontvangen Vaderlandschen eisch behoefde, teneinde zoodoende van den aanvoer des te beter verzekerd te zijn en het theeschip ${ }^{2}$ op zijn tijd naar Nederland te kunnen afzenden. ${ }^{3}$

Al even weinig bleek de Hooge Regeering gezind te zijn tot het aanmoedigen van eenige particuliere vaart op China: in 1718 weigerde zij zelfs aan enkele Bataviasche ingezetenen het door hen aangevraagde verlof om een uitrusting daarheen te doen. ${ }^{4}$ Op het eerste gezicht lijkt die houding vreemd genoeg. Wat toch, zou men zoo zeggen, wat bezwaar konden GouverneurGeneraal en Raden hebben tegen zulke particuliere ondernemingen die, nu de Compagnie zelf zich met de vaart op China niet inliet, haar niet konden schaden, integendeel haar veeleer voordeel beloofden daar zij het monopolie verbraken van de Macaosche Portugeezen, welke thans van de Chinasche vaart

1 De jaarlijksche bestellíng voor Nederland.

${ }^{2}$ De gewone tijd van vertrek viel in Maart, zie Valentijn, IV (Beschrijvinge van Batavia) blz. 260.

${ }^{3}$ Res. GG. en KR. 3 Mei 1718.

4 Als roren, en Generale missive GG. en RR. aan de XVII 6 Dec. 1718, 
geheel meester waren? Het antwoord op deze vraag vinden wij opgeteekend in hun Decemberbrief van 1718. Zij wachtten nog steeds af, heet het daar, of de Chineezen voor wie 's keizers verbod toch ook uitermate nadeelig was hier geen verandering in zouden trachten te bewerken. Van dit gevoelen, meldden zij er bij, waren insgelijks geweest de hoofdofficieren van de Chineesche kolonie ten hunnent, die zelfs zoover waren gegaan van aan te raden dat aan niemand van de Bataviasche ingezetenen toegestaan werd "naar China te equipeeren om de regenten" daar te lande "de gelegenheid niet te geven om daartegen moeilijkheden te maken en ons alzoo met haar in verschillen te wikkelen, gelijk cok daarop aan niemand consent is verleend derwaarts te equipeeren. ${ }^{1}$

Gelijk men denken kan, verdroot het wegblijven van de Chineesche koopvaarders de Bewindhebbers in Nederland in geen mindere mate dan de Indische regeering zelf. "Het ware zeer te wenschen geweest» zoo gaven zij deze te kennen, "dat men de negotie met de Chineezen op Batavia had kunnen continueeren»: Gouverneur-Generaal en Raden behoorden dus huns inziens geen middelen te verzuimen om ze wederom naar die haven te lokken, bijvoorbeeld met een vermindering van deze of gene belasting of wel door de Vaderlandsche manufacturen ten goedkoopste aan hen over te doen, desnoods tegen zoo lagen prijs dat er genoegzaam geen winst op overschoot. Alleen moest er zorg worden gedragen, dus verordenden zij, dat er op Batavia "niet te veel van die natie hun verblijf kwamen te houden, » en inzonderheid dat men de peper en specerijen niet beneden de vastgestelde minimumprijzen aan hen afstond, "om te voorkomen dat de Europeeërs met dezelve uit handen van de Chineezen te koopen zoodanig voordeel zouden kunnen behalen, dat zij daarop hare vaart op Indië konden goedmaken.» Ten aanzien van een bezending naar China voor Compagnie's eigen rekening waren de Bewindhebbers een ander gevoelen toegedaan dan de Hooge Regeering: indien de pogingen om de Chineezen tot hervatting van de vaart op Batavia te bewegen faalden, zou men huns erachtens te bekwamer tijd een of twee schepen kunnen uitrusten om in dat rijk een hoeveelheid thee "en zoodanige andere koopmanschappen in te

1 Generale missive GG. en RR. 6 Dec. 1718. 
koopen, als waarmede de tegenwoordige Europeesche avonturiers ${ }^{1}$ hare reize kwamen goed te maken, employeerende te dien einde de Vaderlandsche manufacturen, de peper, specerijen en zilveren muntspeciën, die 's Compagnie's wege beter kunnen worden aangebracht als door eenige anderen.s Kon dit echter voorshands niet worden ondernomen, zoo werden Gouverneur-Generaal en Raden gemachtigd om ondertusschen de Macaosvaarders te animeeren tot den aanbreng van thee en zoodanige Chineesche waren, waartegens men voormaals Compagnie's koopmanschappen en contanten aan de Chineezen had omgezet., ${ }^{2}$

Bij slot van rekening evenwel zijn in de eerstvolgende jaren de jonken maar aldoor achterwege gebleven en GouverneurGeneraal en Raden genoodzaakt geweest hun gerief van thee enz. bij de overkomende Macaovaarders te zoeken. Want van het openen eener eigen vaart op China, hoe sterk er van uit Patria op mocht worden aangedrongen, ${ }^{3}$ bleven zij zoo af keerig als te voren; ${ }^{*}$ de kans, dat de hoogbejaarde keizer van China mogelijk binnenkort door een ander werd vervangen, "die de zaak mocht begrijpen onder een gansch andere gedaante, de winsten, welke de regenten van de kuststreken van het rijk zelf van de vaart der jonken plachten te genieten, het een en het ander gaf hun, naar zij in 1721 aan de Zeventien mededeelden, hoop dat de Chineesche schippers vroeger of later wel hun tochten naar Batavia zouden hervatten. Ongelukkigerwijs, voegen $z \mathrm{ij}$ er $\mathrm{bij}$, worden volgens de geruchten de regenten « in dat concept aan het Hof bijzonder gedwarsboomd door de heimelijke instigatiëı der Portugeesche papen, en anderen uit den senaat van Macao, die haar werk maken den keizer te doen begrijpen het nadeel en het gevaar, twelk voor zijn onderdanen is opgesloten in de vaart ter zee, opdat zijlieden door deze kunstgreep in possessie van die vaart alleen en met seclusie van andere Chineesche ingezetenen zouden kunnen continueeren en blijven, want zij profiteeren goede sommen door de vracht. ${ }^{5}$

${ }^{1}$ Bedoeld zijn voornamelijk de Chinavaarders uit de Zuidelijke Nederlanden, de voorloopers der latere Compagnie van Ostende.

2 Brief XVII aan GG. en RR. 28 Sept. 1719.

3 Brief XVII aan GG. en RR. 30 Juli 1721.

4 Generale missives GG. en RR. aan XVII 30 Nov. 1720, 30 Nov. 1721, 30 Nov. 1722.

5 Generale missive GG. en RR. aan de XVII 30 Nov. 1721. Blijkens resol. GG. en RR. 9 Maart 1733 voeren de Portugeezen naar Batavia „meest maar 
En te Batavia makkten zij het weinig beter, de Portugeezen van Macao. $\mathrm{Zij}$ "seduceerden en vervoerden de beste lijfeigenen, " en "verleidden er de inwoonderen en (Compagnies) dienaren" zoowel "tot het paapsche bijgeloof" als tot het stelen van de specerijen en dergelijke. Maar men had nu eenmaal geen keus, verklaren Gouverneur-Generaal en Raden ergens, men moest zich goedschiks kwaadschiks met die Portugeezen behelpen en hun nog een "semblant van vriendschap" toonen op den koop toe, zeggen zij. ${ }^{1}$

Toen zij dit laatste naar het Vaderland overbriefden begon echter de horizon al eenigermate op te klaren. In Maart 1722 konden zij aan de Zeventien de heugelijke tijding toezenden, dat er weder eenige Chineesche jonken waren opgedaagd, twee uit Shanghai en drie uit Tonkin, naar luid van de berichten door hen medegebracht de voorloopers van nog twee tot drie meer, die straks van andere, plaatsen stonden te arriveeren. ${ }^{2}$ Zoo herleefde hoe langer hoe meer de hoop op een heropening van de vaart tusschen China en Batavia op den ouden voet, ten voordeele van Compagnie en gemeente beide, welke in dat geval de Macaosche vrachtscheepjes links konden laten liggen voor de jonken, waar men veel voordeeliger placht te recht te komen. ${ }^{3}$ De eer van deze gunstige wending van zaken wordt toegekend aan het beleidvol optreden van den Gouverneur-Generaal Zwaardekroon. ${ }^{*}$ Waarschijnlijk heeft Zwaardekroon daarbij den krachtigen steun ondervonden van «diverse kooplieden» - blijkbaar behoorende tot de Chineesche kolonie op Batavia - , door wie, omdat hun geldelijk belang er evenzeer mede gemoeid was als dat van de Compagnie en de Bataviasche burgerij, in China zelf "middelen werden aangelegd» om afschaffing van

op vracht voor de Chineezen." Hetzelfde wordt ook met zooveel woorden gezegd in de Generale missive GG. en RR. aan de XVII 30 Nov, 1722.

1 Brief GG. en RR. aan de XVII 31 Maart 1722.

2 Onder het schrijven dezes, zeggen zij eenige bladzijden verder, is het getal al aangegroeid tot zes, Brief als voren.

${ }^{3}$ Als voren. Ook Valentijn, IV, 2 (Beschrijvinge van Tsjina) blz. 13 verhaalt dat de Chineezen hun goederen veel goedkooper overlieten dan de Macauwers. Elders (IV Beschr. van Groot Java blz. 348) zegt hij dat de onzen ze van hen wel eens zoo duur moesten koopen als van de Chineesche schippers.

4 Du Bois, Vies des Gouverneurs-Généraux, La Haye 1763, p. 297. 
het vaartverbod te verkrijgen. ' Wat hiervan zij, door de wederverschijning van de jonken was de handelsverbinding met China weer aangeknoopt en een tijdperk van nieuw leven voor Compagnie's negotie op dat rijk ingeluid.

Kwamen er in de jaren onmiddellijk voorafgaande aan het vaartverbod gewoonlijk ieder voorjaar twaalf tot zestien jonken te Batavia aan, ${ }^{2}$ in 1723 vertoonden er zich niet minder dan een-en-twintig, in 1724 achttien. ${ }^{3}$ Met de drukke scheepsbeweging hielden de belangrijke inkoopen en omzetten der Compagnie gelijken tred. Wat de eerste betreft, zij bestonden als van ouds in thee, ruwe Chineesche zijde en zijdestoffen, ongemunt goud dat ter sluik uit China werd aangebracht, ${ }^{+}$ spiauter, aluin, Tonkinsch koper, radix China, benevens enkele koopmanschappen, welke de Compagnie vroeger van de jonken niet placht in te slaan, ${ }^{5}$ zooals gomlak op stokjes, parelmoerschelpen, kwikzilver, aguilhout, sandelhout, radix galinga (galagawortel) een drogerij die veel als geneesmiddel maar ook bij het brouwen van bier en in de keuken werd gebruikt ${ }^{6}$ enz. ${ }^{7}$.

De artikelen, door de Compagnie aan de jonken verkocht, bepaalden zich in hoofdzaak tot peper, lood, notemuskaten, nagelen, nagelolie, kaneel, Vaderlandsche manufacturen, barnsteen, bloedkoraal, kaliatoerhout, benzoin, kamfer, Nederlandsche en Mexikaansche zilveren muntstukken, staafzilver, gesmolten zilver van gesnoeide munt, en sedert 1724

1 Generale missive GG. en RR. aan de XVII 30 Nov. 1722. Natuurlijk zal ook het feit van invloed zijn geweest, dat er omstreeks dezen tijd een nieuwe keizer in China aan de regeering kwam; den 20 December 1722 overleed nl. keizer Kang-hi, die sedert 1661 geregeerd had, vgl. J. Tobar, Tableau cbronologique de la dynastie de la Grande Pureté (Journal of the China Branch of the Royal Asiatic Society Vol. XXXIII n 2 2. 1899/1900).

${ }^{2}$ Blijkens de brieven GG. en RR. aan de XVII 25 Nov. 1712, 26 Nov. 1713, 26 Nov. 1714, 18 Febr. 1715 , 30 Nov. 1716, 30 Nov. 1717.

${ }^{3}$ Blijkens de brieven GG. en RR. aan de XVII 21 Sept. 1723, 30 Nov. 1724.

4 Het mocht nl. niet uit China worden uitgevoerd, Lockyer, Beschrijving van den koophandel in Oost-Indiën (omstreeks 1711), Amst. 1753 blz. 77, Dagregister van de Cantonsche Carga's 30 Dec. 1731.

${ }^{5}$ Er blijkt ten minste in de opgaven van het ingekochte over 1703-1717 (voorkomende meestal in de Generale najaarsmissives) niets van.

${ }^{6}$ Vgl. Hirth, Chinesische Studien, S. 87.

7 Blijkens brieven GG. en RR. aan de XVII 30 Nov. 1722, 3 Dec. 1723, 30 Nov. 1724,30 Nov. 1725,5 Dec. 1726,30 Nov. 1727, 8 Dec. 1728, 30 Nov. 1729. 
ook in Bankatin ${ }^{1}$. Welk een omvang de handel aannam bewijzen de sommen die jaarlijks ten bedrage van ruim twee tot viermaal honderdduizend rijksdaalders van den verkoop werden gemaakt en, een paar jaren uitgezonderd waarin voor meer ingekocht dan omgezet werd, de inkoopen met 95.000 tot 200.000 rijksdaalders te boven gingen. ${ }^{2}$

Onder al deze bedrijven waren er in Europa voor de Compagnie nieuwe mededingers ten tooneele verschenen, welke den bloei van haar negotie in Chineesche retourwaren op het ernstigst bedreigden. Sinds 1714 en 1715 begonnen namelijk vers heidene kooplieden in de Oostenrijksche Nederlanden schepen uit te rusten om van uit Ostende handelstochten te doen naar het tegenwoordige Britsch-Indië en China.

Een hunner, een voormalig bankier te Amsterdam, zekere P. J. Cloots, die evenals vele andere vreemdelingen, Engelsche Jacobieten en Nederlandsche Roomsch-Katholieken, door deze ondernemingen naar België was gelokt en zich daar had laten naturaliseeren, zond in Januari 1718 een schip naar Canton in China. Na een reis van anderhalf jaar viel deze bodem, de eerste Belgische die ooit het Hemelsche Rijk bezocht, weer de haven van Ostende binnen met een rijke lading, waarvan alleen de aangevoerde thee bij de veiling ongeveer een millioen gulden opbracht. Aangemoedigd door dit succes en de bescherming, hun van wege den Chineeschen keizer toegezegd, volgden andere schepen in het gebaande spoor, zoodat mettertijd tusschen Ostende en Canton een levendige vaart onstond, even voordeelig voor de Belgen, wien zij rijke winsten in den schoot wierp, als schadelijk voor de Nederlandsche Compagnie, die er een goed deel van de hare door kwam te derven. Dreigender nog werd het gevaar toen de Belgen in 1722, het voorbeeld van andere natiën volgend, zich tot een Compagnie vereenigden door hun toenmaligen souverein Keizer Karel VI van het recht voorzien om, met uitsluiting van alle andere ingezetenen van de Oostenrijksche Nederlanden, handel te drijven op Oost- en West-Indië en de kusten van Afrika.

Van meet af aan waren de onzen dan ook volijverig in de weer om met alle mogelijke middelen de Ostendenaren uit het

1 Blijkens als voren.

2 Blijkens als voren.

Dl. 73 
vaarwater te verdrijven. Ten einde het aanwerven van zeevolk hier te lande te beletten - de Vlamingen en Brabanders konden namelijk voor hun Indische vaart de hulp van Nederlandsche en Engelsche matrozen niet ontberen - vernieuwden de StatenGeneraal in 1717 het van ouds geldende verbod, dat geen onderdanen van de Republiek in vreemden dienst op OostIndië mochten varen. Wie reeds dienst hadden genomen, zoo werd verordend, moesten binnen drie maanden tijds in hun woonplaatsen terugkeeren en zouden in dat geval "impuniteit" genieten, hen die dit nalieten wachtte eeuwige verbanning en confiscatie van goederen; de andere overtreders zouden, hier of in Indië aan boord van vreemde Oostinjevaarders aangetroffen wordende, hun vergrijp met den dood moeten bekoopen. Geen Nederlander zou, op verbeurte telkens van het viervoud van den inleg, deel mogen nemen aan buitenslands op het touw gezette handelsondernemingen naar Indië, en evenmin zich door vreemden als "factoor of commissaris" laten gebruiken om te hunnen behoeve varend volk in dienst te nemen dan wel de door hen uit Oost-Indië overgebrachte koopmanschappen binnen de Republiek in commissie te ontvangen of te verhandelen, op straffe van verbeurdverklaring dezer goederen, 1000 gulden boete en arbitraire correctie. ${ }^{1}$ Toen met dat al aan het licht kwam, dat de Ostendenaren hun wervingen ten onzent lieten voortzetten en vele ingezetenen "uit een vuile baatzuchtigheid» bij hen bleven dienst nemen, kondigden de Staten-Generaal in 1723 een nieuw plakaat af, waarbij zulke wervers werden bedreigd met openbare geeseling en altoosdurend bannissement, terwijl alle Nederlanders, die bereids dienst bij de Ostendenaren hadden genomen, gewaarschuwd werden dat zij, zoo zij binnen twee maanden tijds in het land terugkeerden, van straf vrijgesteld maar anders tot eeuwige verbanning en confiscatie van goederen verwezen zouden worden, en dat hun, ingeval zij òf hier òf in Indië werden aangehouden op Ostendische schepen, de doodstraf stond te wachten. Om te voorkomen dat de Ostendenaren zich hier te lande, zooals zij blijkbaar meermalen hebben gedaan, ${ }^{2}$ voor hun Indische vaart van schepen voorzagen, werd bepaald dat,

1 Plakaat Staten-Generaal 21 Sept. 1717, Groot Plakaatboek, V fol. 1534.

${ }^{2}$ Zie de opgaven bij Huisman, La Compagnie d'Ostende, p. 87. Mertens, La Compagnie d'Ostende in Bulletin de la Société de Géographie d'Anvers, VI (188I) p. 414. 
wanneer deze of gene Nederlander in commissie schepen voor hen inhuurde, aankocht of uitrustte, de schepen met al wat zij inhadden ten bate van de Nederlandsche Oost-Indische Compagnie zouden worden verbeurd verklaard, en dat hij bovendien zou beboet worden met een geldsom viermaal zoo hoog als de waarde van het geconfiskeerde schip met toebehooren. Ook, aldus hield het plakaat verder in, mocht niemand in de Indische vaart van de Ostendenaren geld steken of op eenigerlei wijze participeeren; wie zich daaraan schuldig maakte zou telken reize verbeuren het viervoud van zijn ingelegde gelden en, werd hij ten tweeden male bekeurd, voor eerloos en infaam worden verklaard. Geen makelaars of wie ook waren gerechtigd gelegenheid te verschaffen om op de Ostendische actiën in te teekenen, wat niet belette dat toen in Aug. 1723 de inschrijving werd opengesteld verscheidene Nederlanders op de Ostendische actiën inteekenden. ' $\mathrm{Zij}$ mochten ze evenmin verhandelen en "ook geen wissels, bodemerijen of assurantien ${ }^{2}$ te (hunnen) laste of behoeve of wel op schepen of goederen hun toebehoorende * verhandelen of disconteeren, gelijk ook aan alle anderen verboden werd "zoodanige wissels of bodemerijen te trekken, te verhandelen, disconteeren, accepteeren of te voldoen mitsgaders eenige assurantiën of bodemerijen op de bovengemelde schepen of goederen, gaande of komende van of naar de Indiën uit of naar de Oostenrijksche Nederlanden, te teekenen op poene dat de makelaars van hun ambt zouden worden gepriveerd en bovendien verbeuren een boete van 1000 gulden» zoo dikwijls zij zich tot dat werk hadden laten gebruiken. Eindelijk zou het viervoudig bedrag van zoodanige actiën, wisselbrieven, bodemerijen en assurantiën als boete worden opgelegd aan een iegelijk, die ze kocht, verkocht, trok, accepteerde, disconteerde of voldeed, en zou op geen "aanteekeningen, acten en instrumenten, uit al zulke ongeoorloofde handelinge spruitende, tusschen partijen en contrahenten ) recht mogen geschieden. ${ }^{3}$

Ondertusschen had de Compagnie, door wier invloed natuurlijk

I Vgl. Wagenaar, Vaderl. historie, XVIII blz. 280 en Huisman, a. w. p. 240.

${ }^{2}$ Het verbod van zulke assurantiën was voor de Ostendenaren des te hinderlijker, omdat er in België geen maatschappijen voor zeeverzekering bestonden; de eerste, die te Antwerpen is opgericht, dateert pas van 1754, Huisman, a. w. p. 136; Mertens, a. w. p. 391.

s Plakaat Staten-Generaal 19 Juni 1723, Groot Plakaatboek, VI fol. 1390. 
die plakaten van de Staten-Generaal waren uitgelokt, van haar kant den strijd overgebracht op economisch terrein. Koopt, op dezen zin liepen de orders van de Zeventien aan de Hooge Regeering in Indië, koopt te Batavia de thee op tot een "ongelimiteerde quantiteit, zoover de voor het Vaderland beschikbare scheepsruimte maar toelaat, zendt van die waar en de andere Chineesche koopmanschappen, die wij noodig hebben, zooveel herwaarts als voor een tijd doenlijk is, laat ze zelf met een of twee Compagnieschepen uit China afhalen, want wij zijn vastbesloten onze mededingers niet in het allerminste toe te geven maar integendeel die Chineesche goederen in zulk een overvloed op de Europeesche markt te werpen, al ware het dat de Compagnie er voorshands weinig winst op maken kon, dat de schade hun door de sterke daling van de prijzen toegebracht ze van zelf nopen zal hun handel op te geven. ${ }^{1}$ Tegelijkertijd liet men van uit Batavia door tusschenkomst van de Portugeezen van Macao de inkoopprijzen te Canton opjagen zooveel men maar kon. ${ }^{2}$ Welhaast geraakte nu, ten deele ook door den ruimen aanbreng van de Engelschen en van de Ostendenaren zelve, de markt in Europa zoodanig met thee overvoerd en liepen de verkoupprijzen zoo geweldig achteruit dat men het artikel omstreeks 1721 te Amsterdam met kruiwagens langs de straat zag uitventen. ${ }^{3}$

Hoe men hun bezuiden den Evenaar nog op andere wijze den voet zocht dwars te zetten, ondervonden eenige Ostendische schepen in de jaren 1717-1719. Een hunner, in September 1717 ter reede van Batavia aangeland, was destijds op verzoek van den kapitein, die de wil had naar Macao zoo hij zeide, aldaar van verversching, water, en brandhout voorzien wijl de Hooge Regeering het op grond van zijn Portugeeschen pas voor een Portugeesch vaartuig aanzag en de kapitein, hoewel uit Ierland geboortig, er verscheidene malen van Macao en Manilla ten handel was aangeweest. $\mathrm{Na}$ zijn vertrek echter waren Gouverneur-Generaal en Raden door berichten uit het Vaderland en uit Engeland verwittigd dat men te doen had met een Ostendischen lorredraaier, die onder een valschen pas voer.

1 Brieven XVII aan GG. en RR. 28 Sept. 1719, 30 Juli 1721, 17 Juli 1722, 7 Oetober 1722 .

2 Huisman, a. w. p. 226.

s Europische Mercurius van 1721, 2e deel, blz. 175. 
Toen dus diezelfde kapitein in November daaraanvolgende opnieuw voor Batavia verscheen, onder voorgeven dat hij zijn reis naar Macao niet had kunnen vervolgen en derwaarts was teruggekeerd om provisie en wat dies meer zij in te nemen, en er zoolang over te blijven tot hij in het volgende voorjaar de reis naar Macao kon hervatten, lieten Gouverneur-Generaal en Raden hem kortweg aanzeggen, dat er voor hem geen het minste gerief zelfs van water en brandhout ten beste was en dat hij op staanden voet de reede had te verlaten ${ }^{1}$ Een ander Ostendisch schip, voor Soeratte bestemd, dat op het laatst van October 1718 de Kaap aandeed moest eenige dagen na dien weder zee kiezen, nadat de gouverneur verboden had het verversching te verstrekken. ${ }^{2}$ In Juli 1719 daagde er te Batavia alweder een op, ditmaal met bestemming naar China. De schipper, die eerlijk bekende dat de bodem uit Ostende in zee was gestoken, verklaarde te Batavia aangeloopen te wezen om verversching en vroeg nu verlof om eenige provisie in te slaan voor zijn zieken. Maar de Hooge Regeering was onverbiddelijk. Zich houdende aan een geheime order, haar bij brief van 6 Januari 1717 door de Bewindhebbers toegezonden, ${ }^{3}$ gaf zij den schipper bevel ten eerste de reede te verlaten, daar hem noch provisie noch verversching zou verschaft worden, "zelfs geen water of brandhout; en deelde hem tegelijk mede, dat ook niemand van het scheepsvolk aan den wal zou worden gedoogd. ${ }^{4}$ Erger verging het een ander schip dat, na door een Vlissingsch koopman voorzien te zijn van een lading tot den handel op de kust van Afrika, in den herfst van 1718 op een patent van den keizer de haven van Ostende verliet. In December daaraanvolgende den mond van de Rio Sestro binnenvallend, werd het aldaar aangehouden

1 Res. GG. en RR. 24 Sept. 1717 en 17 Nov. 1717, en secreete resolutie van 28 Sept. 1717.

2 Huisman, a. w. p. 126. Blijkens een brief van Gouverneur en Raden van de Kaap aan de XVII van 30 Maart 1719 was het aldaar op 29 Oct. 1718 gearriveerd en op 5 Nov. d.a.v. weder de Tafelbaai uitgezeild „zonder eenige verversching ter ordre van den heer gouverneur de Chavonnes te hebben bekomen."

3 Strikt genomen van een Comité uit de XVII, de zoogenaamde "Commissarissen over het werk van de vaart van Ostende op Oost-Indië," ingesteld bij secreete resolutie van de XVII van 12 Sept. 1716 en bestaands in vijf bewindhebbers met de beide advocaten der Compagnie. De tekst van de order van 6 Januari 1717 is mij niet voorgekomen.

4 Res. GG. en RR. 21 Juli 1719. 
door den kapitein van een schip van de Nederlandsche WestIndische Compagnie die het, wijl hem de scheepspapieren niet in orde leken, naar St. George del Mina opbracht. Hier werd de Ostendisehe bodem als een Zeeuwsche "lorredraaier» d. i. smokkelaarsschip beschouwd, dat binnen de limieten van het octrooi der Compagnie verboden handel kwam drijven, en op dien grond deed dan ook de Hollandsche gouverneur de lading ontschepen, liet de bemanning zonder gage op eenige slavenhalers dienen en zond het schip op naar Nederland. De Bewindhebbers van de West-Indische Compagnie stelden den gouverneur niet slechts in het gelijk maar hielden zelfs staande, dat de Ostendenaar zich had schuldig gemaakt aan overtreding van het hem verleende patent. Immers, zoo redeneerden zij, de keizer had daarbij uitdrukkelijk verboden handel te drijven op eenigerlei plaats waar dit aan zijn onderdanen uit krachte van de tractaten met andere mogendheden niet vrijstond, en daaronder viel naar hun oordeel ook ontwijfelbaar het vredesverdrag van Munster, bij hetwelk de koning van Spanje, in wiens rechten en verplichtingen thans voor zooveel de Oostenrijksche Nederlanden aanging de keizer was getreden, met de Republiek was overeengekomen, dat men zich van weerskanten onthouden zou van alle vaart en handel op alle Oost- en West-Indische havens en plaatsen destijds door de wederpartij bezeten. ${ }^{1}$ Hadden de Heeren Zeventien van de Oost-Indische Compagnie naar welgevallen met het recht mogen begaan, van haar dienaren in Indië ware den Ostendenaren gewis geen vriendelijker bejegening wedervaren dan van de dienaren harer West-Indische zuster ter kuste van Guinea. Wij hoorden al dat Gouverneur-Generaal en Raden het weigeren van verversching aan een Ostendisch schip in 1719 grondden op een order in dien geest van de Bewindhebbers in Patria. ${ }^{2}$ Naderhand, op 8 October 1723 en 9 Maart 1724, hebben dezen blijkbaar nog nadere orders op dit stuk naar Batavia laten afgaan. ${ }^{3}$ Haar tekst zelf vindt men nergens opgeteekend. Doch dat de inhoud aan Gouverneur-Generaal en

1 Vgl. de remonstrantie van den markies de Prié aan de Staten-Generaal van 17 Juli 1719, bij Blankenheym, De Compagnie van Ostende, Leiden 1861, blz. 12 vgl.; en het contra-bericht van de Kamer Amsterdam der W. I. C. aan dezelfden van 29 Aug. 1719.

2 Eene geheime nl. van 6 Januari 1717, zie hiervóór blz. 53.

Er is sprake van in de resol. GG. en RR. 13 Febr. 1725. 
Raden vrijheid zal hebben gelaten of wel bevel gegeven om zoo noodig zelfs geen geweld te sparen, mag men afleiden uit hetgeen op 13 Februari 1725 in hun vergadering werd verhandeld. De Gouverneur-Generaal bracht daar namelijk ter sprake den brief van Commissarissen uit de. Zeventien aan de Hooge Regeering van 9 Maart $1724,{ }^{1}$ "tot renovatie der orders op 8 October 1723» door de Zeventien herwaarts gezonden sover het behandelen der schepen uit de Brabantsche trafique en de residentiën der Ostendenaren alhier in Indië, " en legde nu aan de leden de vraag voor "of en hoedanig men althans ${ }^{2}$ de intentie van bovengemelde laatste missive zou kunnen volbrengen, hetzij door kruistochten en het bezetten der bekende vaarwaters en passagiën dan wel anderszins.» De uitslag van de gedachtenwisseling was een eenparig besluit om "voor ditmaal af te zien van dergelijke kostbare bewegingen en armatures ter zee naardien gemeend werd van weinig vrucht te zullen wezen, ter zake men door de komst der Portugeezen en van eenige Chineezen uit Macao en China bereids vernomen heeft het depart van alle vreemde Europeeën uit Canton per retour naar hunne woonsteden, en waaronder ook geweest zijnde twee schepen uit Ostende (na het geadviseerde van hier op 30 Januari dezes jaars aan bovengemelde heeren Commissarissen), zoo blijkt ook de onmogelijkheid om dezelve nog te zullen kunnen beloopen, en daarom is dan ook verstaan in Mei of Juni aanstaande deze zake te nemen in nader overleg als zijnde de tijd, waarin de voornoemde Vlamingen en Brabanders ordinair gewoon zijn in den mond van de Straat Soenda te verschijnen ter vervordering van hunne voyage naar China. ${ }^{3}$ Tot zulke maatregelen van aanval in volle zee is het nochtans in den eersten tijd niet gekomen, want in Augustus 1726 werd van wege de StatenGeneraal aan de Zeventien bericht dat de Republiek, die inmiddels was toegetreden tot het tractaat van Hannover van 3 September $1725,{ }^{4}$ op het punt stond met Engeland en Frankrijk bij een afzonderlijk artikel overeen te komen, dat mèn tegen de Compagnie van Ostende in Indië of elders geen middelen van nadruk en feitelijkheid bij de hand zou nemen

1 De brief was te Batavia ontvangen 3 Febr. 1725.

2 D. i. nu ter tijd.

3 Res. GG. en RR. 13 Febr. 1725.

4 Tusschen Engeland, Frankrijk en Pruisen. 
dan met gemeen overleg. Met het oog daarop, zoo werd den Zeventien aangeschreven, hadden zij er zich van te onthouden in dit opzicht iets te doen zonder voorkennis en goedvinden van de Staten-Generaal. ${ }^{1}$ Groote ergernis, zooals van zelf spreekt, op het Oost-Indische Huis, waar men in de aanschrijving een verkorting zag van de vrijheid, bij verscheidene octrooien aan de Compagnie verleend en door welke het haar mogelijk was geweest zoo groot en machtig, ja zelfs formidabel te worden voor iedereen. ${ }^{2}$

Waar feitelijkheden tegen de Ostendenaren plaats hadden daar werden zij van onze zijde, getuige het voorgevallene op de kust van Guinea in $1718,{ }^{3}$ verdedigd met de bewering, dat het gedoente van de Belgen lijnrecht inliep tegen de bepalingen van den Munsterschen vrede. Die bewering maakte ook jaar in jaar uit als het ware schering en inslag uit van de tallooze vertoogen, welke de Oost-Indische Compagnie met haar pleitbezorgers hier te lande aan overheid en gemeente voorlegde of waarmede de hoven van Weenen en Brussel door de Hollandsche gezanten werden vervolgd. ${ }^{4}$

Evenwel, noch de papieren wapenen van onze Brusselsche en Weenensche diplomaten noch de door ons begane feitelijkheden noch de groot-kapitalistische strijdmiddelen, welke de Compagnie aangreep, waren voorshands bij machte de Ostendenaren uit het vaarwater weg te jagen; integendeel, zij bleven de vaart voortzetten zoo wakker als ooit en behaalden er rijke winsten mede. ${ }^{5}$ Dank zij den korteren duur van hun reizen en de veel geringere bedrijfskosten, konden zij de waren uit het Oosten aanmerkelijk goedkooper afgeven dan wij. ${ }^{6}$ Ook brachten zij betere soorten van goederen aan, en wisten de lading van

1 Brief Staten-Generaal aan de Zeventien en Secreete resolutie van de Staten-Generaal beide van 8 Aug. 1726.

2 Remonstrantíe van de Zeventien aan de Staten-Generaal van 13 Sep. 1726.

3 Zie hiervóór blz. 53.

- Remonstrantiën van de Compagnie aan de Staten-Generaal van 29 Januari 1720 , 24 Juli 1721, 31 Juli 1722, 15 Maart en 9 Aug. 1723; gedrukte vertoogen van Abraham Westerveen en Jean Barbeyrac 1723-1725; vertoogen van Pesters en Hamel Bruyninex te Brussel en te Weenen van 1723 (Wagenaar Vaderl. Historie, XVIII blz. 272).

5 Vgl. Huisman, a. w. p. 143, 184, 212, 241.

6 Valentijn, I. blz. 165. 
hun schepen vrij wat beter te schikken en te proportioneeren dan de Nederlanders. ${ }^{1}$ Daarbij hadden zij nog dit in hun voordeel dat met name het belangrijke artikel van de thee op de kielen van de Compagnie veel onfrisscher overkwam dan op de hunne. Zij plachten die namelijk, even als de Engelschen te Canton, af te pakken in houten kisten van binnen met lood bekleed, terwijl de onzen ze te Batavia afscheepten in kanassers met bamboeblaren toegedekt ${ }^{2}$ - blijkbaar in denzelfden toestand waarin zij uit de jonken werd overgenomen - en daar viel niets tegen te doen, want de Chineezen maakten zwarigheid om de thee op Batavia eveneens in kisten aan te brengen omdat, voor zooveel zij ze niet aan de Compagnie konden debiteeren en bijgevolg aan particulieren moesten slijten, zulke fustage als geheel nutteloos zijnde "verloren ging." "

Wel verre dus dat de gehate "avonturiers, ${ }^{4}$ gelijk de Zeventien hadden verwacht, ${ }^{5}$ spoedig hun Oost-Indische vaart opgaven, wisten zij het zoo beleidvol tegen alle wind en stroom op te zetten, dat een van de kundigste staatslieden van de Republiek, de latere raadpensionaris Simon van Slingelandt in Juni 1724 verklaren moest: "alle middelen, welke de Oost-Indische Compagnie gebruikt heeft om de vaart van Ostende naar Indië tegen te gaan, hebben niet alleen veroorzaakt een ongelooflijke winstderving en verlies aan de Oost-Indische Compagnie, maar bovendien zoo weinig beantwoord aan het oogmerk, dat die van Ostende desniettegenstaande hebben gecontinueerd met groot voordeel naar Indië te varen. ${ }^{6}$

Op den duur nochtans vermochten de Ostendenaren het lot, dat hun boven het hoofd hing, niet af te wenden. Met den steun voornamelijk van de Engelschen, wier Oost-Indische Compagnie van hun concurrentie almede groote schade leed en

1 Brief XVII aan GG. en RR. 28 Aug. 1727.

${ }^{2}$ Brieven XVII aan GG. en RR. 29 Febr. 1724, 15 Maart 1728 en Generale missive GG. en RR. aan de XVII 30 Nov. 1724.

${ }^{3}$ Res. GG. en RR. 9 Maart 1733.

4 Uitdrukking in den brief XVII aan GG. en RR. 28 Sept. 1719.

5 Zie hiervóór blz. 52.

${ }^{6}$ Memorie rakende de tegenwoordige situatie der Nederlandsche O.I. C. met opzicht tot de Indische Compagnie van Ostende, opgesteld in het begin van Junius 1724 (eigenhandig door Slingelandt geschreven en opgenomen in een door hem bijeengebracht recueil van stukken betreffende de Compagnie van Ostende, - Algem. Rijksarchief, Kol. Aanw. n 38). 
en het daarom op haar vernietiging even sterk toelegde als haar Nederlandsche zuster, ${ }^{1}$ slaagde onze diplomatie er eindelijk in op 31 Mei 1727 den keizer een schikking af te dwingen, bij welke hij zich verbond om het octrooi van de Compagnie van Ostende voor zeven jaar lang op te schorten.

Hoe welkom de val der gehate mededingster voor de onzen ook wezen mocht, de uitkomst zou maar al te spoedig leeren dat men er geen volkomen zegepraal mede bevochten had. "Dat gedrocht, aldus luidt het in een brief door een hooggeplaatst dienaar van de Nederlandsche Compagnie in November 1731 aan Sir Matthew Decker, den bekenden president der Engelsche Oost-Indische Compagnie, gericht, "dat gedrocht is wel gekwetst maar niet gedood, ja men ziet dat het ter contrarie als de draak van Hercules, een hoofd afgeslagen zijnde, zeven andere weer opsteekt. ${ }^{2}$ Reeds in Februari 1728 wisten onze zaakgelastigden te Kopenhagen en te Hamburg te berichten, hoe de Denen zich gereed makten om in het erfdeel te treden van die van Ostende. ${ }^{3}$ Een naar Denemarken overgewaaid gerucht namelijk, als zouden de laatstelijk in Holland aangekomen

1 Huisman, a. w. p. 124, 229, 230. Omtrent de zending van Sir Matthew Decker naar Holland in 1718, waarvan Huisman op p. 124 spreekt, vindt men het volgende bericht in een brief van zekeren $\mathrm{L}$. Renard te Amsterdam van 21 Januari 1729 (aan den griffier der Staten-Generaal of den raadpensionaris van Holland?): „e'est par mes avis que le chevalier Decker fut envoyé de Londres iei il y a près de dix ans pour engager les Directeurs hollandois à contribuer avec l'Angleterre une certaine somme pour détourner le marquis de Prié de donner des passeports ni de prêter l'oreille aux nouveautés d'une navigation aux Indes. Cela n'ayant pas eu d'effet ete." De schrijver was, gelijk verder uit zijn brief blijkt, als geheim correspondent in dienst bij de Nederl. O. I. Compagnie om alle mogelijke informatiën in te winnen over het gedoente van de Ostendenaars. De markies de Prié, in 1716 door den Keizer benoemd om in plaats van den afwezigen gouverneurgeneraal Prins Eugenius van Savoye de Oostenrijksche Nederlanden te besturen, gaf als vertegenwoordiger van het landsheerlijk gezag de passen uit voor de Indische vaart van de Belgische reeders. Men gaf hem na, dat hij zeer inhalig was en zijn inkomsten door de meest indelicate middelen placht te vermeerderen, vgl. de Biographie Nationale de Belgique, i. v.

2 Brief van 20 Nov. 1731 (hoogstwaarschijnlijk van den eersten advocaat der Nederl. O. I. Compagnie Abraham Westerveen aan Sir Matthew Decker). Decker, een Amsterdammer van geboorte zooals men weet, was destijds een van de handelsvorsten van Londen.

${ }^{3}$ Brieven van Van Assendelft en Mauricius, resp. gezanten te Kopenhagen en te Hamburg, aan den griffier der Staten-Generaal of den raadpensionaris van Holland, 10 en 17 Febr. 1728. 
retourschepen uit Indië de tijding hebben medegebracht dat de keizer van China den handel met onze Oost-Indische Compagnie had verboden, bracht te Kopenhagen de vraag op het tapijt of men van deze gelegenheid geen partij behoorde te trekken om nu van uit Denemarken eenige schepen uit te rusten voor den handel op China, en zoodoende de Deensche Oost-Indische Compagnie uit haar diep verval op te beuren. ${ }^{1}$ Aangezien in Denemarken zelf geen geld hiertoe voorhanden was begreep men een beroep te moeten doen op buitenlandsch kapitaal. Toen dus het besluit was genomen om te Altona, een bezitting van den Deenschen koning, een kantoor of filiaal op te richten van de oude Compagnie, stelden de ontwerpers van het plan zich in betrekking met een Amsterdamsch koopman, zekeren Josias van Asperen, van wien men op grond van de aanzienlijke vorderingen die hij op de Deensche kroon had, verwachten mocht dat hij zooveel te gemakkelijker voor de onderneming zou te winnen zijn. ${ }^{2}$ Zoo geschiedde ook. Van Asperen ging op de hem gedane voorslagen in, en verhuisde in het begin van 1728 naar Altona, ${ }^{3}$ waar hij door de Denen op het hartelijkst werd verwelkomd - men noemde hem (zoo schreef Mauricius uit Hamburg) "een engel, die uit den hemel scheen gevallen te zijn om de vervallen Compagnie te herstellen " begon te werken. Groot succes viel hem daarbij niet te beurt, naar het schijnt, want schoon de directeuren van de Deensche Compagnie dagelijks zitting hielden tot het aannemen van inschrijvingen op de aetiën, was er op 15 Mei 1728, gelijk de Nederlandsche gezant van Assendelft uit Kopenhagen naar Den Haag overbriefde, nog maar voor 30.000 rijksdaalders 5 ingeschreven en dat uitsluitend door de directeuren zelf. ${ }^{6}$ Het uiterste

1 Huisman, a. w. p. 457.

${ }^{2}$ Assendelft aan den raadpensionaris Slingelandt 6 Maart 1728. Ook volgens Mauricius was napparentelijk de betaling zijner (van Asperen's) pretensiën op de kroon van Denemarken daartoe-geen klein lokaas geweest" (brief aan griffier of raadpensionaris 19 Maart 1728).

3 Mauricius a9n den griffier der Staten-Generaal of den raadpensionaris 18 Mei 1728.

4 Mauricius aan als voren 19 Maart 1728.

${ }^{5}$ Bij de voorwaarden van Inschrijving, op 6 April 1728 door de Directeuren uitgegeven, was de grootte van elke nieuwe actie op 1000 rijksdaalders bepaald.

6. Van Assendelft aan als voren 15 Mei 1728. 
dat Van Asperen persoonlijk inbrengen kon, meldde eenige dagen later onze zaakgelastigde te Hamburg, Mauricius, bestond in 140 actiën, door hem zelf medegebracht, benevens 100 nieuwe die onlangs, naar men wilde, uit Holland waren overgekomen: laat daar, schrijft hij, nu nog een gelijk getal Engelsche en Deensche bijkomen, dan blijft het toch altoos nog verre beneden de 2250 , welke benoodigd zijn. ' Een halve maand na dien schrijft hij: "de Compagnie van Altona ligt in slaap, en zoolang er geen vreemd geld komt om ze wakker te klinken, zijn alle ferme resoluties waarvan men nog breed blijft opgeven papieren pleisters.» ${ }^{2}$

De groote vraag bleef met dat al bestaan of niet misschien te eeniger tijd de Ostendenaars hun fonds in de nieuwe Deensche onderneming zouden overbrengen. Beiden, Assendelft en Mauricius, gaven op dit punt herhaaldelijk hun ernstige bezorgdheid te kennen. De eerste verklaarde op het laatst van Maart 1728 dat hij met de overige vreemde ministers te Kopenhagen bevestigd werd in het denkbeeld, dat de Denen het met de Belgen eens waren en binnenkort de Compagnie van Ostende naar Altona hoopten verplaatst te zien. ${ }^{3}$ In gelijken zin liet zich omstreeks denzelfden tijd Mauricius uit: "dat die van Ostende daaronder spelen stel ik hoe langer hoe vaster (zegt hij), en alle de eeden van Van Asperen ter contrarie verwrikken bij mij dat geloof niet.» 4 Trouwens, het is bekend dat gedurende het eerste halfjaar van 1728 van uit Denemarken metterdaad voorstellen in dien geest zijn gedaan zoowel aan het Hof van Weenen als aan het geheime comité te Antwerpen, waaraan na hare schorsing de behartiging van de zaken der Ostendische Compagnie was toevertrouwd. ${ }^{5}$

Het uitzicht op een vereeniging der beide vreemde compagnieën, gelijk Assendelft en Mauricius ze afschetsten, was wel geschikt om de belanghebbenden hier te lande schrik aan te jagen, want vestigde zich aan de Elve een goed georganiseerde maatschappij

\footnotetext{
1 Mauricius aan als voren 18 Mei 1728.

2 Mauricius aan als voren 4 Juni 1728.

${ }^{3}$ Assendelft aan als voren 23 Maart 1728, zie ook zijn vroegeren brief van 2 Maart 1728.

4 Mauricius aan als voren 19 Maart 1728 , zie ook zijn vroegere brieven van 10 en 24 Febr. 1728.

${ }^{5}$ Huisman, a. w. p. $458,459$.
} 
voor den handel op Oost-Indië en China, dan liep onze OostIndische Compagnie gevaar in de Noordsche rijken, waar een groote omzet plaats vond van Oostersche waren, ${ }^{1}$ van haar plaats te worden weggedrongen. Of zooals eenige jaren later Sir Matthew Decker het uitdrukte: "een Compagnie aldaar geestabilizeerd apprehendeerde ik veel gevaarlijker als de Compagnie te Ostende of ergens anders, want die wel gereguleerd zijnde zouden wij beiden ${ }^{2}$ zooveel van ons debiet verliezen, dat wij voor een gedeelte onze winkel wel mochten opsluiten.» 3 Tenauwernood was dan ook in den Haag de brief ontvangen van 10 Februari 1728 , waarin Mauricius het ontwerp van de Altonasche Compagnie had gemeld en de meening uitgesproken, dat er mogelijk plannen bestonden "om van de débris der Compagnie van Ostende een nieuw gebouw te maken, ${ }^{4}$ of de Staten van Holland besloten het gewichtige nieuws aanstonds mede te deelen aan de binnen hun provincie gevestigde Kamers van de Oost-Indische Compagnie met order om hun advies en consideratiën in te zenden op het Deensche plan, dat op het touw werd gezet, zoo zeggen zij met eenige verwondering, "ter zelver tijd dat de vaart van de Ostendische Compagnie naar de Indiën en daarondèr mede naar het zelve rijk (China) gesuspendeerd werd», en om daar tevens "particulierlijk bij te voegen de redenen en oorzaken, waarbij het toekwam dat de Compagnie van Ostende had kunnen eenige jaren herwaarts Europa vervullen met Chineesche waren, ondertusschen dat de Nederlandsche Compagnie zeer weinig van die waren overgebracht had, en daarop doen zoo considerabele winsten dat die jegenwoordig dienden tot een motief en encouragement om op de Elve aan te leggen een vaart naar China, misschien niet minder nadeelig voor de Nederlandsche Oost-Indische Compagnie als die van Ostende, terwijl de Staat met zooveel moeite en kosten bezig was om uit te werken de vernietiging van de Ostendische Compagnie. $)^{5}$

Of het verwijt hier aan de Bewindhebbers voor de voeten

1 Huisman, a. w. p. $426,427$.

2 Nl. de Engelsche en de Hollandsche O. I. Compagnie.

${ }^{3}$ Brief van Sir Matthew Decker (aan den eersten Advocaat der O. I. Compagnie Abraham Westerveen?) 14 Dec. 1731 (Kol. Arch. $n^{\circ} 11304$ ).

4 De brief werd ontvangen op 16 Februari 1728 en daags daaraan reeds door den raadpensionaris in de dagvaart van Holland overgelegd.

1 Res. Staten van Holland 17 Febr. 1728. 
geworpen, als zouden zij bij hun kamp tegen de Ostendenaren zijn te kort geschoten in wakkerheid, wel geheel billijk was? Wij hebben gezien hoe zij van 1719 tot 1722 de Hooge Regeering te Batavia in brief op brief hadden aangeschreven toch een zoo ruim mogelijken voorraad van Chineesche koopwaren af te zenden ten einde de Europeesche markt voor hun Belgische mededingers te bederven, al moest er desnoods de Compagnie zelve schade door belopopen; ${ }^{1}$ hoe zij de Belgen met den sterken arm uit de Indische zeeën hadden zoeken te weren, ${ }^{2}$ en met dit bedrijf waarlijk niet uit vrijen wil waren opgehouden maar alleen op een uitdrukkelijk verbod van de Staten-Generaal in Augustus $1726 ;^{3}$ en wij weten dat zij sedert herhaaldelijk bij de Staten-Generaal ernstig hebben aangehouden om intrekking van dat verbod, opdat de Compagnie weder volgens haar oude vrijheid geweld zou kunnen gebruiken, waar zij dit binnen het gebied van haar octrooi noodig oordeelde, en dus de Ostendische schepen beoosten de Kaap door haar konden genomen en opgebracht worden. ${ }^{4}$ Dat er door de Compagnie vergelijkenderwijs zoo weinig Chineesche goederen naar Europa waren overgevoerd, zooals den Bewindhebbers door de Staten van Holland voorgehouden werd, lag niet aan hen doch uitsluitend aan GouverneurGeneraal en Raden die, hoe vaak er ook door de Zeventien op was aangedrongen, ${ }^{5}$ maar steeds geen schepen naar China hadden willen zenden om daar zelf de benoodigde waren te gaan af halen. Vrees voor soortgelijke knevelarijen en moeilijkheden als onze kooplieden daar te lande in vroeger tijd van de overheden hadden moeten ondergaan; ${ }^{6}$ hoop dat de Chineesche vaart der Ostendenaren spoedig wel van zelf te niet zou loopen; ${ }^{7}$ bezorgdheid dat de vaart van de Chineesche jonken op Batavia er door zou verminderen tot groote schade van Compagnie's in- en uitgaande rechten en van de stadsbelastingen aldaar, ${ }^{8}$ zoo het een als het ander had de Hooge Regeering van het

1 Zie hiervóór blz. 52.

2 Zie hiervóór blz. 52-54.

3 Zie hiervóór blz. 55 .

4 Resol. XVII 19 Febr., 31 Maart, 4 April 1727.

${ }^{5}$ Brieven XVII aan GG. en RR. 28 Sept. 1719, 30 Juli 1721, 17 Juli 1722, 7 Oct. 1722.

6 Zie hiervóór blz. 43, 45.

7 Generale missives GG. en RR. aan de XVII 30 Nov. 1721 en 30 Nov. 1722.

s Zie hiervóór blz. 35, 43. 
aanknoopen eener rechtstreeksche handelsverbinding met China gestadig afkeerig gemaakt. En er was nog meer dat haar terughield: "men heeft (zoo spreekt zij ergens) daartoe niet aan handen de gerequireerde bedienden van ervarenheid en nog minder het benoodigde zilver, dewijl door verkoop van koopmanschappen de negotie alleen in China niet zou te doen wezen, en tot den inzaam der ordinaire jaarlijksche retouren op de Westercomptoiren ' zelfs geen penningen genoeg kunnen worden gefourneerd. $2^{2}$

Zooveel was duidelijk, zou het plan van de directe vaart op China werkelijkheid worden, dan hadden de Zeventien zelf de leiding in handen te nemen. Uitlokkend weliswaar was de toestand in China, gelijk de Indische berichten van 1727 dien afmaalden, atlerminst. Een Portugeesch schipper van Macao, in Februari van dat jaar te Batavia aangeland, had in een onderhoud met den Compagniessabandhaar of havenmeester aldaar een donker tafereel ontrold van de "vexatiën en zware lasten," waar de vreemde kooplieden te Canton onder gebukt gingen. Naar zijn zeggen onderdrukte de onderkoning van Canton hen "zwaarlijk als moetende voor den in- en uitvoer benevens eenige andere onkosten te zamen betalen 21 procento, te weten 10 voor den in-, 10 voor den uitvoer en 1 procento voor eenige andere onkosten, en bovendien moesten dezelve voor ankerage en meting der schepen afzonderlijk kosten doen met voor een schip van 400 à 500 ton te betalen 3000 tailen.» Ook had hij verteld dat de onderkoning "zich zou hebben uitgelaten van meening te zijn om in het vervolg de vreemdelingen, die daar aankwamen, even zoodanig te bandelen als de Japanners aan andere natiën in haar land gewoon waren te doen.» Verder durfden volgens hem de Chineesche schippers geen zee te kiezen uit angst voor de Engelschen en Franschen, die daar laatst waren aan geweest en gedreigd zouden hebben, dat zij zich voor de afpersingen van den onderkoning op de Chineesche

1 D. i. de Compagniescomptoiren bewesten Malakka.

2 Resol. GG. en RR. 19 Mei 1724. Het laatstgenoemde bezwaar was door hen al reeds aangeroerd in hun brief aan de XVII van 3 Dec. 1723. Tot de vaart op China, zeggen zij daar, noude ook van noode wezen veel zilvergeld, hetwelk men in dezen tijd zoo hoog noodig heeft op onze vaste en gestabiljeerde comptoiren langs de kusten van Indië.... boven het afleggen der alsnog resteerende interestgelden, waarmede men nog grootelijks voornamelijk in Bengalen en te dezen kasteele (Batavia) bezwaard is". 
schepen zouden wreken. ${ }^{1}$ Ofschoon dit bericht reeds op het laatst van September 1727 te hunner kennis kwam ${ }^{2}$ heeft het nochtans de Zeventien niet van hun opgevatte plannen afgeschrikt. Want toen op hun vergadering van 29 October 1727 in behandeling kwam de bij den oproepingsbrief uitgeschreven vraag "of het in deze tijdsgelegenheid van dienste zoude zijn om één à twee schepen directelijk hier vandaan naar China te zenden, viel aan den hierin opgesloten voorslag een zoo goede ontvangst ten deel dat tot de expeditie besloten werd. De uitvoering van het werk werd geheel overgelaten aan de zorg van de Kamer Amsterdam, ${ }^{3}$ met volstrekte machtiging rom zoodanig schip of wel twee schepen, bemand met zoodanige personen hetzij ter volbrenging van de negotie als zeevarenden, daartoe te mogen aanleggen en aannemen, en dezelve schepen te voorzien met zoodanige zaken als dezelve zal vermeenen te behooren, daarbeneffens aan de schippers en andere bediendens daar na toe zullende gaan zoodanige instructiën wegens hare te nemene reize te geven als verders ter zake van den handel en negotie strekkende zal oordeelen met den dienst van de Compagnie te convenieeren.» ${ }^{4}$

Zoo de Zeventien met hun beslissing van 29 October 1727 een geheel nieuwe vaart op China instelden, een vaart namelijk niet van Batavia doch van onze eigen havens uit, men moet hier echter niet uit afleiden dat zij door deze expeditiën den gebruikelijken handel van de Chineesche jonken op Batavia wenschten te zien vervangen of ook maar verminderd. Wat hen tot het besluit aandreef, de eerste advocaat of secretaris van de Compagnie heeft het ergens met zooveel woorden gezegd, was de zucht "eensdeels om (in China) een oog in het zeil te

1 Bericht van den sabandhaar te Batavia aan den Gouverneur-Generaal 21 Maart 1727.

${ }^{2}$ Het was uit Batavia afgezonden met het schip Pallas, dat op 1 April 1727 van daar vertrok en op 29 Sept. 1727 in Tessel binnenviel.

3 De Kamer Amsterdam had daartoe zelf haar veelvermogenden invloed laten werken, want bij resolutie van 28 Oct. 1727 had zij haar afgevaardigden ter Vergadering van Zeventien verzocht "het daarheen te dirigeeren, dat deze expeditie wierd ondernomen direct van hier naar China en de behandeling daarvan in het geheel aan deze Kamer gelaten wierd of, bijaldien zulks eenige obstakelen zoude mogen vinden, dat dan de Kamer van Zeeland een van de twee sehepen zoude equipeeren doch in alles met communicatie van deze Kamer".

4 Resol. XVII 29 Oet. 1727. 
houden en van nabij te zien wat daar omging, anderdeels om door een opulenten aanbreng van die koopmanschappen, dewelke de Ostendenaars tot de vaart op de Oost-Indiën meest hadden geanimeerd, ${ }^{1}$ haar te doen zien dat de winsten bij continuatie zoo groot niet meer zouden vallen als zij haar wel verbeeldden,$x^{2}$ - in het kort de toeleg om door overgroote aanvoeren van Chineesche waren op de Europeesche markt nog sterker in de verkoopprijzen tegen hun concurrenten, Ostendenaars, Denen en anderen, te kunnen kladden dan tot dusver mogelijk was geweest. Dat de schade en de verliezen, welke met die tactiek onvermijdelijk gepaard gingen, het spreekwoord zouden bewaarheiden van zijn buurmans glazen in te gooien met ducatons, lag voor de hand. Maar in de oogen van de Zeventien, wij weten het uit hun vroegere uitlatingen, ${ }^{3}$ werden de offers door de groote belangen, die op het spel stonden, gewettigd, en ook, de Compagnie was "door Gods goedheid genoegzaam in staat om een kwaden stoot te kunnen uitstaan, » meenden zij. ${ }^{4}$ Niets kon hun dus welgevalliger zijn dan dat de jonken de vaart op Batavia bleven voortzetten, opdat van daar insgelijks een zoo ruim mogelijke voorraad van Chineesche koopmanschappen herwaarts kon worden afgezonden. Ten einde hier te vaster op te kunnen rekenen, met name wat de thee betrof, het artikel welks winsten de anđere Europeanen juist het sterkst tot den handel op China aanmoedigden en hen alom in de Indische negotie deden indringen, gaven zij de Hooge Regeering in Maart 1728 order om onverwijld, zonder tijdverlies, "zooveel thee voor rekening van de Compagnie van China te laten komen tot een ongelimiteerde quantiteit» als zij vermeende " dat tot een redelijken prijs en inzonderheid in betaling voor specerijen zou te bemachtigen zijn» - en dat wel in goede soorten, gelijk de Ostendenaars ze tot dusver hadden aangebracht, en tot beter bewaring van haar frischheid afgepakt evenals bij dezen in met lood bekleede kisten in plaats van in de kanassers, welke de Chineezen voor het vervoer naar Batavia plachten te gebruiken.

1 Het waren vooral de winsten op haar Chinaschen handel geweest, die de Compagnie van Ostende tot haar ruime dividenden hadden in staat gesteld, zie Huisman, a. w. p. 372.

2 Brief van den eersten advocaat der Compagnie Abraham Westerveen aan Sir Matthew Decker 30 Nov. 1731.

3 Zie hiervóór blz. 52.

* Brief van Westerveen aan Decker 30 Nov. 1731. DI. 73 
Te gelijker tijd deden de Zeventien de Indische regeering een middel aan de hand om den theehandel voor de Europeesche concurrenten in nog "grooter confusie te brengen»: niets meer of minder namelijk dan het in zwang brengen van de theecultuur in de landerijen op Java, die onder Compagnie's district lagen, aan de Kaap, op Ceilon, overal waar de Compagnie volstrekt heer en meester was. "Men behoorde ten minste een proef te nemen," zoo schreven zij, "van het theezaad in soorten van China te laten komen" en het in die landen "te doen zaaien en op de Chineesche wijze in ovens te drogen.s Tegen dit denkbeeld, zeggen zij, "zullen mogelijk al wederom wel verscheidene objectiën kunnen gemaakt worden, als namelijk dat de klimaten al te veel differeeren, dat mogelijk het zaad niet zoude opkomen of ten minste dat de bladeren van die geur en smaak niet zouden kunnen zijn als die van China, dat men overal de rechte manier van drogen niet zouden kunnen hebben en diergelijke meerder, maar wij verbeelden ons dat de moeite en kosten, die hier in alle gevallen aan vast zouden zijn, in het duizendste deel niet te vergelijken is bij de onnoemelijke voordeelen, die de Compagnie bij succes allerwege daarvan zal genieten, en al was het dat deze nieuwe culture in de landen van Indië vooreerst van de vereischte deugd en smaak niet mochte bevonden worden, dat alles door den tijd meer en .meer in perfectie wordt gebracht, ten minste dat die thee, zij was zoo zij was, aan den waren Chineeschen theehandel ${ }^{1}$ veel nadeel en afbreuk zoude toebrengen, dewijl nu de mode in Europa is al te koopen wat maar thee genaamd kan worden, de goede met slechter soorten te vervalschen en zoo alles aan de man geraakt. Voorts om te toonen hoezeer ons deze zaak ter harte gaat, qualificeeren wij UEd. mede (voegen zij er bij) om een premie te beloven aan dengene, die het eerste pond thee onder 's Compagnie's district zal ingewonnen en aan dezelve geleverd hebben, hetzij Chineezen, Javanen, Compagniesdienaren of anderen die maar lust daartoe mochten hebben, zonder onderscheid van personen, zóó nochtans dat de handel van de ware Chineesche thee op Batavia alleszins moet worden geconserveerd en in plaats dat men daaraan zou willen te kort doen, dat UEd. dezelve integendeel meer en meer moeten

1 D. i. den handel in de echte Chineesche thee. 
trachten te vergrooten, alzoo wij oordeelen dat de tegenwoordige tijdsomstandigheden dit alles voor den dienst van de Compagnie ten hoogste komen te vereischen, te meer omdat wij tot versterking van deze opinie een klaar voorbeeld hebben aan de koffie, welkers culture men voor dezen mede zoo onmogelijk heeft geoordeeld en nu van dat succes wordt bevonden, dat door den opulenten aanbreng van Java, schoon die koffie minder van deugd wordt geacht als die van Mokka, echter meest alle de Europeanen van den handel op Mokka zijn afgezoet ${ }^{1}$ en de een voor den ander die koopmanschap jegenwoordig wel kan laten varen. ${ }^{2}$ Ter bestrijding van het "goddeloos dessein, " als zij het noemden, van plichtvergeten landgenooten gelijk van Asperen ${ }^{3}$ en het woelen van de nieuwe concurrenten, die zich opdeden in Duitschland, in Denemarken, in Polen, overal, stond de Compagnie - op dezen zin liepen hun latere brieven naar Indië - geen deugdelijker wapen ten dienste dan een grooter aanvoer van thee "hetzij met inkoopen, met aanplanten of hoedanig het zoude mogen wezen.» ${ }^{4}$ Men kan zich de ergernis der Bewindhebbers voorstellen toen, in. weerwil van al hun aandrang, de Hooge Regeering in 1728 wederom een slechts "geringe, niet naamwaardige quantiteit van het vurig verlangde artikel overstuurde. Mocht hiertegen worden ingebracht dat met de jonken uit China geen grooter voorraad ten hunnent was aangekomen, dan wilden zij "wel eens weten (dus beten zij Gouverneur-Generaal en Raden toe) hoe het dan mogelijk zij dat het particuliere varende volk zooveel quantiteit thee in het Vaderland heeft kunnen overbrengen, en of die thee zoo wel niet voor de Compagnie als voor particulieren te bekomen is. ${ }^{5}$

De Hooge Regeering, het moet gezegd worden, bleef niet werkeloos. IJverig bijvoorbeeld droeg zij er zorg voor dat de jonken uit China, van welke de Compagnie voor haar theehandel grootendeels af hankelijk was, geregeld en ongestoord met hun vaart op Batavia bleven doorgaan. Zij lichtte bijwijlen de hand met de plakaten, ${ }^{6}$ die hun verboden een grooter getal Chineezen mede te brengen dan zij voor het eigenlijke scheepswerk be-

${ }^{1}$ D. i. hun de handel op Mokka minder smakelijk is gemaakt.

2 Brief XVII aan GG. en RR. 15 Maart 1728.

3 Als voren.

4 Brieven XVII aan GG. en RR. 17 Aug. en 12 Oct. 1728, 24 Febr. I730.

"Brief XVII aan GG. en RR. 21 Maart 1729.

6 Zie hiervóór blz. 40. 
hoefden $;{ }^{1}$ zij liet, wanneer een Macaosch schipper dezen of genen Chineeschen koopman wegens particuliere schuldvorderingen op zijn terugreis dreigde lastig te zullen vallen, een waarschuwing uitgaan dat een diergelijk bedrijf zou gewroken worden op alle Portugeesche vaartuigen zonder onderscheid, die te Batavia aanliepen $;^{2}$ zij liet de jonken, om ze voor aanrandingen onderweg te vrijwaren, door Compagnieschepen tot buiten straat Banka begeleiden. ${ }^{3}$ Meer moeite had zij, naar haar eigen zeggen, met de voldoening van de reusachtige bestellingen van thee, die zij uit het Vaderland ontving, want behalve dat men op den aanbreng der Chineezen geen vasten staat kon maken, bleek het grootste gedeelte somtijds van zoo ordinaire en slechte hoedanigheid te wezen, dat er op den ongelimiteerden eisch der Bewindhebbers ten hoogste maar een 300.000 pond kon worden ingekocht. Echter beloofde zij de Heeren Meesters met de Chineesche jonkschippers te zullen spreken over het aanbrengen van groote partijen, al ware het tot een bedrag van zesmaal honderd duizend pond, en dat welafgepakt in kisten naar de methode van de Ostendenaars. Geen mindere zorg zou zij wijden aan de haar geordonneerde aanplanting van het gewas in 's Compagnie's districten zelve: men zou er "alle uitdenkelijke middelen s toe in het werk stellen, "hoewel de apparentie tot deze culture» haars inziens "niet zeer favorabel scheen, alzoo verscheidene liefhebbers bereids hadden ondervonden dat de theeboom in deze gewesten niet wilde groeien.» Wat ons evenwel niet weerhouden zal, zoo liet zij er op volgen, "van een nadere preuve te nemen onder belofte van een premie aan den leverancier van het eerste pond thee, dat alhier zal wezen gewonnen, bijaldien men de plantjes of zaden naar onzen wensch in een goeden staat zal kunnen overkrijgen, op hope dat het mettertijd niet minder zal slagen als de culture der koffieboonen, dewelke in den jare 1697 is begonnen op het land van den heer Generaal Joan van Hoorn loffelijker memorie, die dezelve op vele plaatsen dede voortplanten doch met geen eenparig succes alzoo in den volgenden tijd de Bovenlanden daartoe wel het bekwaamste werden bevonden." 4

\footnotetext{
1 Generale missive GG. en RR. aan de XVII 5 Dec. 1726.

2 Generale missive GG. en RR. aan de XVII 30 Nov. 1727.

s. Zoo geschiedde o. a. in 1728 blijkens generale missive GG. en RR. aan de XVII 8 Dec. 1728.

4 Generale missive GG. en RR. aan de XVII 8 Dec. 1728.
} 
Men ziet, Heeren Zeventien hielden vast aan hun ouden stelregel: geen cultures ondernemen door de Compagnie zelve maar die geheel overlaten aan particuliere planters. ${ }^{1}$ Op zijn hoogst wilden zij voor de teelt van het een of ander product het particulier initiatief slechts aangewakkerd zien, wanneer de Compagnie dit product, zooals nu met de thee het geval was, voor haar handel behoefde. In zulk een aanmoediging hebben Gouverneur-Generaal en Raden destijds, pas drie jaar nadat zij den overeengekomen prijs van de door de Preangerhoofden reeds afgeleverde koffie eigenmachtig hadden verlaagd, ${ }^{2}$ blijkbaar zoo weinig heil gezien dat zij aan eenige uitloving van premies voor theecultuur niet meer hebben gedacht. ${ }^{3}$ Trouwens de Zeventien werden door het woelen van Compagnie's concurrenten al te zeer in het nauw gedreven om nog langer geduld te kunnen oefenen: in October 1728 deelden zij aan hun lasthebbers te Batavia mede hoe zij, "in die omstandigheden niet kunnende blijven of wachten het onzeker succes v van hun orders, tot het besluit waren genoodzaakt om een rechtstreeksche handelsverbinding te vestigen tusschen Nederland en China. ${ }^{*}$

De Kamer Amsterdam, aan wie gelijk wij reeds zeiden de Zeventien in hun najaarsvergadering van 1727 het gansche beleid van de Chinasche expeditie hadden overgedragen, ${ }^{5}$ was op dat tijdstip bereids zoover met het werk gevorderd dat de voor China bestemde bodems Coxhorn en Buren eerstdaags gereed zouden zijn om zee te kiezen. ${ }^{6} \mathrm{Zij}$ waren beide in het voorjaar van 1727 aangebouwd en van het kleinste charter, dat toenmaals bij de Kamer Amsterdam in zwang was: 120 voet lang en van 75 last (=150 ton) inhoud. ${ }^{7}$ In September had de Kamer voor het eigenlijke negotiewerk drie supercarga's en drie boekhouders benoemd. ${ }^{8}$ Een van de supercarga's, Jan de Jongh, had voorheen, schoon Amsterdammer van geboorte, op

1 Vgl. De Haan, Priangan, I blz. 73\%, 117\%, II blz. 350.

2 Bij resol. GG. en RR. 15 Januari 1726, zie de Haan, a. w. I blz. 124 \%.

3 De Haan, a. w. II blz. 864.

4 Brief XVII aan GG. en RR. 12 Oet. 1728.

5 Bij resol. 29 Oct. 1727, zie hiervóór blz. 64 .

- Brief XVII aan GG. en RR. 12 Oct. 1728.

7 Resol. Kamer Amsterdam 23 Sept. 1728 en Notitieboek van Compagnie's uitgeloopen schepen (1688-1803). Blijkens de opgaven in het Notitieboek waren destijds bij die Kamer de vier volgende charters in gebruik: 160 voet en 180 last, 145 voet en 140 last, 130 voet en 100 last, 120 voet en 75 last,

8 Resol. Kamẹ Anusterdam 23 Sept. 1728, 
een Chinaschip van de Compagnie van Ostende gediend ${ }^{1}$ en zich dus aan overtreding van 's lands plakaten schuldig gemaakt, ${ }^{2}$ doch de Bewindhebberen zullen voor die zonde de oogen hebben geloken, denkelijk maar al te verheugd op iemand van zijn ervaring de hand te kunnen leggen. Er kwam bij dat de Bewindhebbers niet te nauw mochten zien want de keus van geschikte personen was naar het schijnt tamelijk beperkt. Twintig jaar later wist de toenmalige Eerste Advocaat der Compagnie, Nicolaas Hartman, er nog van te spreken hoe men in 1728-1733 de carga's voor den Chinaschen handel "tot hooge maandgelden zelfs tot 120 gulden" had moeten koopen als het ware, ${ }^{3}$ en Hartman noemt hier nog niet eens het maximum-salaris. Immers, terwijl de boekhouders en Tweede supercarga's in 1728 ieder voor een wedde resp. van 50 en 120 ter maand werden aangenomen, legden de Bewindhebbers aan elken Eersten supercarga een maandgeld toe van 150 gulden. * Als emolument genoten zij daarenboven het recht om op de uitreis mede te nemen: elke Eerste en Tweede supercarga "twee kisten ieder van 5 voet, en verders zoodanige goederen als op de lijst voor een opperkoopman naar Indië gaande bekend stonden," elke boekhouder "twee kisten van die grootte en die verdere zaken als op de lijst van een onderkoopman naar Indië gaande bekend stonden.» ${ }^{5}$ Op de terugreis uit China, zoo ver

1 Zoo schrijven een paar Chineesche kooplieden uit Canton aan de XVII op 29 Dec. 1729; volgens hen was de Jongh tweemaal met de Ostendenaars „als schrijver" te Canton geweest. Werkelijk komt een Jean de Jonghe voor onder de bemanning van het in 1726 te Ostende voor China uitgeruste schip De Arend, zie Mertens, La Compagnie d'Ostende, in Bulletin de la Société royale de Géographie d'Anvers VI (1881) p. 398.

2 Zie hiervóór blz. 50 .

3 Consideratiën over de vaart naar China door Hartman aangeboden aan Prins Willem V 17 Aug. 1751 (Papieren Hope Kol. Arch. 8471).

4 Resol. Kamer Amsterdam 23 Sept. 1728.

${ }^{5}$ Als voren. Volgens de lijst, vastgesteld bij resol. XVII 30 Oct. 1713, mocht een opperkoopman op de uitreis naar Indië medenemen: 2 kisten met plunje, ieder lang 5 voet, hoog 2 en wijd 2 voet Rijnlandsche maat, doch vrouw en kinderen hebbende 3 kisten, meer dan 4 kinderen hebbende nog een kist daarboven, alsmede de volgende goederen: 5 pijpen of 10 amen wijn of bier, 4 flesschenkelders, 12 hammen, 8 stukken gerookt vleesch, 15 kazen mits alles te zamen niet zwaarder wegende dan 500 pond, 2 vierendeels boter of 1 aam wijn of bier, 1 vaatje zalm, 1 vaatje haring, 2 gerookte zalmen, 1 hoedenkas en 1 vaatje ansjovis; - een onderkoopman: 2 kisten met plunje, doch vrouw en kinderen hebbende 3 kisten, meer dan 4 kinderen hebbende 
ordenden de Bewindhebbers, zouden de Eerste en Tweede supercarga elk vijf en de boekhouders ieder twee kisten mogen medebrengen, met dien verstande evenwel dat "de andere zaken volkens de geallegeerde lijsten aan haar wel werden toegestaan voor de uitreize doch gansch niet en in geenen deele voor de reize herwaarts aan te doen.» 1

Nadat met het aanmonsteren van het scheepsvolk en het inschepen van de lading een paar maanden waren verloopen, was in den aanvang van December de eene bodem, Coxhorn, ver genoeg gevorderd om uit te kunnen zeilen. Daar de wind uit den gunstigen hoek waaide, vonden de Bewindhebbers goed het schip onverwijld zee te laten kiezen zonder te wachten op zijn makker Buren, die op het oogenblik nog niet gereed was; ${ }^{2}$ en dies lichtte het op 5 December 1728 ter reede van Tessel zijn anker. ${ }^{3}$ Buiten de twee supercarga's, den boekhouder en de beide scheepsjongens bestond de bemanning in 85 koppen, waaronder gelijk veelal op de schepen van de Compagnie een vrij aanzienlijk getal vreemdelingen, onder anderen een twintigtal Duitschers, drie Zweden, een enkele Franschman, Noor, Deen, Italiaan, Engelschman, Rus enz. ${ }^{+}$Met uitzondering van die van den schipper en den trompetter, welke iets hooger liepen, ${ }^{3}$

nog een kist daarboven, alle lang 5 voet Rijnlandsche maat, hoog en wijd 2 voet, alsmede de volgende goederen: 4 pijpen of 8 amen wijn of bier, 4 flesschenkelders, 12 hammen, 8 stukken gerookt vleesch, 12 kazen mits alles te zamen niet zwaarder wegende dan 320 pond, 2 vierendeels boter of 1 aam wijn of bier, 1 hoedenkas, 1provisiekelder, 1 mand met pijpen lang 3, wijd 2, hoog 1 voet.

1 Resol. Kamer Amsterdam 23 Sept. 1728. Met de hier geallegeerde lijst is bedoeld die, welke door de XVII werd vastgesteld op 5 Oct. 1717. Zij bepaalde dat een opperkoopman op de thuisreis mocht medebrengen: 3 kisten lang 5, hoog en wijd 2 voet, doch vrouw en kinderen hebbende 4 zulke kisten, en verder 2 matrozenkisten van 4 voet lang en $1 \frac{1}{2}$ voet hoog en breed, waarvan een met lijnwaden en zijdestoffen mocht gevuld worden, benevens 2 flesschenkelders van 12 flesschen elk en 2 potten atjaar (bamboespruitsels en andere groente in zuur) of tamarinde; en een onderkoopman: 2 kisten lang 5, hoog en wijd 2 voet, 3 flesschenkelders van 12 flesschen of een kistje hoog en breed $1 \frac{1}{3}$ voet, lang $3 \frac{1}{2}$ voet met lijnwaden en zijdestoffen in de plaats, alsmede 2 potten atjaar.

3 Resol. Kamer Amsterdam 2 Dec. 1728.

3 Notitieboek van Compagnie's uitgeloopen schepen (1688-1803).

4 Blijkens het scheepssoldijboek van Coxhorn.

- De schipper en trompetter op Coxhorn wonnen resp. 80 en 18 gulden ter maand, op de in hetzelfde jaar voor de Kamer Amsterdam uitgezeilde schepen Gaasperdam en Cornelia bedroeg het maandgeld voor de schippers 66 en 72 gulden en voor de trompetters 16 gulden. 
kwamen hun gages geheel overeen met hetgeen het scheepsvolk toen ter tijd op de gewone Oostinjevaarders placht te verdienen. ${ }^{1}$

Aleer zij de reis naar China aanvaardden hadden de negotiebedienden en scheepsoverheden van de Bewindhebbers een instructie ontvangen, waarnaar zij zich gedurende de expeditie zoo te water als te lande moesten gedragen. In de eerste plaats werd hun de naleving opgelegd van den artikelbrief der Compagnie; van de instructiën in 1649 vastgesteld voor den Scheepsraad en den Breeden Raad - met zoodanige wijzigingen wel te verstaan als deze bijzondere reis vorderde; ${ }^{2}$ en in het algemeen van alle andere instructiën, orders en resolutiën op het stuk van de zeevaart, de boekhouding enz., welke de Compagnie gewoon was aan haar schepen mede te geven. Gedurende de reis moesten de beide schippers in gemeen overleg de seinen beramen en aan den Scheepsraad ter goedkeuring voorleggen. Bij hen en de andere scheepsofficieren zou uitsluitend het bestuur van hun onderhebbenden bodem berusten, zonder eenige de minste medezeggenschap van de negotiebediendens. Uitgezonderd alleen aan de Kaap, waar zij zich zoo op de uit- als thuisreis van drinkwater en andere verversching mochten voorzien, was het den schepen verboden om onderweg ergens aan te loopen, tenzij zij er door den uitersten nood toe werden gedwongen, waarvan naderhand bij deugdelijke bewijzen zou moeten blijken. Zooveel doenlijk hadden de schepen gecombineerd te varen, kwam het te gebeuren dat een hunner "door ramp of ander zwaar toeval " achterbleef, en bestond er geen waarschijnlijkheid meer dat het binnenkort zou in staat zijn om te volgen, zoo zou zijn makker het alle mogelijke hulp moeten toebrengen en daartoe vertoeven of het inwachten, hetzij aan de Kaap hetzij ter hoogte van Bantam, den tijd van vier weken of zooveel korter of langer als dat zonder gevaar en zonder de reis naar China geheel te verliezen gedaan kon worden. Was echter de ramp zoo groot of had de storm de bodems zoo ver uit elkander geslagen dat zij ten eenenmale van elkaar waren verstrooid geraakt, dan mocht het andere schip zijn reis vervolgen en op de plaats van bestemming zijn eigen lading inkoopen. Het beleid van den handel in China werd bij de instructie geheel opgedragen

1 Blijkens het scheepssoldijboek van Coxhorn.

2 De wijzigingen hadden alleen betrekking op de samenstelling van den Scheepsraad en Breeden Raad. 
aan de kooplieden of de supercarga's en boekhouders, gelijk zij van ambtswege heetten. $\mathrm{Zij}$ zouden alle inkoopen moeten doen met meerderheid van stemmen, te beslissen hebben over het geven van geschenken aan de Chineesche grooten en mandarijnen, en samen met de scheepsoverheden moeten toezien dat alle ingekochte koopmanschappen naar behooren in de schepen werden afgeladen in zoodanige fustage of emballage als hun aard vereischte. Op den boekhouder of jongsten koopman van ieder schip rustte meer in het bijzonder de taak om van elke ingekochte partij boek te houden niet alleen, maar tevens in een resolutieregister de redenen aan te teekenen die tot het doen van den koop en het besteden van den bepaalden prijs hadden geleid. Ook moest hij een "ordentelijk dagregister» opstellen "van alles wat aan land passeerde alsmede van de lading der goederen en alles wat er binnen scheepsboord passeerde». Eindelijk had zoowel hij als de Tweede supercarga ten aanzien van het ontvangen en afleveren van Compagnie's goederen de orders na te komen van den Eersten supercarga van hun schip. De bewaring der medegegeven contanten lieten de Bewindhebbers ter verantwoording van de schippers, die echter gehouden waren daaruit aan de negotiebediendens van hun bodem tegen quitantie zooveel geld af te geven als deze tot den inkoop van koopmanschappen of voor andere behoeften zouden vorderen. In China liggende hadden de scheepsoverheden wel ernstig zorg te dragen dat zij niet allen tegelijk aan wal gingen maar dat op zijn minst een van de schippers, opper- en onderstuurlieden aan boord bleef om acht op de schepen te nemen, alsmede dat er alsdan evengoed wacht werd gehouden als in volle zee teneinde zoonoodig altoos in staat van verdediging te zijn. Met hetzelfde oogmerk werden de schippers gelast de chaloepen steeds wel te bemannen en te bewapenen en tot bewaring der factorij of loge, als er te Canton een mocht worden opgericht, , zooveel manschappen af te zonderen als de kooplieden noodig oordeelden. Buiten die factorij zou niemand, officieren evenmin als matrozen, mogen logeeren "op poene van straffen na exigentie van zaken». Indien de handel niet te Canton kon gedreven worden, gaven de Bewindhebbers vrijheid "om naar Amoy te zeilen, bijaldien de kooplieden zulks mochten goedvinden om te zien of Compagnie's negotie aldaar beter zou kunnen voortgezet worden . Maar deed zich het geval voor dat de Chineezen 
bezwaar maakten de onzen ten handel toe te laten en bij hun weigering volhardden, zoo zoude men met de eerste gelegenheid naar Batavia moeten vertrekken, waar de schepelingen en contanten ter beschikking van Gouverneur-Generaal en Raden zouden komen te staan, en de negotiebediendens zich met behoud van gage op de eerstuitzeilende schepen naar Nederland moesten inschepen. ${ }^{1}$

Onderwijl de Coxhorn met een ballast van 67,250 pond handlood en een lading van bij de drie ton aan zilveren muntspeciën, ${ }^{2}$ reeds de wateren doorkliefde van den Atlantischen oceaan, werd zijn makker Bừen maar aldoor belet in zee te steken: op het laatst van Januari lag het schip nog steeds opgesloten door het ijs in de haven van Medemblik. ${ }^{3}$ Aangezien de tijd nu zooverre was verloopen dat de reis naar China "niet dan met groot gevaar» meer ondernomen kon worden, ${ }^{4}$ besloten de Bewindhebbers in overleg met de andere Kamers der Compagnie Buren niet meer te laten uitgaan maar op te leggen en de contanten, die men er voor bestemd had, tot nader te bewaren. ${ }^{5}$

Wat Coxhorn betreft, na aan de Kaap, waar het op 28 Maart binnenviel, ${ }^{6}$ verversching ingenomen en een tijdlang op het zusterschip te hebben gewacht, ${ }^{7}$ ging het den 21 April van uit de Tafelbaai weder onder zeil, ${ }^{8}$ kwam op 24 Juni onder de kust van Java, zag den 29 Juli het land van China aan den

1 Instructie voor de koopluiden, schippers en verdere scheepsoverheden, die van hier naar China staan af te gaan, vastgesteld bij resol. Kamer Amsterdam 15 Nov. 1728.

${ }^{2}$ Blijkens een opgaaf in de papieren van het schip Coxhorn voorkomende. De contanten, uit Compagnie's kas medegegeven, vertegenwoordigden volgens die opgaaf een waarde van 299.949 gulden 8 stuiver zwaar geld en bestonden in 2400 marken Mexikaansche realen, 2000 marken Pilaren en 60.493 ducatons.

3 Resol. Kamer Amsterdam 31 Januari 1729.

${ }^{4}$ Als voren. Het gevaar bestond natuurlijk hierin dat Buren te laat onder de keerkringen zou arriveeren om den gunstigen mousson aan te treffen en dus zijn reis naar China zou moeten missen.

5 Resol. Kamer Amsterdam 31 Januari, 10, 17 en 21 Febr. 1720. Blijkens laatstgenoemde resolutie hadden de Bewindbebbers voor Buren een lading in Mexikanen, Pilaren en ducatons gereed ter waarde van 300.050 gulden 12 stuiver.

6 Brief van den supercarga de Jongh aan de Kamer Amsterdam 13 April 1729 (Papieren Coxhorn).

7 Resolutie Scheepsraad 11 April 1729 (als voren).

8 Notitieboek van Compagnie's uitgeloopen schepen (1688-1703). 
gezichtseinder oprijzen ${ }^{1}$ en liet eenige dagen na dien, op 2 Augustus 1729, voor Macao het anker vallen. ${ }^{2}$ De reis, die ten naaste bij acht maanden had geduurd, was over het geheel voorspoedig geweest; het schip had, voor die dagen merkwaardig genoeg, onderweg niet meer dan één opvarende door den dood verloren en maar drie zieken in het Kaapsche hospitaal moeten achterlaten. ${ }^{3}$

Des anderen daags gingen de carga's vroegtijdig aan wal om bij den Portugeeschen gouverneur te Macao volgens het gebruik hun opwachting te maken en vervolgens toebereidselen te treffen voor hun vertrek naar Canton. Met dat oogmerk lieten zij zich na afloop van de audiëntie bij den gouverneur naar de woning brengen van een Chineesch koopman, Gokonqua geheeten, van wien zij vernomen hadden dat hij te Canton een neef had wonen, die daar ter stede voor een van de voornaamste en eerlijkste kooplieden bekend stond en, naar men zeide, grooten invloed bezat zoowel bij het hoofd van den Chineeschen douanedienst of zoogenaamden hoppo ${ }^{4}$ als bij andere aanzienlijke mandarijnen. De bejegening, ten huize van hun nieuwe kennis ondervonden, konden de carga's niet beter wenschen; hij ontving hen niet alleen "zeer minzaam" maar noodigde ze ook aan zijn disch, beloofde hun voor de reis naar Canton aan een vaartuig te zullen helpen en aan een pas, - geen Europeaan mocht namelijk zonder een verlofbrief van de Chineesche douane de Cantonrivier op- of afvaren, ${ }^{5}$ - en stapte, toen die gereed waren,

1 Blijkens het finantieel journaal van Coxhorn (in het scheepssoldijboek) werd op die beide dagen aan een paar schepelingen een premie toegelegd "voor het zien van het land van Java" en "voor het zien van het land van China."

${ }^{2}$ Dagregister gehouden door den boekhouder te Canton 2 Aug. 1729 (Papieren Coxhorn).

3 Blijkens het scheepssoldijboek van den bodem.

4Le Hoppo..... était le titre donné par erreur par les étrangers au haut fonctionnaire placé à la tête des douanes maritimes qui, représentant le ministère des finances, Hou-Pou, était désigné par ce nom déformé", Cordier, Les marchands hanistes de Canton, T'oung pao, II, 3 p. 281. - „The Hoppo, an officer of the Imperial Household, had to purchase by a heavy fee a five years' tenure of the monopoly of collecting the native and foreign eustoms duties of Canton, and on his return to Peking, he was invariably squeezed like a sponge by the Imperial Household, E. J. Eitel, Europe in China, p. 4.

${ }^{5}$ Geen Europeaan mocht zonder pas de Bocea Tigris, een nauwen doortocht in de rivier, passeeren zonder een pas van de Chineesche douane te Macao of te Canton, Dagregister van de carga's te Canton 4 Aug. 1765, Description of the City of Canton, Canton 1839, p. 106. 
des namiddags te zamen met de carga's mede aan boord om ze tot Canton te vergezellen en hun bij de aankomst aldaar verder van dienst te wezen. $\mathrm{Na}$ een tocht van omtrent drie uur, waarop zij zich naar lands gebruik achtereenvolgens aan de drie douaneof tjaphuizen in de rivier moesten laten visiteeren, ${ }^{1} \mathrm{kwam}$ het gezelschap nog dien eigen avond om ongeveer 8 uur te Canton aan. Zij namen hier aanstonds hun intrek bij den neef van hun reisgenoot, Tanhonqua, die ze met zijn compagnon Chinqua ontving "met zeer veel vriendelijkheid en betuiginge van blijdschap over hun gelukkig arrivement.» Nauwelijks waren zij daar een uur in huis geweest of verscheidene kooplieden uit de stad, inmiddels door Tanhonqua van hun komst verwittigd, kwamen hen niettegenstaande het vrij late uur verwelkomen. ${ }^{2}$

Het trof voor de onzen gelukkig dat de beide Cantonsche kooplieden, bij wie zij door hun Macaosche kennis waren ingeleid, van wege de goede behandeling die zij te Batavia herhaaldelijk ondervonden hadden voor de Hollanders zekere genegenheid gevoelden, en zelfs eenigermate met de Hollandsche taal vertrouwd waren. ${ }^{3}$

Hunne hulp is dan ook den carga's van groot nut geweest. Toen dezen, om iets te noemen, den wensch te kennen gaven om een spoedige audientie bij den hoppo te hebben, ten einde zoo dra mogelijk te weten of het hun vrij zou staan den handel even onbelemmerd te drijven als de andere Europeanen inzonderheid de Engelschen, gaf Tanhonqua hun den practischen raad om "den eersten en oppersten tolk van alle Europeesche natiën», die volgens zijn zeggen een groot favoriet van den hoppo was en dien hij ondertusschen al bij zich had laten noodigen, in stilte een geschenk toe te zeggen, wat zijn uitwerking niet zou missen, zeide hij. Dien wenk ter harte nemend, beloofden de carga's den tolk een geschenk in geld, ${ }^{4}$ indien hij een spoedig gehoor voor hen wist te verwerven, met het gelukkige gevolg dat zij den volgenden morgen al vroeg uit zijn eigen mond de tijding kwamen te hooren, dat hij hun komst

1 Blijkens de Cassarekening van de carga's (Papieren Coxhorn).

2 Dagregister der carga's 2-4 Augustus 1729 (Papieren Coxhorn).

3 Volgens hun in het Hollandsch geschreven brieven aan de Kamer Amsterdam van 29 Dee. 1729 en 20 Januari 1730 (Papieren Coxhorn).

- Blịkens de Cassarekening schonken de carga's aan „den eersten en oppersten taalman van alle Europcesche natiën bij den groot-mandarijn hoppo" ter verkrijging eener spoedige audientie 50 Tael. 
bij den hoppo had aangediend en dat deze hen voor den middag zou ontvangen. ${ }^{1}$

Tegen 10 uur begaven zich de onzen, op 's lands wijs in draagstoelen gezeten; naar het paleis van den hoppo, waar zij na een oogenblik wachtens door de tolken werden binnengeleid * in een zeer groote zaal, alwaar de mandarijn hoppo was gezeten naar de wijze der Chineesche grooten op een zeer breede bank met een alcatief ${ }^{2}$ overdekt. Ter wederzijde van de zaal stond een rij van Tartaarsche soldaten. Den hoppo op onze wijze gegroet hebbende (dus verhalén de carga's verder), zoo wierden ons onze zitplaatsen aangewezen op drie stoelen, dewelke aan de linkerhand van den hoppo op een tamelijken afstand stonden. Gezeten wezende zoo lieten wij, eenige complimenten nog voorafgaan zijnde, door den tolk te kennen geven dat wij te dezer plaats waren gekomen evenals andere Europeesche natiën om te negotieeren en te dien einde hem, hoppo, permissie kwamen verzoeken om zulks vrij en liber te mogen doen op den voet als aan andere Europeesche handelaars wierd ververgund, zoowel rakende de in- en uitgaande rechten als omtrent het lossen en laden der goederen, al hetwelke de hoppo volkomentlijk toestond met belofte ons daarvan een behoorlijk schriftuur te verzorgen. Vervolgens betuigde hij met onze komst zeer wel in zijn schik te wezen als hebbende altoos van de Hollanders met zeer veel reputatie hooren spreken. Tusschen beide wierd ons een kopje thee geschonken, hetwelk genuttigd hebbende bedankten den hoppo voor de genoten gunst en namen daarop ons afscheid. ${ }^{3} \mathrm{Na}$ afloop van de audiëntie gaven de carga's den kapitein van het schip, dat nog altoos voor Macao ten anker lag, onmiddellijk van den gunstigen uitslag kennis en schreven hem dat hij gerust de rivier kon opvaren tot op de reede van Wampoo. ${ }^{4}$ Vervolgens uitziende naar een loge of factorij huurden zij des anderen daags het achterhuis van een Chineesch koopman, waar zij aanstonds eenige timmerlui, metselaars en koelies aan den arbeid zetten om het gebouw ten

1 Dagregister als voren 4 en 5 Aug. 1729.

2 Tapijt.

3 Dagregister als voren 5 Aug. 1729.

4 Huampo, gewoonlijk Wampoo genoemd, was de ankerplaats waar alle Europeesche schepen zoolang hun handelstijd duurde bleven liggen, Peter Osbeck, Reise nach Ostindien und China, Rostock 1765, S. 152. 
eerste tot een geschikte woning in te richten. ${ }^{1}$ Binnen kort waren dezen met het herstellingswerk zoover gevorderd dat de carga's met den schipper en een wacht van scheepsvolk onder het bevel van den derdewaak de factorij konden betrekken. ${ }^{2}$ Tezelfder tijd bekwam de schipper van den hoppo verlof om tegen betaling van de grondhuur te Wampoo een banksaal of bamboezen loods op te slaan tot berging van de victualie, de waarlooze scheepsgoederen en dergelijke meer. ${ }^{3}$

Intusschen hadden de onzen, alweder op raad van hun Chineeschen gastheer, zorg gedragen zich door geschenken de gunst te verzekeren van de twee voornaamste "pay de cases" of huisdienaars van den hoppo, met wie men in het lossen en laden het meeste te doen had en wien de Europeesche kooplieden, om tegen verhindering en vertraging gewaarborgd te zijn, ter dege de handen plachten te zalven. ${ }^{4}$ Dat zij bij den hoppo zelf eveneens op welwillendheid mochten rekenen, daarvan hadden zij een bewijs ontvangen door de schenking van een levend hertebeest, dat hij hun aan huis liet bezorgen. ${ }^{5}$

Toen met het een en het ander de weg was gebaand, gingen de carga's over tot het eigenlijke negotiewerk. Den 9 Augustus, juist een week na hun aankomst, deden zij bij een Chineesche firma, een van de zes koopmanshuizen welke "gepermitteerd waren om met de Europeesche natiën te handelen, ${ }^{6}$ hun eersten

1 Het was in China namelijk zoo goed als algemeene regel dat de huurder van een huis de kosten van reparatiën droeg, Dagregister der earga's te Canton 17 Mei 1768.

${ }^{2}$ Dagregister 9 en 24 Aug. 1729.

s Dagregister 16 Aug. 1729, en Specificatie van alle onkosten door den schipper tijdens het aanwezen van de Coxhorn in China betaald (Papieren Coxhorn). Zulk een banksaal van bamboestijlen en matten opgetrokken bezat elk schip te Wampoo, zij diende niet alleen tot pakhuis van alles wat men aan boord kwijt wilde wezen maar ook om het voor de victualie benoodigde vee te slachten, vgl. Osbeck, a. w. S. 153; C. F. Noble, A voyage to the East Indies in 1737 and 1748, London 1762, p. 294; Olof Toreen, Ostindische Reise nach Suratte, China ete., Rostoek 1765, S. 483; Carl Gustav Ekeberg, Ostindische Reise in den Jahren 1770 und 1771, Dresden-Leipzig 1785 , S. 77 .

4 Resol. carga's 8 Aug. 1729. Aan den eersten pay de case werd geschonken 1 stuk rood laken, 2 groote spiegels en 2 stuk ras de marocq, aan den tweeden, die een neef van den hoppo was, een éénsteens diamanten`ring.

${ }^{5}$ Dagregister 8 Aug. 1729.

6 Geen Chineesch koopman mocht namelijk met de Europeanen handel drijven zonder een speciale verlofeeel of "hangtjap" van de overheid (Rapport 
inkoop van thee. Een goede week later deden zij er wederom een. Beide keeren werd met de verkoopers een contract aangegaan, waarbij dezen zich verbonden om de overeengekomen partij binnen 100 resp. 110 dagen aan boord te zullen leveren op hun eigen risico en vrij van alle kosten van kisten, lood, pakken, hoppo's- en keizersrechten en verdere ongelden meer. ${ }^{1}$

Daarmede was voorshands de theecampagne, als men zoo spreken mag, voor een tijdlang afgeloopen. Trouwens, wat men in de eerste plaats behoefde, was niet thee, een artikel uitteraard van wege zijn lichtheid al zeer ongeschikt om het eerste te worden ingescheept. Zou het schip stevig genoeg op het water liggen, "niet te rank» zijn zooals de zeemansterm luidde, dan diende er tot onderlaag een koopmanschap te worden ingenomen van zwaarder gewicht. Hiertoe nu kwam geen andere waar eerder in aanmerking dan porcelein, dat niet alleen een voortreffelijken ballast uitleverde maar waarop tevens in Europa een aardige winst viel te behalen. De carga's lieten derhalve reeds vroegtijdig de kist van boord opkomen, ${ }^{2}$ waarin de monsters waren geborgen van de sortimenten, die door de Bewindhebbers werden verlangd. Weliswaar moesten zij bij hun eersten rondgang in de winkels en pakhuizen ondervinden dat er onmogelijk porcelein te bekomen was overeenkomende met de monsters, hetzij wat hoedanigheid hetzij wat hoeveelheid betrof, doch daar zij nu eenmaal «tot onderlaag van hun bodem noodzakelijk porcelein moesten hebben, " stapten zij over de bezwaren heen en sloten een paar koopen, waarmede naar hun raming al een goed getal van kassen zou vol geraken, op voorwaarde dat de douanerechten en alle andere onkosten, met uitzondering alleen van die van het maken van de kassen en hetgeen daartoe behoorde, gedragen zouden worden door de verkoopers ${ }^{3} \mathrm{Op}$ de

van de Cantonsche carga's aan Gouverneur-Generaal en Raden 4 Januari 1765). De zes gepermitteerde koopmanshuizen zullen te zamen den zoogenaamden Cohong hebben uitgemaakt, die in 1720 in plaats van den eenigen keizerlijken koopman (Emperor's Merchant) ingesteld was om den handel met de vreemdelingen te voeren, vgl. Eitel, Europe in China, p. 5. Volgens P. Auber, China an outline of its government, laws and policy, p. 155, namen de Chineezen in 1720 het besluit om zich te vereenigen tot een lichaam, Cohong geheeten, teneinde gemeenschappelijk de prịjzen te bepalen waarvoor de Europeesche goederen aan hen zouden moeten verkocht worden.

1 Resol. carga's 9 en 19 Aug. 1729.

2 Dagregister 16 Aug. 1729.

s Resol. carga's 26 Aug. 1729. 
gedurig inkomende berichten, dat het naar boord afgezondene telken male ontoereikende bleek om de onderlaag gevuld te krijgen, gingen de carga's tot half November toe met het inkoopen van porcelein voort. ${ }^{1}$ Ofschoon zij op het laatst van October zoo gelukkig waren op eenige fraaie assortimenten van wit goed de hand te kunnen leggen - "het eerste en eenigste van die kleur, dat zij te zien kregen, ${ }^{2}-$ schijnen zij met de porceleinnegotie maar matig te zijn geslaagd. Fijne, mooie waar viel schaarsch, ${ }^{3}$ en van zulke, die met de medegebrachte monsters overeenkwam, was weinig of niets verkrijgbaar. ${ }^{4}$

Nauwelijks waren de carga's op 25 October voor het grootste gedeelte klaar gekomen met het porcelein, of den volgenden dag ontvingen zij van de leveranciers, bij wie zij in Augustus hun eersten inkoop van thee hadden gedaan, bericht dat dezen voornemens waren een begin te maken met het afpakken en hen daarom verzochten des anderen daags het afwegen bij te komen wonen van de tarra van de kassen of pakkisten, welke zij overeenkomstig het koopcontract hadden laten gereed maken. ${ }^{5}$ Nadat het "tarren" onder hun eigen oogen behoorlijk was verricht, ${ }^{6}$ begaven de onzen zich den daarop volgenden dag wederom naar de leveranciers, ditmaal om bij het pakken tegenwoordig te zijn. Terwijl de koelies van 's morgens vroeg tot 's avonds laat, telkens twee man te gelijk in iedere kas, de thee met zwaren, inspannenden arbeid vasttrapten, hielden de carga's bij het openen en overstorten van de kanassers of korven, waarin zij werd aangebracht, nauwlettend toezicht of zich onder de geleverde waar geen slecht goed bevond. 7 Vervolgens werden de kassen gesloten, met papier beplakt ${ }^{8}$ en een dag of wat later

1 Dagregister 28 Sept., 9 en 25 Oct., 14 Nov. 1729; Resol. carga's 13 Oet. en 11 Nov. 1729.

2 Resol. carga's en Dagregister 25 Oct. 1729.

s Dagregister 28 Sept. 1729.

‘ Resol. carga's 26 Aug. 1729, Dagregister 28 Sept. en 12 Oct. 1729.

5 Dagregister 26 Uct. 1729.

6 Dagregister 27 Oct. 1729.

7 Dagregister 28 Oct. 1729. Van het $\mathrm{z}$ ware werk van het theetrappen spreekt Peter Osbeck, Reise nach Ostindien und China, Rostock 1765. S 209 aldus: "Ein Chineser steigt in eine solche Kiste und tritt den Thee, so wie er aus den Korben hinein geschüttet wird, fest zusammen, welches eine so beschwerliche Arbeit ist dasz, ohneracht ein solcher Kerl fast ganz entkleidet ist, ihm doch der Schweisz au den Füssen herunter läuft,"

8 Osbeck, a. w. S. 209. 
overgebracht naar de factorij, ${ }^{1}$ waar $\mathrm{zij}$ gewogen werden. ${ }^{2}$ Hetzelfde had plaats zoo vaak er weer een nieuwe partij kassen, gewoonlijk van 100 stuks, gereed gemaakt was, wanneer althans geen regenweder hen noodzaakte het afpakken uit te stellen. ${ }^{3}$ Had men aanvankelijk nagenoeg uitsluitend ordinaire thee of thee boei ingekocht, latèr sloeg men ook kleinere partijen van fijnere soort als congo en heyson in, die om de lading van het schip des te beter te stuwen en meteen tot opvulling van de in het scheepsruim opengebleven vakken te kunnen dienen, afgepakt werden hetzij in kassen van kleiner formaat hetzij in kanassertjes, welke laatste dan tot beter preserveering nog eens in matten werden benaaid. ${ }^{4}$

Toen hun in de tweede helft van December uit de van boord inkomende berichten bleek, hoe er geen koopmanschappen van eenigen omvang meer in het schip te bergen waren, besloten de carga's voor het vrij aanzienlijke kapitaal dat hun nog ter beschikking stond, zijdestoffen in te slaan en met dezen inkoop nam op 27 December 1729 hun handelsbedrijf in China een einde. ${ }^{5}$

Gedurende al die maanden bleef het schip Coxhorn ter reede van Wampoo, waar het in den namiddag van 11 Augustus was aangekomen, ${ }^{6}$ voor anker liggen. Niet zoodra had men den volgenden dag van zijn aankomst gehoord of een van de tolken kwam de carga's uit naam van den hoppo mededeelen, dat deze daags daarna volgens het bestaande gebruik den bodem zou laten meten om naar verhouding van de gebleken grootte

I Dagregister 29 Oct., 2, 12, 14, 16, 25 en 28 Nov., 7 en 18 Dec. 1729, Osbeck, t. a. p.

2 Als voren.

s Dagregister 27-30 Oct., 1, 2, 4, 5, 9, 11-16, 20, 23, 24-27 en 30 Nov., 1-4, 6-8 en 19 Dec. 1729. Resol. carga's 17 Dec. 1729. - Dagregister 31 Oct.: belet thee te pakken "door het gestadig regenen, hetwelk zeer schadelijk is voor de thee"; 10 Nov.: als voren; 23 Nov.: niets kunnen pakken "wegens de vochtigheid van het aardrijk door den regen van gister en eergister 't geen volgens het algemeen gevoelen der Chineezen zeer schadelijk voor de thee is."

4 Dagregister 9, 14, 15, 29 en 30 Nov., 6-8 Dec. 1729; Resol. carga's 17 Dec. 1729. - Blijkens het Dagregister werden op 14 Nov. ook 100 kanassers thee boei in ontvangst genomen, schoon deze soort, gelijk het Dagregister op 30 Nov. vermeldt, „zeer zelden of nooit in zulke kleine fust gedaan" werd.

5 Resol. carga's 26 Dec. 1729 en Dagregister 26 en 27 Dec. 1729.

6 Dagregister 12 Aug. 1729.

Dl. 73 
het bedrag vast te stellen van het verschuldigde tonne- of ankeragegeld. Persoonlijk, zoo liet de hoppo weten, werd hij door ongesteldheid verhinderd, maar hij had de taak overgedragen aan zijn eersten pay de case (dienaar) en verzocht derhalve om aan dien mandarijn "hetzelfde fatsoen , te willen bewijzen alsof hij in eigen persoon gekomen ware. ' Dientengevolge voeren de onzen den anderen ochtend al vroegtijdig aan boord, waar zij na eenigen tijd wachtens in den loop van den voormiddag den pay de case zagen opdagen met een grooten sleep van mandarijnen, schrijvers, tolken en meer ander personeel. Na het nuttigen van eenige ververschingen, gingen de mandarijnen aanstonds aan het werk "wordende (zooals het dagregister zegt) een lijn gespannen van den fokkemast tot aan den bezaansmast, ${ }^{2}$ waarlangs de lengte wierd gemeten, en de breedte langs een lijn, even voor den grooten mast op het dek van het eene boord tot het andere gehaald,. Toen men hiermede gedaan had, zoo verhalen de carga's in hun dagregister al verder, *tracteerden wij de voornaamste onder deze messieurs met verscheidene versnaperingen en wijn, waaraf zij om te toonen dat het haar wel smaakte niet alleen een goede quantiteit verorberden maar een groot gedeelte nog medesleepten in hunne vaartuigen, waarmede zij 's namiddags wonderlijk in hun schik over de aan haar betoonde beleefdheden weder naar Canton voeren. ${ }^{3}$

Van het oogenblik af dat zij voor Wampoo het anker uitwierpen plachten de schepen onderworpen te zijn aan de contrôle van den Chineeschen douanedienst. Aanstonds werden aan het schip een paar tolvaartuigen vastgemaakt, waarop zich eenige ambtenaren bevonden die daar gestadig de wacht bleven huuden opdat zonder hun voorkennis niets zoude worden in- of uitgescheept. ${ }^{4}$ Zonder een bijzondere verlofceel van den hoppo mochten geen personen noch goederen hoegenaamd van Canton naar boord of weder-

\footnotetext{
1 Dagregister als voren.

2 De voorste en achterste mast.

s Dagregister 13 Aug. 1729.

4 Sonnerat, Reize haar de Oost-Indiën en China, Leiden 1785-1786, blz. 185, vgl. ook Davis, China en de Chineezen, Amst. 1841, Dl. III blz. 298. Sonnerat, geboren 1745, bracht een groot deel van zijn leven door met reizen; van 1774-1781 reisde hij in China en Indië, hij vestigde zich ten slotte te Pondichery, in 1803 keerde hij naar Frankrijk terug. Brettschneider, Early researches into the flora of China, Journal of the North China Branch of the Royal Asiatic Society 1880 p. 128.
} 
keerig van boord derwaarts worden vervoerd. ' Dit paspoort in de wandeling tjap ${ }^{2}$ geheeten, moest onderweg achtereenvolgens worden vertoond aan de drie hoppo's- of tjapkantoren, ${ }^{3}$ kleine in de rivier op palen uitgebouwde huisjes, tegen wier buitenmuren de tolverordeningen waren aangeslagen en waarnaast een met Chineesche letters beschilderde vlag stond te wapperen. ${ }^{4}$ Wanneer bij de visitatie aldaar bleek, dat de medegevoerde goederen overeenkwamen met de bij het tjap gevoegde lijst, welke ò te Canton ò aan het wachtschip was opgemaakt, zoo werd de pas na aan de eerste twee kantoren, welke men voorbijkwam, te zijn afgestempeld, aan het laatste afgegeven, en kwam men onverlet door. ${ }^{5}$ Kwam echter aan het licht dat men iets meer medenam, dan werd zulks als smokkelwąar aangehaald en verbeurd verklaard. ${ }^{6}$ Voor sluikerij bestond dan ook bijna alleen gelegenheid wanneer men onder zijn eigen nationale vlag in een zoogenaamde kapiteinssloep voer, deze namelijk was van het betalen van in- en uitgaande rechten geheel vrijgesteld en mocht de tjaphuizen onverhinderd voorbijvaren. ?

Zoo dikwijls er dus in de factorij een partij thee of andere koopwaar voor verzending gereed lag of van boord proviand, contanten en dergelijke te ontbieden waren, was het eerste werk van de carga's hiervan door tusschenkomst van de in hun dienst staande tolken den hoppo te verwittigen, en het benoodigde tjap bij hem aan te vragen. ${ }^{8}$ Kort daarop verschenen alsdan de bedienden van den hoppo in de factorij om de af te schepen of aangebrachte goederen te visiteeren. ${ }^{9}$ In het eerste geval liep het werk meestal spoedig van stapel, want vermits de

1 Het dagregister van Coxhorn maakt herhaaldelijk gewag van tjappen, bij den hoppo aangevraagd om goederen naar Wampoo aan boord te mogen brengen of van het schip naar Canton op te laten komen. Vgl. verder Sonnerat, a. w. blz. 186.

2 Naar het opgestempelde zegelmerk (tjap).

3 In de cassarekening van Coxhorn worden zij de "drie mandarijnshuizen" genoemd.

4 Osbeck, a. w., S. 168; C. F. Noble; a. w. p. 397.

${ }^{5}$ Osbeck, a. w. S. $168,169,173$; Toreen, a. w. S. 483 ; Ekeberg, a. w. S. 85

6 Toreen, a. w. S. 483.

7 Osbeck, a. w. S. 168; Toreen, t. a. p.; Ekeberg, a. w. S. 85; Sonnerat, a. w. blz. 186.

8 Dagregister 15 en 19 Aug., 4, 7 en 21 Sept., 14 Oct., 2, 8, 12, 16 en 20 Nov., $1,9,13,16,22$ en 27 Dec. 1729.

9 Dagregister 16 en 21 Aug., 1 en 8 Sept., 6 en 15 Oct., 8, 18, 22 en 29 Nov., $10,14,15,17,24,25$ en 28. Dec. 1729. 
Chineesche leverancier gemeenlijk van hetgeen hij verkocht de rechten betaalde, schreef hij op elke kas of baal wat zij bevatte en onderteekende die verklaring met zijn stempelmerk. Stond de koopman te goeder naam en faam bekend, zoo onderzochten de hoppo'sbedienden alleen of de kas na de sluiting niet meer open was geweest om de goederen, welke hij had aangegeven, tegen andere te verwisselen, en brachten vervolgens met een verfborstel of zegelstempel op de kas hun tjap aan, tot teeken dat zij was nagezien en vrijelijk kon afgescheept worden. ${ }^{1}$ Ook als de waren vervolgens met de voor dat doel afgehuurde Chineesche champans, - groote overdekte schuiten zonder kiel en in gedaante sterk op een baktrog gelijkende ${ }^{2}$ - de rivier af werden gevoerd naar Wampoo, ging hét met de contrôle niet gestreng toe. De gezagvoerder liet aan de drie tolhuizen eenvoudig het tjap en de lijst van de lading zien, welke laatste dan aan elk tolhuis door de beambten werd afgeteekend. De kassen zelf werden, ofschoon zij er toe bevoegd waren, zelden of nooit door de beambten geopend. Zij vergenoegden żich met na te zien of hun getal overeenstemde met dat van de lijst en vergewisten zich slechts of iedere kas behoorlijk was voorzien van het opgedrukte tjap van de bedienden van den hoppo. Wanneer ten slotte de lichterschuit langszij het schip lag, hielden verscheidene douanebeambten op de overlading van de goederen toezicht. ${ }^{3}$ Minder gemakkelijk daarentegen schijnt men met de visitatie geweest te zijn als er iets van boord in de factorij binnenkwam. Toen de onzen bijvoorbeeld omstreeks half Augustus eenige provisiën hadden laten opkomen alsmede de kist die de medegegeven monsters bevatte van de verlangde porceleinen, keken de bedienden van den hoppo het een en het ander ten zorgvuldigste na "om te zien of er ook koopmanschappen onder verborgen waren, teekenende voorts alles op hoe weinig en hoe gering dat het ook was. ${ }^{*}$ Het is waar, het was toen de eerste maal dat zij in de Hollandsche factorij kwamen visiteeren, het mag zijn dat zij naderhand wat minder scherp zijn opgetreden. ${ }^{5}$

1 Sonnerat, a. w. blz. 189.

2 Osbeck, a. w., S. 163.

3 Sonnerat, a. w., blz. 189.

4 Dagregister 16 Aug. 1729.

${ }^{5}$ Het dagregister, dat op 21 Aug., 1 en 8 Sept., 15 Oct., 22 Nov. en 17 Dec. 1729 nog meer zulke visitaties van aangebrachte goederen vermeldt, gewaagt ten minste van verdere bijzonderheden van dien aard niet meer. 
Hoe groot het bedrag is geweest van de rechten, welke gevorderd werden van de aangevoerde of afgescheepte goederen, laat zich niet meer nagaan. De uitgaande rechten toch kwamen, gelijk gezegd, gewoonlijk ten laste van de Chineesche leveranciers, ${ }^{1}$ en waren dus begrepen in de prijzen, die dezen voor hunne waren bedongen hadden. Slechts zooveel staat vast: met inbegrip van het tonne- of ankergeld hebben de carga's van Coxhorn voor paspoorten, tjappen, douane- en visitatierechten een som uitgegeven van ruim 3100 Tael. ${ }^{2}$

Bij het werk, aan den afscheep en aanvoer van de goederen verknocht, ondervonden de carga's veel hulp van de Chineesche tolken, die zij bijkans vijf maanden lang in dienst hadden. $\mathrm{Zij}$ belastten zich blijkbaar met het afhuren van de champans, wanneer de onzen er een noodig hadden, bezorgden de benoodigde tjappen en fungeerden als tusschenpersonen tusschen de factorij en het kantonr van den hoppo. ${ }^{3}$ Verder behoorde het tot hun taak om, zoo dikwijls de bedienden van den hoppo in de factorij een visitatie verrichtten, daarbij tegenwoordig te zijn en een lijst van de verschuldigde rechten op te maken, welke op het hoppo'skantoor als grondslag voor de invordering diende. ${ }^{4}$ Dat zij door de Chineesche overheid tegelijkertijd min of meer als dwarskijkers in de factorij werden gebruikt, spreekt van zelf. ${ }^{5}$

Hoezeer de afgifte van de aangevraagde tjappen in den regel

1 Zie hiervoor blz. 79. Het blijkt trouwens ook uit de contracten voor de thee- en porceleinleveranties bij resolutie der carga's aangegaan op 8 en 26 Aug., 28 Sept. en 25 Oct. 1729.

2 Blijkens hun cassarekening, waar die uitgaven aldus worden gespecificeerd : „per zooveel na gedane meting onze bodem voor onze charter (heeft) moeten betalen Tael 3015.8.8.0; per zooveel voor 3 paspoorten om naar Canton op te mogen gaan aan den mandarijn tot Macao hebbe moeten betalen T. 38.8.8.0; per vijff malen visitatie der goederen door de mandarijnen T. 29 ; per de gereehtigheid daarvoor (n.l. voor de champans om goederen van en naar boord te brengen) van 3 -hoppo'shuizen T. 5.5.2.0; per het bezichtigen van de ontladene goederen zoo mede geld en lood T. 18.0.0.0; per 10 tjappen T. 4.6.0.0."

3 Blijkens het dagregister op 20 en 21 Sept., 2 en 20 Nov. en 29 Dec. 1729.

4 Davis, China en de Chineezen, Amst. 1841, blz. 299; The Fan-Kwae or Canton before treaty days by an old Resident, London 1882, p. 50 .

5 Vgl. Dagregister der Cantonsche bediendens 6 Mei 1763: de tolken hangen geheel af van de fiadors en ,zoo spreekt het van zelf dat (zij) hen van alles verwittigen wat in de factorị van zoodanige Europeëische natie als zịj bedienen voorvalt," 
spoedig genoeg plaats had, gebeurde het nu en dan toch dat de hoppo om de een of andere reden zwarigheid maakte. Toen de carga's, om een paar gevallen te noemen, den $21^{\mathrm{n}}$ September een van de tolken naar zijn kantoor zonden om een tjap tot afscheep van porcelein, vernamen zij van de Chineesche kooplieden, dat er tusschen hen en den hoppo een geschil was opgerezen over zekeren eisch van geld, waarin zij niet van zins waren zoo schielijk te bewilligen, en aleer dat uit den weg was geruimd, zeiden $\mathbf{z i j}$, zou er van het afgeven van het tjap gewis niets komen. $\mathrm{Zij}$ troostten er de onzen mede dat het geschil bìnnen drie à vier dagen zeker afgedaan zou zijn en, voegden zij er bij, de Engelschen hebben er nog meer door te lijden dan gij, Hollanders, want die hebben nu ten gevolge van deze oneenigheid alreeds tien tot twaalf dagen te vergeefs gewacht op hun tjap. ${ }^{1}$ Toen er een week na dien nog maar steeds geen schot in de zaak kwam, gaven twee van de voornaamste kooplieden aan onze carga's den raad om gezamenlijk met die van de Engelsche Compagnie bij den hoppo op audientie te gaan en hem hun ongenoegen te kennen te geven. ${ }^{2}$ Beide . Engelschen en Hollanders, vervoegden zich nu bij den eersten pay de case of dienaar van den hoppo, waar zij hun beklag deden en van den pay de case de toezegging ontvingen dat hij hun belangen aan den hoppo zou voordragen en ze den volgenden morgen van den uitslag zou verwittigen. ${ }^{3} \mathrm{Zij}$ moesten dien morgen echter tot hun nieuwe teleurstelling vernemen dat het verzoek van geen de minste uitwerking was geweest. ${ }^{+} \mathrm{Niet}$ beter slaagde een bezoek, een dag of vijf later door de Engelsche carga's aan het paleis van den hoppo gebracht: tegengehouden door de wachthebbende soldaten, moesten zij van daar terugkeeren zonder zelfs den hoogen mandarijn gezien of gesproken te hebben. ${ }^{5}$ Eindelijk, in de eerste week van September, ontving men in onze factorij de tijding dat het geschil was vereffend en het langverwachte tjap den volgenden ochtend zou bezorgd worden, zooals inderdaad ook geschiedde. ${ }^{6}$ Een

1 Dagregister 21 Sept. 1729.

2 Als voren 28 Sept. 1729.

3 Als voren 28 Sept. 1729.

4 Als voren 29 Sept. 1729.

s Als voren 4 Oet. 1729.

6 Als voren 5 en 6 Oct. 1729. 
goede maand verder in den tijd rezen nieuwe moeilijkheden. Den $2^{\text {n }}$ November kwamen de tolken vertellen hoe de hoppo verklaard had voor de destijds ter afscheping gereed liggende thee geen tjap te zullen verstrekken, zoolang hem niet het verschuldigde scheepsmetings- of tonnegeld ten volle was uitbetaald. Onze carga's voerden hun tegemoet dat, zoodra de hoppo andermaal een tjap geliefde te verleenen om contanten van boord te laten afhalen, hem het restant van dat geld ten eerste zou worden ter hand gesteld. ${ }^{1}$ Terwijl zij maar aldoor met ongeduld zaten te wachten, deelde hun in den loop van de naaste week de Chineesche koopman Chinquan mede, dat hij en zijn compagnon Tanhonqua bij den hoppo een goed worrd voor hen hadden gedaan maar dat deze onverzettelijk op zijn eisch was blijven staan, weshalve hij en zijn compagnon om het struikelblok van de baan te schuiven te rade waren geworden het bewuste restant van het scheepsmetingsgeld voor de onzen voor te schieten. Het gevolg was dat daags daaraan de afscheping onverhinderd door kon gaan. ${ }^{2}$

Waarschijnlijk, ook al vindt men ze nergens met dezen naam betiteld, waren die twee Chineesche kooplieden de fiadors van de Hollanders, hadden zij zich met andere woorden tegenover de overheid te Canton persoonlijk aansprakelijk gesteld zoowel voor het goed gedrag van de onzen als voor de betaling van alle door hen verschuldigde fooien en rechten, ${ }^{3}$ immers een oud gebruik bracht mede dat geen Europeanen zonder zulke borgen te Canton handel mochten drijven. Hoe het in zwang was gekomen wordt door latere Compagniesbediendens van de Cantonsche factorij als volgt uiteengezet: "de eerste Europeesche schepen, die hier te Canton ten handel kwamen, deden zulks op persuasies van Amoysche kooplieden,${ }^{4}$ die zich vooraf reeds

1 Als voren 2 Nov. 1729.

2 Als voren 7 en 8 Nov. 1729.

3 Osbeck, a. w., S. 180; Davis, a. w. III blz. 299; Description of the eity of Canton, Canton 1839, p. 107. De term fiador is het Portugeesche woord voor borg.

4 "Deze haven (Canton) heeft nog niet lang bij de Compagnie (de Engelsche O. I. Compagnie nl.) in aanzien geweest (zoo leest men bij Carel Lockyer, Beschrijving van den koophandel in Oostindiën van 1711, Amst. 1753, blz. 53), maar de Madrasse kooplieden hebben dezelve voor dezen veel jaren lang boven die van Amoy geprefereerd, waar zij al te sporelooze eischen, lasten en mishandelingen van de mandarijns moesten uitstaan." Ook Osbeck, a. w. S. 181, getuigt dat de handel van de Europeanen zich indertijd van Amoy naar Canton had verplaatst, 
hier ter woon hadden begeven. Intusschen bij de mandarijnen naricht inloopende van de komst van schip of schepen, wilden die niet dat dezelve binnenkwamen, vreezende daar rooverije of verraad achter schuilde, hetgeen de gedachte kooplieden, die de carga's en de kapitein die er op waren van voorheen kenden, uit zucht tot winst zich deed borg stellen en verbinden voor de trouw en het goed gedrag dezer vreemdelingen, in zooverre dat zij zich zelf onderwierpen lijfs- of levensstraffen te lijden, die deze vreemdelingen door moord of andere euveldaden mochten komen te meriteeren, in zooverre de mandarijnen niet geraden of zich in staat vonden dezelve direct daarover te attaqueeren. Nagaans wierd de komst van Europeesche schepen algemeener en de Europeanen meer bekend. Evenwel houdt de Cantonsche regeering gemakshalve en uit meer andere inzichten het fiadorschap nog aan., ${ }^{1}$ Naderhand, ja mogelijk zelfs al in den tijd waarvan wij nu spreken, werd blijkens het aangehaalde bericht «aan geen tolken of compradors ${ }^{2}$ het permissietjap door de mandarijnen afgegeven tenzij op verzoek van de fiadors of borgen; en (aldus gaat het bericht voort) daar de laatsten voor het gedrag der Europeanen aansprakelijk zijn, zoo spreekt het van zelve dat de eersten van hen geheel moeten af hangen en hen van alles verwittigen wat in de factorij van zoodanige Europeesche natie als zij bedienen voorvalt. En gelijk een ieder gaarne de schuld van zich afschuift, zoo excuseeren zich de fiadors ook doorgaans bij de mandarijns, dat de tolken en compradors hun plichten niet nakomen, de Europeanen opzetten dan wel kwade denkbeelden bijbrengen, weswegens de mandarijns als voor een regel hebben genomen in de meeste gevallen eerst de tolken en compradors, als meest of naast bij de Europeanen zijnde, aan te tasten, waardoor teffens de fiadors, dat vrij aanzienlijker luiden en hun beter de handen smeren kunnen, sparen terwijl de soldaten of lage dienaars van de justitie de tolken en compradors in alle voorkomende gelegenheden zooveel afpersen als doenlijk is. ${ }^{3}$

1 Dagregister der Cantonsche bediendens 6 Mei 1763.

3 Het Portugeesche woord comprador d.i. kooper. Over hun taak zie beneden.

3 Dagregister als voren. In het rapport door de Cantonsche bediendens op 4 Januari 1765 aan de Hooge Regeering te Batavia overgezonden, wordt gezegd dat, ofsehoon een fiador volgens de letter van zijn verbandschrift aan de mandarijnen zich aan lijf- en levensstraf blootstelde wegens misdrijven, door een Europeaan van het schip dat hij als borg had gesecureerd gepleegd, er echter van den kant der mandarijnen veel inschikke. lijkheid in dezen werd gebruikt. 
Tot de taak van de compradors behoorde het om voor de Europeanen, die hen in dienst hadden genomen, den leeftocht en alle andere dagelijksche behoeften in te koopen ${ }^{1}$ alsook het proviand, dat de schepen voor de thuisreis noodig hadden. ${ }^{2}$ Gewoonlijk bezorgden zij ook de werklieden voor den arbeid, die er in de factorij te verrichten viel. ${ }^{3}$ Alle andere Chineezen die daarbinnen of daarbuiten eenigerlei dienst verrichtten: koelies, handwerkslieden, winkeliers, om het even wie, stonden onder hun onmiddellijk bevel. Wederkeerig stelden de compradors zich borg voor het gedrag en de goede trouw van het onder hen werkend volk. ${ }^{4}$ Eindelijk, om van hun minder beduidende beroepsplichten te zwijgen, ${ }^{5}$ was hun de zorg toebetrouwd voor de tresorie, waarin de contanten en andere dingen van waarde waren opgeborgen. ${ }^{6}$ Het aantal compradors, dat de onzen in dienst hadden bedroeg twee, ${ }^{7}$ waarvan de eene denkelijk de inkoopen voor de factorij en de andere die voor het schip zal heoben gedaan. ${ }^{8}$

Het verblijf, waarin de carga's gedurende den ganschen tijd dien zij te Canton doorbrachten waren gevestigd, was een gewoon

1 Lockyer, a. w. blz. 58; Osbeck, a. w. S. 58; Ekeberg, a. w. S. 78.

${ }^{2}$ Ekeberg t.a.p.

3 Ekeberg t. a. p.; Fan-Kwae or Canton before treaty days (1825-1844), London 1882 , p. 53. Ook de cassarekening der carga's heeft klaarblijkelijk zulke diensten op het oog als zij onder de uitgaven voor de „oprichting der factorij" een post vermeldt van "per zooveel in differente reizen aan de compradores Tham en Jacque" betaald en toegewogen.

4 Fan-Kwae, p. 53. De volgende bijzonderheden omtrent de compradors zijn, tenzij een andere bron is vermeld, ontleend aan dit werk, dat onder den titel Fan-Kwae de herinneringen bevat van een oud-ambtenaar der Engelsche Compagnie tijdens zijn verblijf te Canton van 1825-1844. De toestanden weken toen in het uiterst conservatieve China weinig of niet af van die van een eeuw vroeger, wat trouwens bij vergelijking van zijn berichten met die van de Hollandsche carga's van 1729 herhaaldelijk aan het licht komt. Volgens Wells Williams, The Chinese commercial guide p. 161 moesten de compradors (mai-pan) een permissie hebben van de overheid, stonden zij gewoonlijk in connectie met de Chineesche koopmans- en bankierszaken en dienden zij tevens als dwarskijkers en spionnen voor alles wat in de factorij gebeurde.

${ }^{5}$ Volgens Osbeck, a. w. S. 149 moest een van de compradors een ieder, die zich naar boord begaf, tot aan het naaste tjap. of tolhuis begeleiden om daar aan te geven wie hij was en wat hij van Canton medebracht; en werden ook de begrafenissen van de in China overleden Europeanen door hen bezorgd.

6 Fan-Kwae, p. 54.

7 Blijkens de cassarekening der carga's.

${ }^{8}$ Zoo was het tenminste in het tijdperk 1825-1844, zie Fan-Kwae, p. 53 en 102. 
Chineesch koopmanshuis, dat uit- en inwendig geheel het evenbeeld zal hebben vertoond van de Europeesche factorijen gelijk deze beschreven worden door achttiende-eeuwsche reizigers, die ze met eigen oogen hadden aanschouwd. $Z$ ij stonden in de voorstad langs de rivier, boven welke zij somtijds op palen waren uitgebouwd. Zij waren opgetrokken van gebakken of in de zon gedroogde ${ }^{1}$ klinkersteen en met pannen of ook wel met houten singelplankjes gedekt, ${ }^{2}$ bezaten slechts twee verdiepingen, liepen diep in en kwamen met de achterzijde uit aan de zoogenaamde factorijstraat. De afscheidingen tusschen de verschillende vertrekken bestonden in houten beschotten, waartegen bij wijze van behangsel dun, wit Chineesch papier was opgeplakt. Het hieruit voortspruitende brandgevaar, bij de gebrekkige bluschmiddelen daar te lande op zichzelf reeds groot genoeg, ${ }^{3}$ werd nog verergerd doordien de zolders en gedeeltelijk ook de trappen insgelijks van hout waren vervaardigd. De vloer van de benedenverdieping was evenals de binnenplaats met steenen geplaveid. De hooge kamers ontvingen nagenoeg altijd maar van één kant licht door lange, smalle vensters met vierkante in hout gevatte ruiten van een soort van parelmoer of van schelpen (glasruiten in lood gezet zag men in geen enkel Chineesch huis), die nog minder licht doorlieten dan het hoorn gelijk men dat voor lantarens bezigde. Bij zomerdag echter, zoo verhaalt een van onze zegslieden, waren "hare vensters van rotting of geheel opengelaten met gordijnen van bamboe, jalousieën om zoo te spreken, "als een roosterwerk getralied om neer te kunnen laten als men wilde. 4 In elk vertrek hing

1 Dit moet m.i. de "rauwe" klinkersteen zijn geweest welke de Chineezen volgens Lockyer (a. w. blz. 94) bij het bouwen van hunne huizen bezigden. Osbeck (a. w. S. 174) zegt, dat sommige factorijen waren naufgeführt von ungebrannten Ziegelsteinen."

2 Osbeck a. w., S. 174:

3 Niet te vergeten ook het gedrag van de bevolking in zulke gevallen; het is overbekend, zoo schreven de Cantonsche bediendens op 15 Febr. 1773 aan den Advocaat der Compagnie, hoe lafhartig zich de Chineezen bij voorvallende branden houden, zij laten huis en hof staan, bergen zooveel zij kunnen en offeren het overige aan de vlammen op.

4 Volgens Ekeberg, Ostindische Reise in den Jahren 1770-1771, Dresden, Leipzig 1785 , S. 89 hadden de Chineesche eigenaars toen kort geleden aan de Europeanen toegestaan hun woningen naar den Europeeschen smaak in te richten, ze van glasvensters in plaats van met donkere parelmoervensters te voorzien, de houten afscheidingen tusschen de vertrekken door steenen muren te vervangen en in plaats van de met papier overplakte matten gips. vloeren aan te leggen. 
een met een lange lijn aan den zolder bevestigde lamp. Aan weerszijden van den binnenhof werden de opslagplaatsen aangetroffen voor de thee, de porcelein en de andere ingekochte koopmanschappen. Op de bovenverdieping bevonden zich een paar zalen, van welke de eene veelal als eetzaal werd gebruikt, en daaronder de keuken en de waschkamer voor de ingekwartierde matrozenwacht, waarvan er gestadig eenigen met ontbloote degens voor de factorij op post stonden om alle onwelkome bezoekers den toegang te beletten, terwijl anderen telkens als er een afscheping van goederen plaats had gewapend medegingen op de champans ten einde een oog in het zeil te houden, dat de gezagvoerder van de schuit zich niet het een of ander van de ingeladen waar toeëigende. Voorts bezaten alle factorijen-een overwelfd vertrek ter bewaring van de contanten, benevens een gong, waarop de tijd werd aangegeven en het oogenblik, dat het middag- en avondmaal zou worden opgeschaft. ${ }^{1}$ Naar den kant van de rivier was een vlaggestok opgesteld, van welken bij alle plechtige gelegenheden de nationale kleuren der bewoners wapperden. ${ }^{2}$

Onder het huisraad, naar Europeeschen trant grootendeels bestaande in ledikanten, tafels, stoelen, banken, tafel-, keukenen ander gerei, trok in de Hollandsche factorij van 1729 in het bijzonder het betrekkelijk groot aantal weegschalen de aandacht, ${ }^{3}$ een gereedschap bij de negotie in China nog veel onmisbaarder dan in Europa, wijl de Chineezen schier alles, tot hout en water toe, bij het gewicht verhandelden. ${ }^{4}$ Gezegend de carga's, die het geluk hadden over een eerlijken comprador te beschikken, ${ }^{5}$ of zelf fluksch en snedig genoeg waren om de

1 In verband met dit alles verdienen opmerking de door de carga's onder het hoofd "factorijsinrichting en dispensonkosten" verantwoorde uitgaven voor: 2 bekkens om het uur op te slaan, 3 jalousiematten, 4 groote hanglantarens, 1 katoenen lijn voor de lantaren, 17 boek papier om te plakken, 6 bamboeze matten, pannen voor het dak, vloersteenen.

${ }^{2}$ Lockyer, a. w., blz. 94; Osbeck, a. w., S. 173 flg.; Ekeberg, a. w. S. 89; Sonnerat, a. w. II blz. 193.

3. De rekening der carga's vermeldt onder het hoofd „factorijsoprichting en dispensonkosten", behalve voor de genoemde meubelen en het andere gerei, ook uitgaven wegens een galg voor de schaal, een galg voor de kleine schaal en een "groote daetsie."

4 Toreen, a. w., S. 501.

5 Lockyer (a. w., blz. 58) sohrijft dat in zijn tijd, omstreeks 1711 , de Chineesche compradors onlangs waren afgedankt, omdat de hoppo's hen met geld tot zulke "boeven" hadden gemaakt. 
sluwe streken van de landzaten te doorzien, want zoo wij geloof mogen slaan aan hetgeen door een Engelschen zeeman uit de eerste helft der $18^{\text {de }}$ eeuw wordt verzekerd, waren de C'hineezen meesters in de kunst om van de gewoonte, om alles bij het gewicht te verhandelen, op de meest geraffineerde wijze partij te trekken. Eens, verhaalt hij, toen men voor zijn schip eenden en ander gevogelte had ingekocht, kwamen die meest alle terstond te sterven. In het eerst vermoedde het scheepsvolk dat zij vergeven waren tot bij nader onderzoek aan het licht kwam dat zij, om ze zwaarder te doen wegen, met steentjes en zand waren volgepropt, sommige zelfs met niet minder dan tien Engelsche onsen. ${ }^{1}$ Aan de varkens (vertelt hij al verder), die geslacht aan boord werden geleverd, was water ingespoten, zoodat een dat men een nacht had laten hangen om het water er uit te doen loopen meer dan acht pond ${ }^{2}$ van zijn gewicht verloor, en toen men om tegen zulk bedrog gedekt te wezen de varkens levend aanschafte, kwam men tot de ontdekking dat de Chineezen hun zout ingaven om den dorst op te wekken en, als zij hun door dat middel water in het lijf hadden gekregen, naarstig zorg droegen dat de dieren dit niet weer natuurlijk konden kwijt raken. ${ }^{3}$

Van de weegschalen in de factorij diende de "groote daetsie" voor het wegen van thee- en porceleinkassen, in het algemeen voor alle zware goederen wier gewicht bij pikols en katti's werd berekend. ${ }^{4}$ De kleinere datjings, ${ }^{5}$ om ze met hun onverbasterde Chineesche benaming te noemen, werden gebezigd voor lichte waren alsook wanneer er een betaling in zilver geschiedde. In China toch, gelijk men weet, bestond maar één enkele soort van munt, de welbekende kassi's, kleine ronde stukjes van messing gegoten, ${ }^{6}$ die in het midden een vierkant gaatje

1 Een Engelsche ounce $=0.02835$ kilogram.

2 Een Engelsch pound $=0.45359$ kilogram.

3 G. Anson, Reize rondsom de wereld (1740-1744), Amst. 1748, blz. 368.

4 Osbeck, a. w., S. 216. Een pikol = 100 katti's.

${ }^{5}$ Datjing of unster, de afkomst van het woord is onzeker, zie HobsonJobson i.v. datchin.

6 Toreen, a.w., S. 502; Osbeck, a. w., S. 216. De samenstelling bestond volgens de Historische beschrijping der reizen, 's Grav.-Amst. 1747-1767, IX blz. 108, in 6 deelen koper en 4 deelen lood, hetzelfde gehalte wordt ook opgegeven in de Description of the city of Canton, Canton 1839, p. 126. Daar de kassi's echter niet geslagen maar gegoten werden en dus zeer gemakkelijk waren na te maken, werden zij door alle eeuwen heen op uitgebreide schaal vervalseht, vgl. W. Vissering, On chinese currency, Leyden 1877, Introductory chapter, p. 11. 
bezaten, zoodat men ze met een doorgestoken touw tot risten kon aaneensnoeren ${ }^{1}$ - de taels, mazen en condorijns, waarin de Chineezen de hoogere prijzen uitdrukten, waren uitsluitend rekenmunten, werkelijke geldstukken van dien naam bestonden niet. ${ }^{2}$ Wie een schuld te betalen had, te groot om ze te kwijten met de louter voor pasmunt bestemde kassi's, voldeed die hetzij in zilverklompen, naar hun vorm meestal schuitjes of schoenen geheeten, ${ }^{3}$ hetzij in van buitenslands aangevoerde zilveren muntspeciën. De laatste werden dan even goed als de schuitjes door de Chineezen geheel behandeld als gewone koopwaar. Meesters als zij waren in de kunst om zelfs op het bloote gezicht den graad van de meerdere of mindere fijnheid van het zilver te onderscheiden, ${ }^{4}$ stelden zij het ware zilvergehalte van de speciën vast, wogen ze op een kleine balans, die ze altoos in een verlakt doosje aan den gordel bij zich droegen, ${ }^{5}$ en bepaalden vervolgens, precies als bij gewone koopmanschappen, de waarde voor welke zij de speciën aanvaardden. ${ }^{6}$ Wilden zij in zilver een kleine betaling doen, zoo namen zij eenvoudig een Mexikaanschen daalder of welk ander vreemd zilverstuk zij toevallig bij de hand hadden tusschen de bladen van de geldschaar, die zij evenals de unster gestadig $\mathrm{bij}_{\mathrm{ij}}$ ich droegen, en klopten er zoo lang mede op een steen tot er een brokje afviel juist groot genoeg om als pasmunt te kunnen dienen. ${ }^{7}$ Dat men om bij zulk werk niet om den tuin te worden geleid op het nauwlettendst had toe te zien, is duidelijk. Weeg, aldus een Engelschman uit het begin van de $18^{\mathrm{e}}$ eeuw die den handel te Canton kende, weeg uw zilver nimmer af met de datchin van een Chinees, want die bezit er gemeenlijk twee, een voor het ontvangen en een voor het betalen, en die met het werktuigje goed weet om te

1 Hist. beschrijving der reizen t. a.p.; A. Meijer, Dagboek gehouden gedurende een reis naar China in 1827 in Tijdschr. voor Nederl. Indië 3e Jaarg. (1840) blz. 206.

2 Een tael $=10$ maas, een maas $=10$ condorijn, een condorijn $=10$ kassi's.

${ }^{3}$ Afbeelding van Chineesche en Japansche zilveren schuitjes in de Hist. beschrijv. der reizen XVI blz. 344 .

4 Hist. beschrijv. der reizen IX blz. 107.

${ }^{5}$ Als voren; Lockyer, a. w., blz. 78; A. Meijer, Dagboek, t. a. p.; FanKwae, p. 58.

6 Fan-Kwae p. 56.

7 Lockyer, a.w., blz. 78; Osbeck, a.w., S. 216; Hist. beschrịjving der reizen XVI blz. 344 ; A. Meijer, J)agboek, t. a. p. 
gaan kan door plaatsing van het gewicht of een anderen kunstgreep zijn partij wel voor twee of drie ten honderd benadeelen. ${ }^{1}$ Mocht een Europeaan, die bij slot van rekening toch ook mensch was, soms in de verzoeking komen list tegenover list te stellen, hij werd al spoedig gewaar dat de Chinees, loos als hij was in het bedriegen, niet minder handig de streken wist te verijdelen, daar men hem zelf mede zocht te verkloeken. ${ }^{2}$

De boekhouding in de factorij, welke naar Chineeschen trant geheel geschiedde in taels, mazen, condorijns en cassies-de tael aan ongeveer f 3.55 gerekend, ${ }^{3}$ - behoorde tot de bijzondere ambtstaak van den tweeden en derden carga. De tweede carga teekende de uitgaven aan voor de "factorijsoprichting» en de "dispensonkosten, dat wil zeggen de kosten voor het aanschaffen van keuken- en andere huishoudelijke behoeften, hield verder de cassarekening en boekte de afpakkingen van de ingekochte koopwaren. Het leeuwendeel evenwel van het kantoorwerk werd door den derden of "jongsten» carga afgedaan. Behalve het negotieboek en een dubbel van de afpakboeken, hield hij nog het register bij van de besluiten, door de carga's op het stuk van den handel genomen, en schreef bovendien in het zoogenaamde dagregister alles op wat er dag aan dag voor belangrijks in de factorij voorviel.

Aan het eigenlijke negotiebedrijf daarentegen werd door al de carga's gelijkelijk deelgenomen. Waren er besluiten te nemen omtrent het inkoopen van deze of gene waar, moest men in de winkels zijn gading zoeken, vielen er goederen in gereedheid te brengen voor de afscheping naar boord, steeds pleegden zij met elkander overleg, liepen met hun drieën de magazijnen der Chineesche kooplieden af, en hielden in de

1 Lockyer, a. w., blz. 62.

2 Hist. beschrijving der reizen, XVI blz. 344 .

s Blijkens de boeken zelf. In een notitie omstreeks dezen zelfden tijd aangeboden aan den Zeeuwschen Bewindhebber Samuel Radermacher, klaarblijkkelijk door iemand die gebruik maakte van inlichtingen hem door bedienden van de Ostendische compagnie verstrekt, werd een tael "gerekend circa f 3.50 Hollandsch" (Papieren Radermacher, Kol. Aanw. 112). De benamingen tael maas, condorijn en kassi zijn niet van Chineesehen oorsprong, de drie eerste wil men dat door bemiddeling van het Maleisch uit Indië zouden zijn overgebracht, kassi wordt afgeleid van caixa, den naam eener door de Portugeezen in 1511 te Malakka aangetroffen munt, F. Hirth, Chinesische Studien, S. 215. 
pakhuizen van hun leveranciers gezamenlijk toezicht op het «tarren» en pakken van de thee- en porceleinkassen. ${ }^{1}$ Hoeveel er met dat alles, inzonderheid met het pakken, van hun tijd werd gevergd, kan het door hen gehouden dagregister getuigen: voor het drukste gedeelte van het seizoen hangt het bij manier van spreken van pakken en nogmaals pakken aaneen. Niet te verwonderen trouwens, wanneer men bedenkt dat er alleen met thee, ongerekend hetgeen in kanassers en kleinere fustage ging, ${ }^{2}$ over de 930 kassen moesten gevuld worden en dat met het pakken van een honderdtal kassen, de gewone grootte van een afgeleverde partij, een gansche dag was gemoeid, ${ }^{3}-$ om te zwijgen van de porcelein, waarvan er een 137 kassen waren in te pakken en die uit den aard der zaak nog veel meer tijd vorderde dan de thee. ${ }^{*}$

Een afwisseling in den dagelijkschen sleurgang van dit bestaan boden de dagen, dat de carga's de Chineesche kooplieden als gasten aan hun disch hadden of zelve bij hen te waardschap gingen. ${ }^{5} \mathrm{Nu}$ en dan ook kwam een neef van den hoppo ten hunnent op bezoek om naar hun welstand te vernemen en te verzekeren, wat "bijzondere affectie" hij gevoelde voor de Hollanders, bij welke gelegenheden hij dan na recht gemoedelijk «een pijpje gerookt en al ettelijke glaasjes wijn gedronken " te hebben «met zeer veel contentement» weder huiswaarts keerde. Soms verraste hij de Hollanders bij zijn komst met een geschenk van Chineesche oranjeappelen, "tot bewijs zijner achting» gelijk hij zeide, of liet aan de factorij "een klein koebeestje en een pikol meel bezorgen met verzoek dat de onzen "hetzelve op zijn gezondheid geliefden te verorberen." ${ }^{6}$ Tot zelfs de hoppo toe kwam hun met zijn beleefdheden te gemoet. Reeds in de eerste maand van hun verblijf, op het einde van Augustus,

1 Resolutieregister en Dagregister passim.

${ }^{2}$ De hoeveelheid thee, die in kanassers en kleine kasjes werd gepakt bedroeg 25262 katti's, bijna een tiende van de gansche theelading, Brief van de carga's aan de Kamer Amsterdam 3 April 1730.

3 Dagregister 28 Oct., 1, 13 en 24 Nov. 1729.

- Met porcelein pakken hield men zich blijkens de pakboeken onledig op $3,5,6,9,12,14-16$ en 19 Sept., $1,4-6,18,23,27$ en 30 Oet. en 9 Nov. 1729, met theepakken op 28 Oct., 1, 5, 11-16, 24 en 27 Nov.. 3, 4, 6, 7, 9 en 18 Dec. 1729.

5 Dagregister 14, 15, 23 en 28 Aug., 23, 29 en 30 Dec. 1729.

6 Dagregister 17 en 24 Sept., 16 Oet, en 26 Nov. 1729. 
kwamen diens "twee eerste huisverzorgers» of pay de cases bij de carga's hun opwachting maken om uit hun meesters naam naar hun gezondheid te informeeren en tegelijkertijd mede te deelen, dat deze voornemens was om, zoodra hij den zwaren rouw over zijn onlangs overleden broeder had afgelegd, "alsdan een comedie, bij haar luiden wajang genoemd, ter eere van de Hollanders vóór derzelver factorij te laten oprichten.» Liefst, zegt het dagregister, hadden wij de eer afgewezen maar bedenkende dat een weigering van onzen kant den hoppo "ongetwijfeld niet zeer aangenaam? zou wezen, lieten wij er ons genoegen over betuigen ${ }^{1} \mathrm{Na}$ verloop van een dag of tien liet de hooge mandarijn weten dat hij des anderen daags met de wajangvoorstelling meende door te gaan, en zond bijna onmiddellijk daarop al vooraf den noodigen toestel tot "de uitvoering van die aperijen," zooals de nuchtere schrijver van het dagregister het uitdrukt. ${ }^{2}$ Den volgenden dag deed hij niet alleen de voor het spel vereischte "ornamenten» aanbrengen, "maar daar benevens zeer velerlei spijzen en vruchten om de genoodigde gasten, die meerendeels bestonden uit de aanzienlijkste kooplieden van deze plaats, wel te onthalen en goede ciere aan te doen. En om dit gezelschap luister bij te zetten zoo stuurde hij in zijnen name deszelfs zusters zoon, zijnen eersten bediende. Ook liet hij de stoelen en de tafels, daar men zoude op- en aanzitten, altemaal behangen met fraaie roode satijnen kleeden, rijkelijk met goud geborduurd, een pracht (voegt onze schrijver er bij) die niet als onder zeer aanzienlijke Chineezen gebruikelijk is.) Met het begin van het spel, dat van 's avonds acht uur tot na middernacht duurde, vervoegde zich het gezelschap aan de tafels "alwaar van tijd tot tijd zeer vele gerechten wierden opgebracht; ondertusschen (zoo merkt de schrijver van het dagregister $o p$ ) verzuimden sommige Chineesche kooplieden en andere genoodigde gasten niet al een stout glas wijn zoowel roode, witte als Fransche te drinken, inzonderheid ook 's hoppo's neef, die zich nevens vele anderen zeer vroolijk aanstelde, gelijk zij ook allen na het eindigen van de wajang wonderwel voldaan hun weegs gingen. ${ }^{3}$ Geen twijfel of de vertooning heeft de Hollandsche gasten veel verknepen gegeeuw gekost,

1 Dagregister 27 Aug. 1729.

2 Dagregister 6 Sept. 1729.

s Dagregister 7 Sept. 1729. 
doch natuurlijk waren zij wijs genoeg om den wenk van een hunner Chineesche vrienden op te volgen, die hun aanraadde de "twintig acteurs en verdere bijhebbende bedelaars» met een flinke fooi te beschenken, opdat men zien mocht hoe hoog zij de hun door den hoppo bewezen eer waardeerden. ${ }^{1}$ De toeleg om de Chineesche ambtenaarswereld gunstig voor zich te stemmen, spreekt eveneens uit de wijze, waarop zij met de mandarijnen van het hoppo's- of douanekantoor omgingen. Zoo dikwijls dezen zich aan de factorij vervoegden voor het visiteeren van de aldaar aangebrachte of voor afscheep gereed staande goederen, droegen de onzen zorg dat "die schrokdarmen, gelijk het dagregister de heeren vrij oneerbiedig betitelt, niet heen gingen dan na hunne ingewanden eerst braaf met spijze en vaderlandsche dranken van wijnen en bier» te hebben "volgepropt, zoodat zij altoos "welvergenoegd" ja een enkele maal als ietwat "geraakt door den drank, zeer vroolijk» te moede, van hun Hollandsche gastheeren afscheid namen. ${ }^{2}$

Vijfdehalve maand ongeveer hadden de carga's op den hier geschetsten voet in de factorij te Canton gewerkt en geleefd, toen zij met hun laatsten inkoop op 26 December 1729 de hun opgedragen taak in China afweefden. De volgende dagen werden geheel besteed aan de toebereidselen voor de afreis. $\mathrm{Zij}$ ontruimden de factorij, zonden het scheepsvolk dat er den wachtdienst had gedaan met de laatst ingekochte koopmanschappen en den overgeschoten leeftocht naar boord, legden bij de voornaamste Chineesche negotianten afscheidsbezoeken af, voorzagen zich van het "groote tjap» zonder hetwelk men niet uit China wegzeilen mocht, ${ }^{3}$ en lieten de meubelen uit de factorij ter bewaring voor de na hen komende carga's overbrengen naar de woning van den koopman Tanhonqua, bij wien $\mathrm{zij}$ sinds het verlaten van de factorij weder hun intrek hadden genomen. ${ }^{+}$Op Nieuwjaarsdag 1730 was alles voor het vertrek in gereedheid. $\mathrm{Na}$ de schrijvers, bedienden en koelies van de gezamenlijke kooplieden, met wie zij handel hadden

1 Cassarekening (hoofdstuk presenten) 7 Sept. 1729: aan de „20 acteurs enz." een geschenk gegeven van 40 tael (= omtrent 140 à 142 gulden).

2 Dagregister 1 Sept., 15 Oct., 8, 18, 22 en 29 Nov. en 24 Dec. 1729.

s Vgl. Fan-Kwae p. 103; Dagregister der bedienden te Canton 21 Nov. 1772 en resolutie van dezen 11 Dec. 1773.

4 Dagregister 27, 28, 30 en 31.Dec. 1729.

Dl. 73 
gedreven, op hun gebedel met een fooitje te hebben bedacht, een "oud hoewel slecht gebruik, zeggen zij, doch "hetgeen men, zoo men ons onderrichtte, niet wel zonder zich aan affronten te exponeeren voorbij kon, ${ }^{1}$ stapten de carga's des namiddags met Tanhonqua en nog eenige van zijn confraters op een deftigheidshalve door hem gehuurde mandarijnschampan, ${ }^{2}$ tot aan boord begeleid door verscheidene aanzienlijke kooplieden, zoo Engelsche, Portugeesche, Armenische als Chineeesche. Laat in den avond bij het schip aankomende, bleven de passagiers allen op de champan overnachten om den volgenden ochtend, met wederzijdsche dankbetuigingen voor al het goede over en weer genoten, van elkander afscheid te nemen. Straks daarop voer het Chineesche gezelschap naar Canton terug $;{ }^{3}$ en eer het jaar een week ouder was wiegelde de Coxhorn op het ruime sop, den steven gewend naar het lieve Vaderland. ${ }^{*}$

Een kostbaar, rijk retour was het, dat zij hier te lande aanbracht deze kiel, toen zij den 13 Juli 1730 ter reede van Tessel het anker liet vallen ${ }^{5}$ : niet minder dan 268479 pond thee, ${ }^{6}$ voorts 570 stuks zijdestoffen van allerlei kleuren en tinten, ${ }^{7}$ en ten slotte een schat van porcelein om de lief hebbers

1 Dagregister en resol. der earga's 1 Januari 1730. Het cumsha- of fooienstelsel bloeide te Canton volop, zoo het schịnt; behalve de $26 \frac{1}{2}$ tael (92 à 94 gulden omtrent) aan de schrijvers c.s. geschonken, gaven de carga's blijkens de eassarekening nog $26 \%$, Tael aan de bedienden van den neef van den hoppo, die hen persoonlijk uitgeleide deed, de bemanning van de champan waarmede Tanhonqua hen aan boord had gebracht, zijn dienstpersoneel tot koks incluis en anderen.

2 Volgens Osbeck, a. w. S. 166, een roodgeverfde boot, versierd met geschilderde draken en andere figuren en met kleine vlaggen.

3 Dagregister 1 Januari 1730.

4 Blijkens den brief der earga's aan de Kamer Amsterdam van 3 April 1730 stak het schip van vóór Macao in zee op 7 Januari 1730.

${ }^{5}$ Brief van dezelfden aan dezelfde Kamer 13 Juli 1730.

6 Zoo wordt de hoeveelheid opgegeven in de "Consideratiën omtrent eenige artikelen rakende den handel op China," door Thomas Hope in 1751 aangeboden aan den Opperbewindhebber Prins Willem V (Papieren Hope, Kol. Arch. 8471). De brief van de earga's aan de Kamer Amsterdam van 3 April 1730 geeft op dat de theelading was samengesteld uit 226827 katti's boei, 14915 kattis congo en 10347 kattis heysan.

7 Blijkens het pakboek van het schip waren in de zijdekassen gepakt 242 gebloemde achtdraads damasten of zoogenaamde poysjes van de volgende kleuren: licht-, donker- en hemelsblauw, muskuskleur, paille- of strookleur, rood, rozerood, bruin, geel, geel- en wit, groen, loodkleur, wit, blauw- en wit, zwart, jonquille, ponceau, aschgrauw en incarnaat; 88 achtdraads gorgorons-zwart, donkerblauw, hemelsblauw, bruin, geel, aschgrauw, purper, groen, rood, wit, olijfkleur -; en 240 zesdraads pekins- geel, paille, ponceau, wit, bruin, groen, bleu morant, donkerblauw, rozerood, aschgrauw en zwart. 
te doen watertanden, te weten 124595 paar thee-, 17040 paar koffie- en 9457 paar chocolaadgoed, 490 thee- en 116 tafelserviezen, 49 serviezen "nappen" of holle schotels, 260 nesten kommen, 100 nesten schotels en kommen, 105 nesten nappen of holle schotels, 20280 borden, 810 trekpotten, 251 paar gedekte suikerbusjes, 600 patipans, 600 schuitjes, 10255 paar borden en kommen, 10145 borden, ${ }^{1}$ - alles te zamen een inkoopswaarde vertegenwoordigend van 273960 à 277874 gulden. ${ }^{2}$ Bij den afloop van de veilingen bleek de tocht van de Coxhorn na aftrek van alle onkosten en lasten een zuivere winst te hebben opgeleverd van bijna $3 \frac{1}{4}$ ton goud. ${ }^{3}$

Moest deze gunstige uitslag voor de Bewindhebbers een spoorslag zijn om den Chinaschen handel op denzelfden voet voort te zetten, de onderneming had dit als schaduwzijde dat zij de goede betrekkingen met de Engelsche zustercompagnie dreigde te verstoren, welke de onzen in den strijd tegen de Ostendenaars zoo wel te stade waren gekomen en bij de allerwege opstekende concurrentie nog steeds van het grootste belang bleven. In het eerst namelijk meende men op het Indische Huis te Londen, ook op grond van brieven uit Holland zelve ontvangen, zoo schreef in December 1731 een van de Engelsche directeuren, de bekende Sir Matthew Decker, aan den Eersten advocaat der Nederlandsche Compagnie Abraham Westerveen, dat "deze nieuwe entreprise geen ander uitzicht had als tot nadeel van deze ${ }^{4}$ Compagnie en om dezelve, zoo veel als in de macht van UEd. Compagnie was, afbreuk te doen, en heeft waarlijk veel kwaad bloed gezet te meer omdat het geschrevene van Holland volkomen geloofd wierd; en dat daartoe hielp

1 Volgens de opgaven in het Specificatie- en Grootboekje van het door de carga's genegotieerde te Canton. Bij het theegoed waren 13805 paar bruin en blauw, bij het chocolaadgoed 2550 paar wit, bij de theeserviezen 324 geëmaljeerd en 176 wit, bij de 260 nesten kommen 140 gekleurd, het overige was alles blauw en wit. Van de tafelserviezen bestonden 56 elk in 13 schotels, de 60 overige ieder in 19 schotels en 30 borden; de serviezen nappen telden ieder 21 schotels, de nesten nappen ieder 5 schotels, de nesten schotels en kommen ieder 8 schotels en 8 kommen, dé nesten kommen ieder 5 stuks.

2 Blijkens het Grootboekje van de carga's was er voor den inkoop van de thee, de zijdestoffen en de porcelein besteed resp. 233104 a 236434,11466 it 11630,29388 à 29808 gulden (de tael gerekend aan $f 3.50$ à f 3.55 ).

3 De hiervóór aangehaalde Consideratiën van Thomas Hope noemen een som van 324471 gulden 19 stuiver 8 penningen.

4 D. i. de Engelsehe. 
was, dat het zoo direct strijdig is tegen het reeële interest van UEd. Compagnie, gelijk vele van onze directeuren en alle andere bedienden die in China geweest zijn eenparig zeiden. En hoever dit ging (vervolgt Sir Matthew) zal ik UEd. een staaltje van aanhalen, waarbij UEd. de rest kunt oordeelen: toen eerst deze tijding kwam en dat er bij gevoegd werd, dat het alleen geschiedde om onze Compagnie te benadeelen, zoo was onze vergadering zeer heet. Als gemeenlijk in zulke warmtens wel dingen worden geproponeerd, die men bij nadere consideratie wel anders aanziet, zoo waren er wel eenige op het tapijt die juist niet aangenaam kunnen zijn dat men die zelfs noemt, doch de gemodereerdsten waren van gedachten dat men hier een representatie over aan onzen Secretaris van Staat behoorde te doen, niet om het recht van UEd. Compagnie om op China te mogen handelen te disputeeren maar alleenlijk om aan te toonen de hardigheid van de zaak, dat de keizer principaal door de macht van onzen koning gebracht was om te consenteeren dat er in geen zeven jaren schepen van Ostende naar Indië zouden gaan, ${ }^{1}$ en dat nu dezelve intentie tot nadeel aan ons wierd toegebracht door UEd. Compagnie, die in zooveel jaren niet direct naar China hadde gevaren.» Gelukkig werd de vrees voor de nadeelen, welke de Engelschen van onze verschijning in China verwacht hadden, door de uitkomst al spoedig gelogenstraft. "UEd. of andere heeren (zoo schrijft Decker in dienzelfden brief) zullen licht denken dat ik mij hier zoo ampel over uitlaat omdat dit een groot nadeel aan ons is; gansch niet, al wat wij er van apprehendeerden in het begin was dat het de thee in China considerabel zou doen rijzen en dat was zekerlijk schade voor ons, doch dit is niet gebeurd en wij hebben onze thee zoo goedkoop sedert als van te voren gehad. En wat de quantiteit aangaat, of UEd. die direct uit China of over Batavia in Europa brengt is ons hetzelfde, en dat er quantiteit in overvloed is zijn wij ook overtuigd, want nu de Chineezen zien dat men zoo groote eischen voor thee doet, zijn zij verstandig genoeg om die door culture en aanplanting te vermeerderen. Vóór 25 of 30 jaar was het contrarie, toen kost gansch China niet boven 5 à 6000 pikols 's jaars leveren, gelijk mij nog onlangs een van onze oude supercarga's heeft

1 Bij het verdrag van Parijs van 31 Mei 1727, zie hiervóór blz. 58. 
gezegd. $\mathrm{Nu}$ zij van onze concurrentie te Canton geen nadeel meer behoefte te duchten, bestond er voor de Engelsche Compagnie dus ook geen reden meer om in minder goede verstandhouding te leven met de Hollandsche, integendeel zij wenschte die, gelijk Decker aan het slot van zijn brief verklaarde, veeleer aan te kweeken, overtuigd als zij was dat de tegenwoordige tijdsomstandigheden haar meer dan ooit vereischten. ${ }^{1}$

Mag men geloof slaan aan het geen van zekere zijde tegen hen werd ingebracht, dan ware, als de carga's beter hun plicht hadden betracht, de onderneming voor de Compagnie nog aanmerkelijk winstgevender geweest. $\mathrm{Zij}$ zouden namelijk niets meer of minder hebben gedaan dan hunne meesters bedriegen en bestelen. Naar luid van een brief, op 1 September 1730 uit Londen afgezonden aan een ongenoemde, die hem op zijn beurt weder ter kennis bracht zoo het schijnt van den Raadpensionaris van Slingelandt, vertelde men daar ter stede openlijk dat de carga's de door hen ingeslagen thee en andere koopwaren voor omtrent 20 procent hooger hadden aangerekend dan de prijzen, daar zij in Canton voor waren ingekocht. Toen de schrijver van dien brief zich persoonlijk bij Sir Matthew Decker, den toenmaligen president der Engelsche Oost-Indische Compagnie, van de toedracht der zaak ging vergewissen, deelde deze hem mede dat een van de onlangs uit China teruggekeerde Engelsche carga's hem was komen vertellen, hoe niet alleen zijn eigen confraters maar ook de Hollandsche carga's van de Coxhorn de thee, die tegen 19 à 20 tael door hen was ingekocht, in hun boeken voor 24 tot 26 tael in rekening hadden gebracht en, zeide hij, met alle andere koopmanschappen hebben zij naar rato gehandeld. Tot staving van zijn beweren had hij aan Decker een brief overhandigd met bijbehoorende verklaring en rekening van twee van de eerlijkste kooplieden te Canton, waarbij zij de Engelsche Compagnie van dit schelmstuk verwittigden, en, zoo had hij er bij gezegd, ik heb een brief medegebracht van diezelfde kooplieden aan de Hollandsche Compagnie, die haar carga's van hetzelfde beticht en eenige weken geleden door mij bezorgd is aan den hier te Londen gevestigden agent van de Hollandsche Compagnie. Als bewijs had hij er nog aan toegevoegd dat hij tijdens zijn verblijf te Canton vernomen

1 Brief van Sir Matthew Decker aan Abraham Westerveen 14 Dec. 1731, 
had, hoe dit bedrog was gesmeed door den eersten carga de Jongh en hoe diens confraters, toen zij het gewaar werden, met den kapitein besloten hadden om de Jongh met list aan boord te lokken teneinde hem daar gevangen te zetten en zoo thuis te brengen, doch deze had er intijds de lucht van gekregen en de anderen weten te paaien door hen in den buit te laten deelen. Al wat die Engelsche carga hem had medegedeeld, verklaarde Decker, was naderhand door de meeste thuis gekomen schippers bevestigd. Hetgeen echter te Londen volgens den briefschrijver de meeste opspraak gaf was dit, dat de kooplieden die vandaar aan hun Amsterdamsche correspondenten hadden geschreven om te weten op wat manier de Bewindhebbers de zaak zouden behandelen, geen ander antwoord ontvingen dan dat er niets van werd gesproken, «ja de heer Decker zegt mij zelfs (dus schrijft hij) dat hij een brief heeft gezien, daarin gemeld wordt dat de Bewindhebbers den brief van de Chineesche kooplieden secreteeren, en dat zij dien aanzien als gefingeerd omdat men hen doet gelooven, dat er geen menschen tot Canton zijn die Duitsch ${ }^{1}$ verstaan: dat gansch contrarie is want drie Chineezen, die lange jaren tot Batavia hebben gewoond, aldaar zijn en die de Hollandsche taal in perfectie spreken.» ${ }^{2}$

Dat er hier te lande zulke beschuldigingen tegen de carga's uit China waren ingekomen, was inderdaad volkomen juist. Een paar dagen voor zij van daar de terugreis aannamen richtten diezelfde twee Cantonsche negotianten, die hun vóór en nà allerlei vriendelijkheden hadden bewezen en wier goede diensten zij in hun dagregister breed uitmaten, aan de Kamer Amsterdam een in het Hollandsch gestelden brief, waarin den carga's ten laste werd gelegd dat zij op voorgang van de Engelschen en Ostendenaars iedere pikol ingekochte thee tot 6 tael boven den koopprijs hadden aangerekend. Bovendien bezat de eerste carga de Jongh, volgens het schrijven der beide Chineezen, van de negotie en wel inzonderheid van thee geen de minste kennis hoegenaamd; trouwens de twee keeren dat hij in dienst van

1 D. i. Hollandsch.

3 Copie-brief (van den Raadpensionaris Slingelandt?) aan den „pensionaris de la Bassecour" (Jan de la Bassecour pensionaris van Amsterdam) van 5 Sept. 1730 , met bijgevoegd "extract uit een brief van Londen van den 1 Sept. 1730" (aan den Raadpensionaris Slingelandt?) in Kol. Arch. no. 11304. 
de Ostendenaars te Canton was over geweest had hij niet als carga doch maar als schrijver gefungeerd, zeggen zij. Tot het openbaren van deze dingen drong hen, zooals zij beweerden, behalve hun eerbied en liefde voor de Compagnie ook hun erkentelijkheid voor de groote diensten, indertijd tot vijfmaal toe te Batavia genoten toen ze daar met hun jonken ten handel waren geweest. ${ }^{1}$

Bij sommigen hebben die beschuldigingen niet veel indruk gemaakt zoo het schijnt. Men was, gelijk de toenmalige pensionaris van Amsterdam ergens verklaart, daar ter stede niet zeer overtuigd van de waarheid der gedane klachten en dat te minder wijl de carga's niet alleen het factuurboek zelfs tot de kleinigheden incluis zeer net hadden gehouden, maar ook omdat de twee eersten van hen het «zeer oneens waren, hetgeen men meende dat niet voorzichtig moest zijn in twee personen beide aan dezelfde vuiligheid of ontrouw schuldig." 2 Aan den anderen kant echter waren toch de Heeren Zeventien van oordeel dat de inlichtingen, hieromtrent door den schipper en twee van de carga's gegeven, "gansch niet voldoende" waren, weshalve zij besloten "om te zien of nog nadere elucidatie over deze zaak zou kunnen bekomen worden, waartoe de respectieve Kameren werden verzocht, en, bijaldien iets van deze zaak ontdekt zouden mogen hebben, daarvan communicatie aan de aanstaande vergadering (van de Zeventien) te geven, en dat ondertusschen door den heer Advocaat Westerveen ${ }^{3}$ aan den Compagnie'scorrespondent te Londen Gerard Bolwerk bij missive zou worden verzocht om, bijaldien eenige informatie over deze zaak konde suppediteeren, hetzelve aan zijn Edele te willen communiceeren. ${ }^{*}$ * Wat hierop is gevolgd laat zich niet meer nagaan: noch in de resolutiën der Zeventien noch in die van de Kamer Amsterdam wordt verder met eenig woord meer van de zaak gerept.

In denzelfden trant zette nu eenige jaren achtereen de Compagnie haar directe vaart op China voort. Telken jare, in

1 Brief van Tanhonqua en Chinquan aan de Kamer Amsterdam 29 Dec. 1730. Een latere brief van hen van 20 Jan. 1731 herhaalt de beschuldigingen nog eens (Papieren Coxhorn).

2 Brief van den pensionaris Jan de la Bassecour (aan den Raadpensionaris Slingelandt?) 6 Sept. 1730 (Kol. Arch. no. 11304).

3 De eerste Advocaat of Secretaris der Compagnie Abraham Westerveen,

4 Res, XVII 9 Sept. 1730. 
Augustus of September, bepaalden de Zeventien het getal van de derwaarts uit te zenden schepen, mitsgaders de hoeveelheid van zilveren specie en koopmanschappen, welke zij als bedrijfskapitaal zouden medenemen. ${ }^{1}$. Het in gereedheid brengen van de expeditiën zelve liet de vergadering van Zeventien aan die Kamers over, wier bodems voor de reis naar China werden aangewezen - op een tweetal reizen na, waaraan ook die van Zeeland deelnam, behoorden deze altijd aan de Amsterdamsche Kamer - hunne Bewindhebbers waren het, door wie de carga's, scheepsofficieren en bootsgezellen werden aangenomen, de zeilaasorders, reglementen en instructiën vastgesteld en de benoodigde contanten en koopwaren verschaft. ${ }^{2}$

Ook de negotie te Canton nam geregeld denzelfden loop als gedurende het verblijf van de Coxhorn aldaar in 1729. De carga's gingen er telkens na hun aankomst bij den hoppo ter audientie om vrijheid van handel te verzoeken, huurden al naar gelang van de behoefte een of meer factorijen, richtten banksaals $\mathrm{op}$, voorzagen zich van compradors, tolken en fiadors, aan welke laatsten zij somwijlen voor een ronde som in eens de betaling van het scheepsmetingsgeld, de mandarijnsrechten, en andere onkosten uitbesteedden, ${ }^{3}$ en sloegen vervolgens de hand aan het eigenlijke handelsbedrijf. Het meeste werk vorderde met alles wat daarmede gepaard ging het inslaan van porcelein en thee, waarvan jaar in jaar uit enorme voorraden door de onzen uit China werden overgevoerd. Van de ingekochte porceleinen, alle afgepakt in kassen, tobben (balies) of in met papier omwikkelde bondels, maakten het thee-, koffie- en chocoladegoed het hoofdbestanddeel, uit - er zijn schepen geweest die over de honderd- ja tot over de tweemaalhonderdduizend paren kopjes en schoteltjes naar Nederland wegsleepten - en daarbij kwamen dan nog de grootere en kleinere partijen van borden, kommen, trekpotten, patipans, schuitjes, melkkannetjes, thee- en suikerbusjes, koffie- en chocoladekannen, "gorgeletten", volledige thee- en tafelserviezen,

1 Res. XVII 14 Sept. en 21 Oct. 1730; 4 Sept. 1731; 19, 26 Aug. en 14 Oct. $1732 ; 8$ Sept. 1733.

${ }^{2}$ Res. XVII 5 Oct. 1731; 28 Aug. 1732; Res. Kamer Amsterdam 22 Aug., 12 en 22 Sept. en 17 Oct. $1729 ; 16$ Nov. $1730 ; 1$ Nov. 17 en 24 Dec. 1731; 10 en 13 Nov. 1732 ; 3 Dec. 1733; Res. Kamer Zeeland 20 Nov. 1730, 22 Nov. 1,10 en 27 Dec. 1731.

Res. en Dagregister carga's 30 Juli 1731; Dagregister 8 Aug. 1733. 
fruitschalen, boterschaaltjes, zoutvaten, olie- en azijnstellen, suikerpotten, "bagijnepotten, messeheften, koelbakken, punchkommen, kandeelkoppen, k klapmutsen, kaststellen, rozewaterfleschjes, kwispedoors en scheerbekkens. ${ }^{1}$ Van de thee, welke zoo vóór als nà het belangrijkste artikel bleef van de gansche negotie, sloegen de carga's van 1730-1734 een veel ruimer sorteering in dan hunne voorgangers van 1729: behalve in boei-, congo- en heysonthee, waartoe men zich destijds bepaald had, ${ }^{2}$ bestonden de ladingen, die dooreengenomen voor elk schip tusschen de 1142 à 2579 pikols beliepen, nog in partijen van souchon, bing, singlo, pecco, poutosang (powchong?) en soulang (oolong ?). ${ }^{3}$ De overige koopmanschappen, die men van tijd tot tijd medenam, hadden in vergelijking met de thee en het porcelein slechts weinig te beteekenen: het waren zijdestoffen, spiauter, radix-China, kwikzilver, zeldzamer ook ruwe zijde, radix-galinga, rhabarber, steranijs, aluin, parelmoer-

1 Blijkens de afpakboeken en verdere papieren van de schepen Duifje (teruggekeerd uit China in 1731), Leiduin (1732), Coxhorn (1732), Knappenhof (1733), Ypenrode (1733), Leiduin (1734), Voorduin (1734) en hunne cargalijsten uitgegeren in den Europischen Mercurius van 1731 II blz. 48, 1732 II blz. 107, 1733 II blz. 149, 1734 II blz 104, alsmede de cargalijsten van de schepen Nieuwrliet (1732), Anna Catharina (1734), Nieuwrliet (1734) en Noord Wolfsbergen (1735) in den Europ. Merc. van 1732 I blz. 292, 1734 II blz. 105 en 1735 II blz. 48. - Een gorgelet was volgens Hobson-Jobson, A glossary of AngloIndian words, i. v. goglet: „a waterbottle of globular body with a long neck."

2 Zie hiervoor blz. 81.

3 Blijkens de hiervóór aangehaalde afpakboeken enz. en cargalijsten werden medegebracht resp. door de schepen Duifje (1731), Nieuwvliet (1732), Leiduin met Coxhorn (1732), Knappenhof met Ypenrode (1733), Anna Catharina met Nieuwvliet (1734), Leiduin met Voorduin (1734), Noord Wolfsbergen, (1735) aan thee boei $180589,183714,338107,210421,318323,312870,205621$ kattis; aan congo $6513,10669,24183,82651,47118,112094,32519$ kattis; aan bing $21692,2900,22197,27185,5858,11331,6570$ kattis; aan singlo 12785,45781 , $86261,54860,20949,16015,8473$ kattis; aan souchong 4756, 2414, 4900, 44004, 21083, 41625, niets; aan heysan 2099, 3567, 10567, 37154, 8688, 2946, niets; aan pecco: niets, 5098, niets, 19720, 16460, 19089, 18428; aan poutosang en soulang door Nieuwvliet in 1732 (de overige schepen hebben van deze soorten niets overgevoerd) resp. 1122 en 1906 kattis. - Een katti was gelijk aan een honderdste van een pikol.

Over de hier genoemde theesoorten zie o. a. Peter Osbeck, Reise nach Ostindien und China, Rostock 1765, S. $206 \mathrm{ff}$; H. G. Hollingworth, List of the principal tea districts in China, in Journal of the North China Branch of the Royal Asiatic Society, New Series X, Appendix I; The Fan-Kwae or Canton before treaty days, London 1882 , p. 91-92. 
schelpen, Chineesche inkt, vermiljoen, roode verf, jalouziematten, snuisterijen en goud. ${ }^{1}$

Voor den inkoop van thee werden nu en dan met de Chineesche kooplieden contracten gesloten, bij welke zij zich verbonden om tegen den vastgestelden prijs en vrij van alle rechten en verdere onkosten een overeengekomen partij binnen korter of langer tijd aan boord van de schepen te zullen leveren. ${ }^{2}$ Een enkele maal kwam het voor dat men den fiador, ter vergoeding voor de aan het fiadorschap verknochte bezwaren en verplichtingen ${ }^{3}$, een recht van voorkeur moest geven "wanneer zijn thee met die van andere kooplieden egaal was." Zoo zegden de carga's van 1733 hun fiador op diens beding toe dat zij de voor hun bodems benoodigde hoeveelheid bij hem zouden inkoopen, mits zij in hoedanigheid en prijs die van anderen evenaarde en de

1 Blijkens de hiervóór aangehaalde afpakboeken enz. en cargalịsten werden overgevoerd aan zijdestoffen door Knappenhof met Ypenrode (1733) 800, Anna Catharina met Nieuwvliet (1734) 4597, en Noord-Wolfsbergen (1735) 2117 stukken; - aan spiauter door Nieuwvliet (1732) 40480, Leiduin met Coxhorn (1732) 34803, Knappenhof met Ypenrode (1733) 40125, Anna Catharina met Nieuwvliet (1734) 51509, Leiduin met Voorduin (1734) 80462, Noord-Wolfsbergen (1735) 55089 kattis; - aan radix China door Duifje (1731) 9625, Nieuwvliet (1732) 8119, Knappenhof met Ypenrode (1733) 6938, Anna Catbarina met Nięuwvliet (1734) 50748, Leiduin met Voorduin (1734) 11047, NoordWolfsbergen (1735) 6709 kattis; - aan kwikzilver door Duifje (1731) 100, Leiduin met Coxhorn (1732) 340, Knappenhof met Ypenrode (1733) 4200 kattis; - aan radix galinga door Knappenhof met Ypenrode (1733) 6000, Noord-Wolfsbergen (1735) 7620 kattis; aan rbabarber door Leiduin met Voorduin (1734) 440 kattis; aan ruwe zijde, steranịj, parelmoerschelpen en roode verf door Noord.Wolfsbergen (1735) resp. 81, 232, 8337 en 400 kattis; - aan aluin door Duifje (1731) 750 kattis; - aan Chineesche inkt en vermiljoen (cinabrum nativum) door Knappenhof met Ypenrode (1733) resp. 554 en 196 kattis; - aan jalouziematten, rozenhouten quadrilledoosjes met schijfjes van parelmoer, rozenhouten omberdoosjes met parelmoeren schijfjes en verlakte theeblaadjes door Anna Catharina met Nieuwvliet (1734) resp. 160, 152, 200 en 1620 stuks; - aan goud door Nieuwvliet (1732) 1766 tael en door Leiduin met Coxhorn (1732) $22811 / 5$ tael of omtrent 38221 onsen.

De radix galinga d.i. de wortel van de Kaempferia en de Maranta galanga, van een heeten, peperachtigen smaak en aromatisehen geur, werd hoofdzakelijk bij de bereiding van spijzen gebruikt; de steranijs, de vrucht van een in China wassenden heester, was zeer geschat om de olie die men er uit trok, en werd vooral uitgevoerd voor gebruik in de geneeskunde, zie Description of Canton, Canton 1839, pp. 162 en 133.

2 Contracten 20 en 21 Aug. 1730; Dagregister 3, 5, 6, 7, 9, 22, en 23 Sept. 1731; Contracten 14 en 16 Oet. 1732.

3 Zie hiervóór blz. 87. 
carga's, indien de waar bij anderen goedkooper mocht te verkrijgen wezen, "geenszins zouden geobligeerd zijn eenige negotie met hem te doen. ${ }^{1}$ Zulke contracten werden soms ook gesloten voor de zijdestoffen: in 1732 bestelden de carga's van de beide Hollandsche schepen de gansche massa bij één Chinees, die van zijn kant beloofde ze binnen drie maanden tijds aan boord te zullen bezorgen, alle uitgaande rechten en andere onkosten voor zijn rekening en met vrijheid voor de onzen om ieder stuk uit te schieten, dat niet voldeed aan de bij het contract vastgestelde lengte, kleur, enz. ${ }^{2}$ Goud, ofschoon op zichzelf een winstgevende koopmanschap daar het te Canton in vergelijking van het zilver veel minder waard was dan in Europa, ${ }^{3}$ kochten de carga's alleen dan in wanneer zij na het volstuwen van de schepen nog eenige contanten in hun kas over hadden. ${ }^{4}$ Wijl echter de Chineesche wetten allen uitvoer van goud verboden $^{5}$ moest men bij deze negotie zeer in het geheim te werk gaan en de duisternis van den nacht te baat nemen om de partij ter sluiks af te pakken en binnen boord te smokkelen. ${ }^{6}$

Anders dan in 1728 en 1729 toen de Compagnie louter muntspecie benevens eenig lood als ballast aan haar Chinavaarders medegaf, bevrachtte zij sommige van de schepen, die van 1730 - 1734 de reis naar Canton ondernamen, tegelijk met een partij Europeesche lakens, lakenrassen en spiegels. ${ }^{7}$ Veel wil heeft men van deze zoogenaamde "negotiegoederen niet gehad, het is waar de eerste maal dat zij die aanbrachten, in 1731,

1 Dagregister en Contract 20 Aug. 1732.

2 Dagregister en Contract 29 Aug. 1732.

3 Blijkens een ongedateerde notitie aan den Zeewschen Bewindhebber Samuel Radermacher (1730-1761) overgegeven door zekeren Adriaan Clemens, op grond van inlichtingen hem blijkbaar verstrekt door dienaren van de Compagnie van Ostende (Papieren Radermacher Kol. Aanw. 112), ruilde men te Canton 100 tael zilver voor 10 tael goud. Volgens Huisman, La Compagnie d'Ostende p. 293, was in het eerste vierendeel der $18^{\circ}$ eeuw de waardeverhouding van goud tot zilver in China $=1: 10$, in Europa $=1: 15$. Olof Toreen, Ostindische Reise nach Suratte, China etc. (April 1750-Juni 1752), Rostock 1765, S. 502, vermeldt dat op zijn reis het goud te Canton $14 \frac{1}{2}$ maal zooveel gold als het zilver.

4 Dagregister 19 December 1731 en 19 Januari 1733.

${ }^{5}$ C. Lockyer, Beschrijving van den koophandel in Oostindiën (omstreeks 1711), Amst. 1753 , blz. 77 ; C. F. Noble, A voyage to the East Indies in 1747 and 1748, Londen 1762, p. 316; Dagregister 30 Dec. 1731, 4 Januari 1758.

6 Dagregister 30 en 31 Dec. 1731.

7 Blijkens de facturen en andere papieren der schepen werd naar China uitgevoerd door Leiduin (1730), Coxhorn (1730), Leiduin (1732), Voorduin 
gelukte het aan de carga's hun voorraad al vrij spoedig tegen contanten te verkoopen, ${ }^{1}$ doch den anderen keer, in 1733, moest er als het ware mede worden geleurd: ten gevolge van den grooten aanvoer door de Engelschen en Franschen waren de lakenen toen ter tijd zoo weinig in trek te Canton dat de onzen de hunne - eerst na eindeloos geloop en gedraaf en dan nog maar alleen door inruiling tegen Chineesche waren konden kwijt raken. 2 . Dit laatste was trouwens haast de eenige manier waarop het omzetten van Europeesche koopmanschappen te Canton mogelijk was. "Het is onmogelijk (zeggen de carga's van 1731 ergens) voor contant hier iets te verkoopen ja al wilde men zijn goederen voor half geld geven, doordien de Chineezen in het generaal geen geld willen relâcheeren, zoodat wij bevinden dat alle Europeesche goederen in negotie niet kunnen rendeeren, want hetgeen naar oogenschijn daarop gewonnen zou worden, in het troqueeren ${ }^{3}$ weder moet verliezen, buiten en behalve dat men daarmede zoude risqueeren om meerder te koopen als men kon laden, dewijle de Chineezen de goederen niet eerder willen aanzien voor en aleer zij omtrent weten dat de contanten omtrent besteed zijn en alzoo geen hoop hebben het restant harer thee te verkoopen." 4

In het beleid van den handel, aanvankelijk geheel opgedragen aan de carga's, ${ }^{5}$ hadden naderhand op order van de Bewindhebbers de schippers eveneens zeggenschap. ${ }^{6}$ Zoo dikwijls er

(1732) aan lakenen resp. 538, 4941 $\frac{1}{2}, 2562 \frac{1}{2}$ en 2674 ellen, aan lakenrassen resp. $184,185 \frac{1}{2}, 705 \frac{1}{2}$ en $708 \frac{1}{2}$ ellen. Van uitvoer van spiegels blijkt uit tal van plaatsen in de dagregisters van Leiden en Voorduin van 1733. De schepen Duifje (1729), Knappenhof en Ypenrode (1732), alle van de Kamer Amsterdam, hebben geen lakenen of andere negotiegoederen naar China uitgevoerd. Van het Amsterdamsche schip Noord-Wolfsbergen (1734) en de voor de Kamer Zeeland uitgevaren Chinavaarders Nieuwvliet (1730), Anna Catharina en Nieuwvliet (1732) zijn geen facturen of papieren overgebleven.

1 Dagregister 31 Aug., 1 en 7 Sept. 1731.

2 Dagregister 24 Aug., 2, 25, 30 Sept., 12, 15-17, 22 Oct., 5 en 27 Nov. 1733.

3 Ruilen, van het Portugeesche trocar.

4 Dagregister 8 Oct. 1731.

${ }^{5}$ Blijkens de reglementen vastgesteld door de Kamer Amsterdam bij resolutiën 15 Nov. 1728 en 16 Nov. 1730.

6 Blijkens als voren 1 Nov. 1731,13 Nov. 1732,3 Dec. 1733. Bij resolutie Kamer Zeeland 22 Nov. 1731 werd goedgevonden "te continueeren in deze Kamer's maximes dat benevens de cargadoor Andries Boele en verdere cargadoors de schipper Brand (n.l. van het voor China uitgereede schip Anna Catharina) mede in de zaken van negotie zal moeten worden gekend zoo en in dier voege als met schipper Fiers op (het insgelijks voor China uitgereede schip) Nieuw vliet is verstaan." 
meerdere Compagniebodems tegelijk voor Canton lagen, die tot verschillende Kamers behoorden, dreven hunne carga's en schippers den handel al te zamen in gemeen overleg, ${ }^{1}$ of kwamen zij overeen, gelijk in het najaar van 1733 gebeurde, "dat de twee Hollandsche schepen, als voor één Kamer (n.l. Amsterdam) zijnde, de negotie gezamenlijk zouden doen, zoo mede de twee schepen van Zeeland met haar beide de negotie zouden doen, doch met deze accoord dat men de prijzen niet tegen den anderen zoude opjagen en malkander kennis geven van het rijzen der goederen." ${ }^{2}$ Op wat voet hun handelsvrijheid van wege de Chineesche overheid was geregeld, toonen de bepalingen welke den 2 September door den "grootmandarijn van de tolhuizen van al de havens van Canton" " 3 aan de vreemde factorijen werden rondgezonden in antwoord op een verzoekschrift van de carga's der Engelsche Compagnie. De Engelschen hadden namelijk in dit stuk geklaagd dat men hun te Canton nog veel grooter "extravagantie van rechten" afvergde dan voorheen in de havens van Ningpo, Tcheou (?) en Amoy, welke zij juist om die reden hadden verlaten voor Canton, en er bij gevoegd dat zij zich zouden genoodzaakt zien thans weder van Canton naar andere havens te vertrekken, waar hun mogelijk een beteré behandeling te wachten stond, zoo niet te hunnen behoeve de "aloude en te voren geetablisseerde usantie" hersteld, en de volgende voorrechten toegekend werden: $1^{\circ}$ verlof om te koopen en te verkoopen van en aan wien zij verkozen; $2^{\circ}$ verlof om te kiezen een tolk, comprador en knechts naar eigen goedvinden zonder verplicht te zijn "tjap daarvoor te betalen", opdat zij daarvan konden veranderen en anderen kiezen zoo vaak het hun geraden docht; $3^{\circ}$ dat noch zijzelf noch de Chineesche kooplieden, met wie zij kwamen te handelen, meer aan rechten zouden hebben te betalen dan in het tarief was bepaald; $4^{\circ}$ dat hun geldspeciën vrij zouden wezen van alle rechten; $5^{\circ}$ dat het hun vrij zou staan voor hem, grootmandarijn hoppo, te verschijnen wanneer zij eenige klachten mochten hebben; $6^{\circ}$ dat de benoodigdheden voor de factorij als bier, wijn enz. geen de

' Dagregister 13 Augustus 1731: besloten om "het gros der negotie" door de drie Compagnie's schepen (t. w. Leiduin en Coxhorn van Amsterdam en Nieuwvliet van Zeeland) te zamen te doen.

2 Dagregister 2 Oct. 1733.

s Met andere woorden den hoppo. 
minste rechten zouden moeten betalen, alsmede dat het hun vrij zou staan vee te slachten en op hun vertrek uit China hun vleesch, gevogelte en andere provisiën aan boord te brengen zonder betaling van rechten, en dat de kapiteins op Wampoo dezelfde gunst mochten genieten; ${ }^{1} 7^{\circ}$ dat hun vrijheid werd verleend om de vlag te voeren op hun chaloep en "dat het verboden (zou) worden aan alle de officieren van den hoppo en alle andere mandarijns van dezelve te visiteeren of achtervolgen (als zij kooplieden of kapiteins daarin zouden zijn), want hetzelve (zeggen zij) ons een disrespect is en het is ook een privilegie, daar de Europeanen van jouisseeren van over lange tijden en hun in den jare 1727 vernieuwd is;" $8^{\circ}$ dat men niet toelaten zou dat bij hun banksaal op Wampoo punch- of samsoehuizen ${ }^{2}$ gebouwd wierden, om te verhoeden dat door dronkenschap van hun matrozen vechterijen ontstonden; $9^{\circ}$ verlof om al wat zij tot het kalefaten van hunne schepen behoefden te koopen vrij van rechten; $10^{\circ}$ verlof om "te mogen afschepen alle de koopmanschappen, die op hun naam waren, mits zelf de rechten daarvan betalende, zonder verplicht te wezen daartoe steeds Chineezen te gebruiken; $11^{\circ}$ dat, "ingeval aan de tolhuizen koopmanschappen van matrozen of anderen, die wilden fraudeeren, geconfiskeerd werden, men verder niet aan eenige boete gehouden» zou wezen, zullende zij van hun kant niet in gebreke blijven dezulken te straffen, die op eenige wijze de rechten zouden "fraudeeren;" $12^{\circ}$ dat men hun geen nieuwe rechten zou afvorderen hetzij van inkomen, meten van schepen als anderszins onder wat voorwendsel ook; $13^{\circ}$ dat, als zij zouden moeten afschepen of goederen laten van- of aan scheepsboord komen of gaan, hun dit zonder verwijl zou veroorloofd worden en dat, wanneer al hun goederen aan boord gebracht en alle verschuldigde rechten door hen voldaan waren, men ze niet zou verletten maar hun leveren het tjap van vertrek. Mochten die dertien artikelen niet worden ingewilligd dan, zoo verklaarden zij ten slotte, zouden zij met hun schepen, die op stroom de beslissing lagen af te wachten, wederom keeren en naar een andere Chineesche haven verzeilen. Een bedreiging die klaarblijkelijk

1 Ten behoeve namelijk van het scheepsvolk, dat aan boord van de schepen ter reede van Wampoo achterbleef.

2 Samsoe was een geestrijke drank uit rijst gedistilleerd, zie C. F. Noble, A voyage to the East Indies in 1747 and 1749, London 1762, p. 153. 
gewicht in de schaal heeft gelegd, want in zijn antwoord gaf de hoppo de verhuurders van de factorijgebouwen, de tolken, de ambtenaren van de tolhuizen en anderen wel uitdrukkelijk bevel om de vreemdelingen niet te misleiden, te verachten of te bedriegen, en bepaalde voorts dat het aan de kooplieden van "alle hier arriveerende vreemde schepen» vrij stond een factorij uit te kiezen, die zij het best geschikt achtten, alsmede dat zij die tolken en compradors mochten aannemen, welke zij gewend waren, of andere, die zij dienstig zouden bevinden, echter zouden dezen zich bij hem moeten aanmelden «ten einde hij hun een tjap gave, en door dien middel zouden zij de vreemdelingen niet durven misleiden, bestelen en wegvluchten; wat de rechten op de koopmanschappen en voor het meten van de schepen aanging, zouden zij zich hebben te reguleeren naar de oude wetten ten einde hij dezelve zonder difficulteit genieten en ontvangen" kon; de kooplieden van de factorijen ${ }^{1}$ en de tolken zouden zich niet mogen bedienen van eenige "toeren of streken om eenig geld van de vreemden "af te nemen op zijn naam of gezag op wat pretext het zoude mogen wezen;» de passagerechten van eet- en drinkwaren en andere kleinigheden, dienende tot onderhoud van de vreemdelingen, werden geheel door hem afgeschaft; de kapiteins en supercarga's mochten in hun chaloep, vlag voerende, gaan en komen zonder de tolhuizen aan te doen doch het werd hun verboden "eenige plaatse aan te doen, goud te sluiken of andere koopmanschappen, verboden door den keizer, w werden zij daarop betrapt, zoo zouden zij gestrengelijk gestraft worden; van hetgeen de schepen noodig hadden van zeil- en touwwerk behoorden zij een nette lijst op te maken en dan zou er een tjap worden verleend dat men alles mocht inkoopen, doch van die permissie zou men geen gebruik mogen maken "om zooveel te koopen dat men hetzelve uit het land zoude transporteeren; bij het afschepen van goederen en koopmanschappen moest een van de eerste kooplieden hem opgeven wat zij wenschten af te schepen, opdat de beambten van de tolhuizen het alles recht nazien en wegen konden; aan de Chineezen werd verboden op de reede van Wampoo punchhuizen te bouwen of wijn, arak, samsoe en punch te verkoopen; eindelijk werden de beambten van de

1 D. i. de Chineesche kooplieden, die met de carga's der vreemde factorijen handelden. 
tolhuizen gelast de matrozen of anderen, die mochten willen "fraudeeren, " aan te houden en hem van de aanhouding te verwittigen, zullende hij alsdan de delinquenten straffen, echter *zonder daarom eenige de minste moeite aan de vreemde kooplieden te doen. ${ }^{\prime}$

Aan bijzondere knevelarijen schijnen nu in de eerstvolgende jaren de vreemde kooplieden te Canton niet meer te hebben bloot gestaan. Het is waar, toen er in 1732 tijdens hun aanwezen aldaar een nieuwe hoppo of oppertolmeester was aangesteld en zij bij dezen hun opwachting makten, richtten de onzen het verzoek tot hem om de «zware tollen» te verlichten. waarmede zijn voorganger alle koopwaren had belast, maar misschien heeft men hierin veeleer een poging te zien om uit de bestuurswisseling een voordeeltje te slaan dan een bewijs dat de vorige hoppo inderdaad hoogere rechten had gevorderd dan hem toekwamen volgens de oude verordeningen, welke bij de beschikking van 2 September 1730 uitdrukkelijk waren gehandhaafd. ${ }^{2}$ Ook wordt in de papieren van de Compagniesschepen, die in 1731-1734 voor Canton ten handel hebben gelegen, verder maar eenmaal meer van de rechten gerept; bij gelegenheid van de gebruikelijke afscheidsaudientie namelijk in Januari 1734 drongen de Hollandsche carga's er bij den hoppo op aan in het toekomende de rechten, tollen en onkosten wat te modereeren, " wat hun, naar het dagregister vermeldt, beloofd werd. ${ }^{3}$ Bovendien stonden hun probate middelen ten dienste om den last iets minder drukkend te maken. Wie geen al te nauwe visitatie van zijn goederen verlangde kon met een zoet geschenkje nu en dan aan de beambten van den hoppo, tot de hoogstgeplaatsten incluis, wonderen doen. ${ }^{4}$ Zonder fooien en presenten trouwens viel er aan geen handel met de Chineezen te denken. 5 Zelfs namen de hoppo's op de afscheidsaudienties meer dan eens de vrijheid om aan onze carga's nauwkeurig op

1 Request van de Engelsche superearga's aan „den grootmandarijn van de tolhuizen van al de havens van Canton" en diens antwoord daarop den $2^{\mathrm{en}}$ Sept. 1730 ngezonden aan de factorijen van vreemde kooplieden" (Papieren van het schip Duifje 1729/30).

2 Dagregister 11 Oet. 1732.

3 Dagregister 4 Januari 1734.

${ }_{4}$ Vgl. C. Lockyer, Beschrijving van den koophandel in Oost-Indiën, Amst 1753 , blz. 57.

5 Zie hiervóór blzz. 76, 97, 98. 
te geven wat geschenken zij begeerden dat men den volgenden keer voor hen uit Europa zoude medebrengen: spiegels van het allergrootste formaat, kleine Spaansche of Bologneesche hondjes, gouden repetitiehorloges, goudlakens, pelterijen van sabelbont en wat dies meer zij. ${ }^{1}$

Hebben alzoo de onzen denkelijk geen last gehad van formeele knevelarijen, aan den anderen kant veroorzaakte de willekeur der Chineesche overheid hun bij wijlen een uiterst hinderlijk oponthoud. Zoo bij voorbeeld in 1733. Nadat de carga's den 20 December als dag van vertrek hadden bepaald, ${ }^{2}$ lieten zij in het begin van de maand door middel van een paar Chineesche kooplieden alvast het daarvoor vereischte "groote tjap " ${ }^{3}$ aanvragen, doch kregen van dezen te hooren "dat er present geen gelegenheid was om bij de hoppo's iets te verrichten alzoo zijlieden bezig waren met alles te laten prepareeren tot het celebreeren van den aanstaanden geboortedag, die den 13 dezer zoude zijn van den "imperador of viceroy van Canton, en waartoe $z \mathrm{ij}$ - dagelijks vele mandarijns en andere voorname Chineesche grooten van Peking en van elders, die in menigte aankwamen, verwachtten en van de reeds gearriveerde continueel bezoek hadden, zoodat de Chineesche kooplieden ook niet hare negotie daarom konden voortzetten dewijl er geen tjappen zouden noch werden verleend, weshalve de onzen, zeiden zij, tot na dien tijd zouden moeten wachten. ${ }^{4}$ Den 10 December herhaalden de carga's hun verzoek, er met nadruk op wijzende dat zij te Canton niet langer konden blijven aangezien hun negotie was afgeloopen en zij noodig vertrekken moesten. Den 11 en 12 December deden zij het verzoek op nieuw doch zonder met al hun bidden en smeeken ook maar een schrede vooruit te komen; zij ontvingen geen antwoord of moesten van de Chineesche handelsvrienden, wier tusschenkomst zij hadden ingeroepen, vernemen dat het onmogelijk was geweest gehoor te verkrijgen. Ja zelfs nadat de feestelijke viering van den jaardag des onderkonings op 13 December goed en wel was afgeloopen, kwam er nog geen schot in de zaak, want toen de carga's twee dagen na dien andermaal om het groote tjap aanhielden,

1 Dagregister 29 Dec. 1731 en 4 Januari 1733.

2 Dagregister 1 Dec. 1733.

3 Zie hiervóór blz. 35.

4 Dagregister 7 Dec. 1733.

Dl. 73 
daar zij "absoluut wilden vertrekken» werd hun beduid, dat zij "daaraan niet moesten denken binnen een à twee dagen, alzoo bij de hoppo's nog bij continuatie de vreugde werd gecontinueerd en dat ook daarom verscheidene mandarijns nog onlangs waren aangekomen en nog stonden te komen. ${ }^{1} \mathrm{Na}$ hun nieuwen, alweder vruchteloozen, aandrang op 17 en 18 December ${ }^{2}$ werden de Chineesche autoriteiten klaarblijkelijk bevreesd dat de Hollanders uit bezorgdheid dat het gunstige seizoen voor de terugreis ten eenenmale zou verloopen, ${ }^{3}$ zich heimelijk uit de voeten zouden maken en eigenmachtig met hun schepen doorgaan. In den nanacht toch van den 18 December kwam de Chineesche tolk geheel ontsteld de factorij binnenstuiven, "zeggende (zooals de carga's in hun dagregister hebben aangeteekend) dat hij uit ordre van de mandarijns door ordre van de hoppo's was opgewekt om in dezelve factorij te gaan, dewijl voorschreven mandarijns waren bericht (hoewel ten onrechte en onwaarheid) dat wij trachtten om ter sluips van hier te vluchten, ook dat er twee gewapende champans achter onze factorij waren kruisende om de (gewaande) vlucht te beletten, maar (zeggen de carga's) nadat de gemelde lingua van het tegendeel door ons was bericht ging dezelve weder heen om daarvan rapport te doen. ${ }^{4}$ Daags daaraan stuurden de onzen in hun ongeduld de beide Chineesche kooplieden opnieuw uit om hun afscheidsgehoor en groote tjap aan te vragen; zij begaven zich terstond naar het kantoor van de hoppo's maar konden daar ongelukkig ook nu niets gedaan krijgen, "dewijl de hoppo's (gelijk zij aan onze carga's mededeelden) nog geoccupeerd werden van den gepasseerden imperadors geboortedag, overzulks (men) nog wat geduld moest hebben en wachten. ${ }^{5}$ En op dien trant ging het gedurig voort. Toen de Hollanders, na daags te voren wederom hun verzoek te hebben ingediend, den 23 December nog eens lieten hooren, bleken de heeren nog al niet van het feestvieren te zijn verzadigd: zij waren nu met een deel andere Chineesche grooten uit de stad naar buiten vertrokken om daar eenige dagen hun vermaak te nemen en nieuwe feestelijkheden

\footnotetext{
1 Dagregister 10, 12, 13 en 15 Dec. 1733.

' Dagregister 17 en 18 Dec. 1733.

3 Zie hiervóór blz. 35.

4 Dagregister 18 Dec. 1733.

s Dagregistér 19 Dec. 1733.
} 
aan te richten, ${ }^{1}$ maar binnen een dag of acht, met dit bescheid werden de onzen een paar dagen later in antwoord op een nieuwe aanvraag getroost, binnen een dag of acht zouden de heeren wel van hun landtochtje terug zijn en dan zou hun het verzochte afscheidsgehoor benevens het tjap worden verleend. ${ }^{2}$ Dat de hoppo's ten slotte vroeger wederkeerden dan men verwacht had - den 20 December kwamen zij in de stad terug - gaf voorshands weinig baat want na de veelvuldige vreugdebedrijven gevoelden zij zich te vermoeid om zich het hoofd te willen breken met zaken doen of audienties geven. ${ }^{3}$ Eerst op den 2 Januari 1734 waren zij blijkbaar weer zoo ver op krachten gekomen dat zij zich bekwaam gevoelden om de Hollanders het groote tjap te bezorgen, edoch zij lieten dezen meteen weten dat zij hen niet voor overmorgen op audientie konden wachten wijl zij "heden door den jonting werden getracteerd. ${ }^{4}$ Findelijk, eindelijk kwam er aan de lange geduldoefening van de onzen een einde. Den 4 Januari 1734 gingen zij in plechtig gehoor van de hoppo's afscheid nemen en daags daaraan zeilden de Compagnieschepen de Cantonrivier af om de terugreize te aanvaarden naar het Vaderland. ${ }^{5}$

In het geheel zijn gedurende het tijdperk 1728-1733, dat is zoolang de directe vaart uit Nederland naar Chiná in zwang is geweest, zes tochten door de Compagnie derwaarts ondernomen, en dat wel met negen bodems van de Amsterdamsche en drie van de Zeeuwsche Kamer. Naar een opgave te oordeelen van den bekenden Thomas Hope, ${ }^{6}$, die sedert 1766 den Prins van Oranje als Opperbevelhebber der Compagnie representeerde, hebben die Amsterdamsche schepen, ${ }^{7}$ na aftrek van alle onkosten en lasten, aan zuivere winst in guldens en stuivers de navolgende bedragen opgeleverd:

1 Dagregister 22 en 23 Dec. 1733.

2 Dagregister 25 Dec. 1733.

3 Dagregister 30 Dec. 1733.

4 Dagregister 2 Januari 1734.

${ }^{5}$ Dagregister 4 en 5 Januari 1734.

${ }^{6}$ „Consideratiën omtrent eenige artikelen rakende den handel op China, waarvan Zijne Hoogheid informatie heeft gerequireerd," door Hope opgesteld omstreeks 1751.

7 De winsten van de Zeeuwsche schepen (Nieuwvliet 1730/32, Anna Catharina $1732 / 34$ en Nieuwvliet $1732 / 34$ ) worden niet opgegeven. 


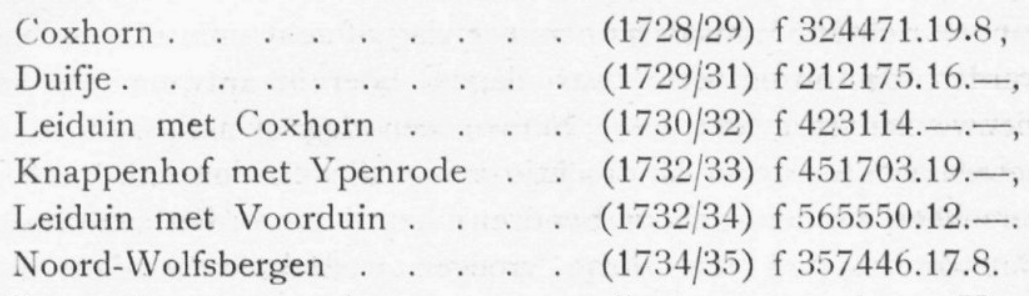

De verliezen, op de voyages gevallen, waren volgens Hope veroorzaakt door de schipbreuk van de kiel Buren, welke in het jaar 1729 uitliep insgelijks de wil hebbende naar China doch even buiten Tessel op de Haaks verzeilde en met nagenoeg de gansche lading verging. ${ }^{1}$

Op den duur nochtans vermocht de directe Chinasche vaart trots haar belangrijke winsten de Bewindhebbers niet te bevredigen. Daarvoor gingen naar hun oordeel de reizen met te veel kosten gepaard. Vandaar dat de Kamer Amsterdam in Augustus 1732 aan een commissie uit haar midden opdracht gaf om na te gaan "wat menage in deze expeditiën zou kunnen gepractiseerd worden terwijl de Vergadering van Zeventien een paar dagen later aan eenige gecommitteerden eveneens verzocht "om te besogneeren of niet eenig redres zou kunnen worden gemaakt in het equipeeren naar China tot menage van de Compagnie zoo in het verminderen van het getal der medegaande carga's, scheepsofficieren, matrozen en andere zaken. ${ }^{2}$ Het gevolg was dat op het personeel aanmerkelijk werd bezuinigd. Op de eerstvolgende reis, zoo verordineerden de Zeventien, zou men aan boord van de Chinavaarders niet langer drie kooplieden of carga's plaatsen maar slechts één supercarga met een maandgeld van 120 gulden, vrij wat minder dus dan tot hiertoe door den eersten carga was genoten, ${ }^{3}$ mitsgaders een assistent van 24 gulden, die den supercarga moest bijstaan in de negotie en tevens gedurende de reis de scheeps-

1 Consideratiën van Thomas Hope. Het schip is blijkens de resol. Kamer Amsterdam van 12 Dec. 1729 en 9 Febr. 1730 verongelukt in den nacht van 9 op 10 Dec. 1729. Volgens haar resol. van 29 Sept. 1729 moet het aan zilveren muntspeciën een waarde hebben ingehad van $2 \frac{1}{2}$ ton gouds. Pogingen om hiervan nog wat op te visschen, waarvoor de Kamer eerst met iemand uit Makkum en later met een Engelschen „duikelaar" overeenkomsten aanging, schijnen volslagen te hebben gefaald, vgl. haar resol. van 26 Januari, 9 Febr., 4 Mei, 9 Nov. 1730 en 18 Juni 1731.

2 Resol. Kamer Amsterdam 14 Aug. 1732 en van de Zeventien 19 Aug. 1732.

3 De maandgelden van den eersten, tweeden en derden carga op de Amsterdamsche Chinavaarders hadden te voren bedragen resp. 150, 120 (of 50) en 50 gulden, op de Zeeuwsche resp. 100 (of 135), 75 (of 135), 24 (of 50) gulden. 
boeken houden, terwijl de plaats, te voren in handelszaken door den derden van de carga's ingenomen, nu door den schipper zou vervuld worden, en het werk van de schiemans, bootsmans, botteliers en botteliersmaats, die geheel werden afgeschaft, voor rekening werd gelaten van anderen uit de bemanning; ${ }^{1}$ altemaal maatregelen die, zoo zij de Compagnieskas een niet te versmaden verlichting aangebracht hebben, toch bezwaarlijk een groote stijging van het winstcijfer kunnen hebben veroorzaakt. ${ }^{2}$ Wat de Bewindhebbers mogelijk almede van de rechtstreeksche vaart op China af keerig heeft gemaakt, moet de ontrouw zijn geweest van verscheidene carga's en andere opvarenden van de schepen. "Wij zullen," zoo schrijft Thomas Hope in zijn omstreeks 1751 opgestelde consideratiën over den Chinaschen handel, "wij zullen geen gissinge maken waarinne al die inconvenienten (der directe vaart) zouden hebben mogen bestaan," op welke de Zeventien in hun brief aan de Hooge Indische regeering van 1733 doelen, "dewijl de Vergadering van Zeventien die niet specifiek aanhaalt, maar het komt zeer apparent voor dat daarmede zal zijn gebuteerd onder andere op de procedures, die men tegens diverse officieren dier schepen over hun zeer verregaande wangedrag heeft moeten houden, in zoo verre dat de Hoofdofficier dezer stad ${ }^{3}$ tegen hen crimineelijk heeft geprocedeerd en de Compagnie diverse uit haar dienst heeft gedeporteerd en zich in procedures moeten inwikkelen, waarvan zij zelfs nu nog maar voor twee jaren geleden een einde heeft kunnen krijgen. ${ }^{4}$

1 Resol. XVII 26 Aug. en 14 Oct. 1732.

2 Men schijnt er trouwens ook in het vervolg niet de hand aan te hebben gehouden want op het in 1734 voor China uitgeruste schip Noord Wolfsbergen waren twee eerste, een tweede en een derde carga geplaatst met een maandgeld resp. van 150,120 en 80 gulden.

D. i. van Amsterdam.

4 "Consideratiën omtrent eenige artikelen rakende den handel op China, waarvan Zijn Hoogheid informatie heeft gerequireerd," omstreeks 1751 door Thomas Hope overgegeven aan Prins 'Willem IV. - Aan het wangedrag, daar Hope van spreekt en dat hoofdzakelijk schijnt te hebben bestaan in het medebrengen van meer goederen voor eigen rekening dan de reglementen aan de opvarenden toestonden, heefo men zich blijkbaar vooral schuldig gemaakt op de in 1733 teruggekeerde schepen Knappenhof en Ypenrode. Verscheidene resolutiën van de Kamer Amsterdam over 1733-1741 vermelden dat deswege de kisten van ettelijke carga's en officieren aangehouden zijn geworden, met het gevolg dat daaruit weder gedingen zijn voortgesproten voor de schepenbank, die in sommige gevallen ten slotte door de partijen bij schikking zijn afgedaan, 
Bovendien bleek de directe handel op China volstrekt onmachtig te zijn om de Europeesche concurrenten, gelijk men gehoopt had, uit het vaarwater te weren. ${ }^{1}$ Zelfs onze oude mededingster, de Compagnie van Ostende, hoewel door de schorsing in Mei 1727 voor zeven jaar onschadelijk gemaakt zoo het scheen, ${ }^{2}$ had middelerwijl het hoofd weer opgericht en haren handel op China hervat. Omstreeks Kerstmis 1729 verliet een aan haar toebehoorend schip, De Keizerin geheeten, de haven van Ostende met bestemming naar Cadix. Nadat men het bij zijn aankomst voor de leus had verkocht aan een daar gevestigd Iersch koopman en het bevel was overgenomen door den kapitein van een anderen Ostendischen bodem, De Aartshertogin, dien de Compagnie voor oorlogsschip aan Spanje van de hand had gedaan, liep het schip, nu als De Apollo herdoopt, weder in zee onder keizerlijke vlag en met geen andere lading aan boord dan ettelijke kisten vol muntspecie. Zooals de kapitein aan zijn onderhebbend scheepsvolk meedeelde ging de reis naar de Straat van Gibraltar en de Middellandsche zee; naderhand toen zij bemerkten dat De Apollo een andere richting insloeg, wendde hij voor dat hij naar West-Indië wilde. Doch eenmaal in het ruime sop gekomen liet hij koers zetten naar China, vertoonde op zijn tocht bij ontmoeting van andere vaartuigen al naar gelang van hun nationaliteit allerlei vlaggen, Engelsche, Fransche, Hollandsche, en kwam in Augustus 1730 behouden voor Canton tot niet geringe verbazing van de carga's van het Hollandsche schip Duifje, die de Hooge Regeering te Batavia eerlang van het geval verwittigden. Ofschoon de officieren voorgaven een pas te bezitten van den koning van Pruisen, z.oo kon toch De Apollo, schreven onze carga's, onmogelijk een Pruisische bodem zijn maar hoorde hij stellig thuis te Ostende. In het laatst van Juli 1730 , voegden zij er bij, hadden zij op hun heenreis De Apollo in Straat Banka ontmoet, hij voerde toen een Engelsche vlag, doch had die naderhand in het passeeren van Macao met een keizerlijke verwisseld en deze laatste op de reede van Wampoo weer vervangen door een Pruisische, alles bewijs genoeg naar hun inzien dat "deze wagen nooit recht ging." Vroeg men aan officieren en scheepsvolk van wat plaats

1 Zie hiervóór bl\%. 64, 65.

2 Zie hiervóór blz. 58. 
zij kwamen, dan luidde het antwoord: van Koningsbergen; niettemin hadden de onzen den kapitein in eigen persoon hooren zeggen dat hij zijn Pruisische vlag zelf had laten schilderen maar dat, als die niet docht, zijn pas het zou goed maken. ${ }^{1}$

Ondertusschen was het bedrijf der Ostendenaars ook in Europa uitgelekt. Op het allerlaatst van November 1730 zond de Nederlandsche gezant in Engeland, Hendrik Hop, het bericht over hoe men daar te lande vernomen had dat twee schepen, voor eenigen tijd van Ostende naar Cadix uitgeloopen, laatstgenoemde haven weder verlaten hadden en met Pruisische vlaggen naar Indië waren gezeild. De Directeuren van de Engelsche Compagnie, meldde Hop, hadden tegen dit bestaan bereids hun maatregelen genomen door het uitvaardigen van een bevel om de tegenwoordig uitgaande schepen der Ostendenaars, waar men ze tegenkwam, te vermeesteren of te vernielen. ${ }^{2}$ Straks werd het voorbeeld van de Engelsche door onze Compagnie nagevolgd. Met goedvinden van de Staten-Generaal gaven nog voor het jaar was verstreken de Bewindhebbers aan hun Indische bedienden last om desgelijks te handelen. ${ }^{3}$ Dat de onzen inderdaad voor geen geweld terugdeinsden werd De Apollo gewaar op de terugreize. Omtrent Straat Malakka komende ontmoette hij een vijftal Compagnieskruisers, die hem aan een scherpe vervolging onderwierpen maar aan wier greep hij ten slotte wist te ontsnappen, dank zij «de stoute resolutie van den kapitein, die alles op zijn welzeilen liet afloopen en de verwonderenswaardige echappade makkte, " gelijk met onverholen bewondering voor het zeemanschap van den tegenstander door een van de Engelsche Compagniesdirecteuren zelf wordt getuigd. ${ }^{4}$ Het schip zette nu onverhinderd zijn reis voort tot aan de Kaap, verschalkte daar weder een paar Engelsche oorlogsfregatten, en viel ten slotte in

1 Brieven van den earga Gerard de Bock c.s. uit Canton aan GG en RR. 1 en 9 Dec. $1730 ;{ }_{n}$ Kort detail van hetgene ik heb kunnen naspeuren op het subject van het schip De Appollo" overgezonden uit Hamburg door den resident Mauricius; Notarieele verklaringen door een tweetal opvarenden van De Apollo ter requisitie van de Bewindhebbers afgelegd te Amsterdam op 17 Nov. 1731; Huisman, La Compagnie d'Ostende, p. 460.

2 Brief van Hop aan de Staten-Generaal 28 Nov. 1730.

s Resol. Kamer Amsterdam 14 Dee. 1730, en van de Staten-Generaal 15 Dec. 1730.

4 Brief van Sir Matthew Decker aan den Eersten advocaat der Hollandsche Compagnie Abraham Westerveen 3/14 Dec. 1731. 
September 1731 ongedeerd te Hamburg binnen. Met dat al zou den Ostendenaars zelfs thans nog de vrucht van huñ welgeslaagde onderneming ontgaan zijn indien de Hamburgsche Senaat minder fermeteit had betoond. Wat moeite Engeland en de Republiek aanwendden om gedaan te krijgen, dat hij De Apollo wegens tractatenschennis in beslag nemen en de lading confiskeeren zou, de Senaat liet zich door geen Engelsch-Hollandsche protesten, eischen of dreigementen overhalen tot iets, dat in zijn oogen gelijk stond met het prijsgeven van Hamburg's aloude handelsvrijheden. Hij liet daarom de aangekondigde veiling van de koopmanschappen, welke De Apollo had medegebracht, onverlet doorgaan en stelde zoodoende de Ostendische Compagnie in de gelegenheid een winst te behalen, die de actiën weder rijzen deed en haar bestuurders met nieuwen ondernemingsgeest bezielde. '

Hoeveel "eclat," om met de Heeren Zeventien te spreken, het gebeurde "door geheel Europa geven» mocht, "tot schande van zulke onwaardige Compagniesdienaren» als die De Apollo hadden laten doorglippen; en "tot groot encouragement van andere diergelijke avonturiers en irreparabele schade van de Compagnie, ${ }^{2}$ het succes van de Ostendenaars bleek bij slot van rekening slechts de laatste opflikkering te zijn geweest als het ware van een die ten doode is opgeschreven. Den 20 Februari 1732 , te nauwernood vijf maanden na de terugkomst van De Apollo, voldeed de Republiek aan 's Keizers lievelingswensch door het garandeeren van de Pragmatieke Sanctie, die aan zijn dochter Maria Theresia de troonsopvolging in zijn erflanden verzekerde, en waarbij de Keizer zich van zijn kant verbond om aanstonds en voor altijd te doen ophouden allen handel van uit de Oostenrijksche Nederlanden op Oost-Indië en vice-versa.

Zoo onze diplomatie door het tractaat van 20 Februari 1732 de gevaren afwendde, welke de Compagnie van uit de haven van Ostende bedreigden, dat zij haar strijd tegen vreemde mededinging straks op een ander front zou moeten overbrengen, beseften de Bewindhebbers volkomen. Het behaalde succes kon hun niet verhelen dat de verboden boom van den Oost-Indischen

1 Huisman, a. w. p. $494,495$.

2 Brieven van de XVII aan GG, en RR. 9 Oct. en 22 Nov, 1731. 
handel zijn wortelen had geschoten door geheel Europa, niet alleen in het westen waar de Portugeezen en Spanjaarden naar luid van de geruchten ook al sterker dan vroeger op Oost-Indië dachten te varen, ${ }^{1}$ maar vooral in het noorden, met name in Zweden, ${ }^{2}$ waar een vereeniging van kooplieden met zekeren Hendrik König aan het hoofd op 14 Juni 1731 van koning Frederik I octrooi had verkregen voor een compagnie, die gedurende de eerstvolgende vijftien jaren gerechtigd zou wezen om met uitsluiting van alle andere onderdanen der Zweedsche Kroon handel te drijven op Indië. ${ }^{3}$ Wij begrijpen welke gevoelens de stichting van deze maatschappij hier te lande opwekken moest, toen men er ongeveer een maand later door een mededeeling van den Zweedschen gezant aan de StatenGeneraal ambtelijk van werd verwittigd. ${ }^{4}$ Wat beteekende het dat de koning haar uitdrukkelijk de vaart verbood op al die plaatsen, waar andere vreemde natiën bereids hun gezag en handelsetablissementen hadden gevestigd? Immers ook zonder een diergelijk bedrijf - te vermetel trouwens om in eenig redelijk Zweedsch brein op te komen - vermochten König en de zijnen onze Oost-Indische Compagnie al ernstig genoeg te benadeelen. Zoo verschafte hun onderneming, om maar iets te noemen, al dadelijk gelegenheid tot plaatsing en emplooi aan de kapitalen en dienaren der ten doode gedoemde Compagnie van Ostende. ${ }^{5}$

1 Blijkens een brief van den Consul Heisterman te Lissabon (aan den griffier der Staten-Generaal?) van 16 Oct. 1731 was daar kort te voren bij een plakaat bekend gemaakt, dat koning Johan V aan een Portugeesch koopman vergunning had geschonken om zijn schip in Februari 1732 naar Soeratte en de kust van Coromandel te laten afgaan ten einde daar handel te drijven, en had bedoelde koopman met eenige anderen daar een soort van compagnie voor geformeerd, op welke een ieder tot 29 Oct. 1731 mocht inschrijven. Wat Spanje betreft, zoo verleende koning Philips V op 29 Maart 1733 octrooi om te Cadix een nieuwe compagnie op te richten voor den handel op de Philippijnen en Oost-Indië (zie Dumont, Corps diplomatique, Supplément, Tome II, Partie I p. 418) doch volgens Bonassieux, Les grandes compagnies de commerce, Paris 1892 , p. 450 , zou de oprichting geen voortgang hebben gehad en het plan eerst omstreeks 1784 weer zijn opgevat.

? Brief van den Eersten advocaat der Nederl. O. I. Compagnie Abraham Westerveen aan Sir Matthew Decker 20 Nov. 1731.

3 Een Fransche vertaling van het octrooi bij Dumont, a. w., Supplément, Tome II, Partie I p. 503.

4 Resol. Staten-Generaal 18 Juli 1731.

${ }^{5}$ Inderdaad heeft de deelneming der Ostendenaren niet weinig aan het

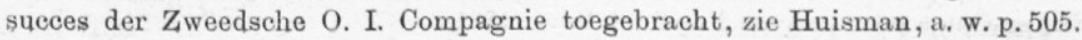


Want al wilde het octrooi aan het gansche werk een, althans in de hoofdzaak, zuiver Zweedsch karakter geven, uit verscheidene bepalingen was klaar te zien, hoezeer buitenlandsche deelneming even welkom was als die van de Zweden zelve. Een van de artikelen bijvoorbeeld kende de Compagnie het recht toe om in haar dienst te nemen alle daarvoor geschikte vreemdelingen, die zich in Zweden metterwoon kwamen vestigen. Dezen zouden voor hun persoon en goederen dezelfde voorrechten genieten als geboren $Z$ weden en zelfs, indien zij dit begeerden, brieven van naturalisatie kunnen bekomen. Verder werd verordend dat op de gelden, door vreemdelingen of anderen in de Compagnie ingebracht, nimmer beslag mocht worden gelegd door wien of onder wat voorwendsel ook. En voor het geval in de staten, waar de vreemde liefhebbers woonden, alle deelneming in buitenlandsche compagnieën bij de landsplakaten strafbaar was gesteld, kwam het octrooi aan hun bezwaren te gemoet door het voorschrift, dat de directeuren op straffe van schorsing de namen der actiehouders mitsgaders het bedrag hunner inschrijvingen geheim moesten houden, en aan niemand inzage mochten verstrekken van de boeken. Wie stond er borg voor dat de winzucht ook van onze eigen vaderlandsche financiers tegen de verzoeking om Zweedsche actiën aan te koopen bestand zou zijn? Een tweede vraag, die de gemoederen verontrustte, betrof de veilingen van König's Compagnie. Zeker, het octrooi gebood dat die te Gothenburg moesten geschieden, doch tegelijkertijd gaf het den koopers verlof om tegen betaling van een uiterst geringe recognitie de gekochte goederen desverkiezende rechtstreeks naar buitenslands te laten vervoeren. Hò licht kon dit tengevolge hebben dat men de Indische waren, na ze voor den vorm te Gothenberg te hebben geveild, metterdaad op de een of andere plaats in den vreemde ter markt bracht, en wat plaats was hier beter voor gelegen en geschikter toe dan Hamburg? Daar kwam nog bij dat König in de Elvestad persoonlijke relatiën bezat, welke zijn streven in de hand konden werken: hij had er namelijk een broeder wonen, die door zijn huwelijk was vermaagschapt aan de aanzienlijkste regenten en kooplieden. ${ }^{1}$ En juist naar

1 Brief van onzen resident Mauricius te Hamburg aan den griffier der Staten-Generaal François Fagel 14 Sept. 1731. 
Hamburg werd gelijk wij weten door allen, die bij de Engelsche of Nederlandsche Oost-Indische Compagnie betrokken waren, in dit tijdsgewricht met groote bezorgdheid de blik gewend. ${ }^{1}$

Natuurlijk was de Zweedsche en in het algemeen elke andere onderneming van denzelfden aard het best te stuiten wanneer, overeenkomstig een van Engelsche zijde opgeworpen denkbeeld, Groot-Brittannië te zamen met Frankrijk en de Republiek aan gene zijde van de Kaap alle schepen lieten nemen van die natiën, "die niet sedert een geruimen tijd van jaren in possessie waren van de Indiën te bevaren», onverschillig met welke passen zij voeren. ${ }^{2}$ Evenwel, hoe ijverig zij overigens de Oost-Indische Compagnie door hun diplomatie de hand boven het hoofd hielden, zulk een maatregel vonden onze staatslieden toch al te kras. Men betwijfelde zeer, zoo gaven de Staten-Generaal aan onzen gezant te Londen te kennen, "of dit middel bestaan kon met het algemeene recht, , in elk geval, zeiden zij, "zou het zekerlijk subject wezen aan zeer zware gevolgen. ${ }^{3} \mathrm{Zij}$ bepaalden er zich derhalve toe een plakaat uit te vaardigen, waarbij aan de ingezetenen onder bedreiging van zware geldboeten werd verbóden op eenigerlei wijze deel te nemen in compagnieën en ondernemingen, welke men buitenslands voor den Oost-Indischen handel mocht oprichten, hetzij door het inleggen van kapitaal of door persoonlijke dienstneming of ook door het sluiten van assurantiën op hun schepen en ladingen of het verstrekken van geld op bodemerij. ${ }^{4}$ Werd zoodoende het "algemeene recht door hen ongekrenkt gelaten, dat de Staten-Generaal zich niet in het minst bekreunden om de ongeschreven wetten der humaniteit bewijst hun beslissing op het verzoek van den Zweedschen gezant te 's Hage dat wij de Zweedsche Oostinjevaarders, als zij wegens stormweer of gebrek aan drinkwater aan de Kaap of elders bezuiden den Evenaar binnen vielen, dezelfde hulp zouden gelieven te betoonèn, die er onder zulke omstandigheden door andere natiën werd

1 Zie hiervóór blz. 60, 61.

2 Brief van onzen gezant Hop te Londen (aan den griffier van de StatenGeneraal?) 12 Febr. 1732.

3 Secreete resol. Staten-Generaal 25 Febr. 1732.

4 Plakaat van de Staten-Generaal 24 Sept. 1732, Groot Plakaatboek VI blz. 266. 
genoten. ${ }^{1}$ Mocht de gezant, zoo leest men in hun besluit van 22 December 1731 , nader om antwoord aanhouden, dan zal hem worden medegedeeld "dat zijne Majesteit de Koning van Zweden niet kan ignoreeren, dat de nieuwe Oost-Indische Compagnie in Zweden opgericht niet anders kan als schade toebrengen aan de geoctroyeerde Oost-Indische Compagnie dezer landen, en dat daarom niet gevergd kan worden van haar Hoog Mogenden, hoe genegen die ook zijn om aan zijner Majesteits onderdanen alle assistentie té bewijzen, de voorschreven Compagnie in eenigerhande wijze te favoriseeren.»?

Nog minder welwillendheid hadden titteraard de Zweden te verwachten van de autoriteiten onzer Oost-Indische Compagnie: in hun brief van Maart 1732 gaven de Zeventien aan de Hooge Regeering te Batavia order, dat zij al de onder haar bewind staande gouverneurs en verdere gezaghebbers tot de scheepsoverheden incluis wel scherpelijk verbieden zou de Zweedsche schepen "aan of beoosten de Kaap eenige de minste geriefelijkheid van vivres, eet- of drinkwaren, equipagegoederen, water, brandhout of wat het ook zoude mogen wezen, aan eenige reeden, havens of aan land toe te staan of uit de schepen op zee over te geven, alsmede niet aan de schepen van Denemarken gaande of komende van of naar China of eenige andere plaatse, daar de Denen voor dezen niet gewoon zijn geweest te varen, exempt die gaan of komen van Trankebar of eenige andere van ouds gestabilieerde comptoiren van laatstgemelde natie, hetwelk (merkten zij in hun brief op) men altoos onder pretext van eigen behoefte of gebrek wel kon excuseeren ${ }^{3}$ - een bevel, dat door de Hooge Regeering niet alleen gereedelijk werd opgevolgd maar zelfs nog verscherpt door aan elk vertrekkend schip een lastbrief mede te geven, die den gezagvoerders "op poene van hare hoogste indignatie» voorschreef aan $Z$ weedsche of Deensche bodems bij ontmoeting geenerlei gerief of bescher-

1 Resol. Staten-Generaal 31 Oct. 1731.

2 Secreete resol. Staten-Generaal 22 Dec. 1731.

${ }^{3}$ Brief XVII aan GG. en RR. 4 Maart 1732. De Nederlandsche Compagnie volgde in dezen slechts het voorbeeld van haar Engelsche zuster, want blijkens een brief van onzen gezant Hop te Londen aan den griffier der Staten-Generaal van 19 Febr. 1732 had die insgelijks aan hare bedienden in Oost-Indië verboden de aldaar komende Zweedsche schepen te assisteeren met eenige ververschingen of andere behoeften die zij zouden vragen. 
ming te verstrekken noch in correspondentie met hen te treden, maar dat zij integendeel zulke bodems, voor zooveel die de onzen geen "reden van offensie" mochten geven, op de allerindifferentste wijze zouden hebben aan te zien als schepen, voor dewelke men geen de minste complaisance of inschikkelijkheid hebben zou.»' Intusschen leed het ernstige twijfel of met een dergelijk optreden veel te bereiken viel. Op een gebied toch zoo wijduitgestrekt als dat van den Indischen oceaan waren plaatsen in overvloed, waar een ieder voor geld en goede woorden zijn gerief kon vinden van al wat hij behoefde, en bijgevolg zou het verbod'alleen dan iets baten wanneer buitengewone ongevallen, die men vooraf niet bepalen noch berekenen kon, de Zweden c.s. noodzaakten in een Compagnieshaven binnen te vallen, doch voor de rest al van even weinig uitwerking wezen als voorheen met de Ostendenaren was ondervonden, die nadat een gelijk verbod tegen hen was uitgevaardigd daar echter de Indische zeeën niet minder om hadden bevaren dan te voren. ${ }^{2}$

Aldus begreep het de Hooge Regeering te Batavia en de vraag is gewettigd, of ook de Bewindhebbers zelf van zulk een optreden wel veel heil hebben verwacht. Zij waren er althans ernstig op bedacht nog andere pijlen op hun boog te nemen. Zoo kwam het bij dat in de Vergadering der Zeventien van Maart 1732 een aantal middelen werden voorgesteld die, naar men zich beloofde, de vaart uit het Noorden naar OostIndië "zoo niet geheel beletten tenminste in verscheidene opzichten difficiel» zouden maken. In de eerste plaats werd genoemd "het tijdig opkoopen der recepissen om de Mexicanen, ducatons en pilaren vroegtijdig meester te worden en al zoodanig muntmateriaal als tot den Indischen handel vereischt werd, dat zoo men vermeende met een som van 50 à 60 duizend gulden jaarlijks te doen was en de Compagnie een vaste winst zou toebrengen, "alzoo de differentie van prijs in een rond jaar per mark doorgaans wel kwam te differeeren of te rijzen van zeven tot veertien stuivers en de equipagie der competiteuren, die haar contanten meest van hier moesten hebben, difficiel ten minste kostbaarder zoude maken, vooral indien men bij

1 Van der Chijs, Nederlandsch-Indisch Plakaatboek, IV blz. 306.

2 Resol. GG. en RR. 9 Maart 1733. 
den Staat ook kon te weeg brengen dat er op de respective munten der Vereenigde Provinciën geen ducatons voor particulieren meer mochten geslagen worden, maar dat de ducaton voortaan alleen wierd gemaakt en gehouden tot een penning van negotie voor Indie.» Voorts meenden de voorstellers dat men, om de Zweden en Denen en de anderen uit het Noorden den voet dwars te zetten, "de koopmanschappen ter kuste daar zij aankwamen, hetzij in Bengalen, Coromandel of elders, zooveel doenlijk vóór dien tijd moest opkoopen, en daarin de concert gaan met de Engelschen, al was het dat men in zulken gevalle genoodzaakt was meer te koopen als er bij eisch gepetitioneerd was, ${ }^{1}$ dewijl wel apparent was dat de Bewindhebbers in Engeland geen zwarigheid zouden maken om hare bediendens in Indië mede te dien fine te gelasten." En "on 'zulks ook in China werkstellig te maken ten minste tot zooverre dat de Compagnie altijd beter waar zoude kunnen koopen en de negotie met meer avantage doen als andere naties, hielden zij het voor raadzaam te Canton een comptoir op te richten, onderhoorig gelijk alle andere Indische comptoiren aan de Hooge Regeering te Batavia. Immers langs dien weg zou men "hoe langer hoe meer in de kennisse van der Chineezen handel en koopmanschap kunnen penetreeren, vele Vaderlandsche en Indische waren debiteeren, den voorkoop van de fijnste soorten van thee tijdiglijk doen, de porceleinen naar de sierlijkste modellen doen bakken, het varend volk veel beter onder discipline houden. en meer in staat wezen om van de vreemde natiën den voorrang te hebben.» Doch om dat oogmerk des te beter te bereiken behoorde huns inziens aan Gouverneur-Generaal en Raden vooraf te worden gevraagd shoe het haar zoude voorkomen, indien men jaarlijks drie à vier hetzij meerder of minder schepen van Batavia met specerijen, peper, sappanhout en andere waren, die de Chineezen nu gewoon waren (met hun jonken) van daar af te halen, naar China kwam te zenden en die beladen met thee, porceleinen en verdere Chineesche waren weder naar Batavia te doen retourneeren, te weten zooveel en niet meer als men voor de Bataviasche consumptie van noode had alsmede voor de kisten van het repatrieerend volk, zonder dat men in dien gevalle eenige Chineezen of Portugeezen te Batavia

1 De „eisch" of bestelling van al wat uit Indië aan koopwaren enz. door de Bewindhebbers werd ontboden. 
zou permitteeren om thee aan de Compagnie of particulieren te verkoopen ten minste niet boven een scheepslading, latende haar het debiet van andere koopmanschappen vrij en onverhinderd gelijk dat tot dusverre gedaan was. M Men zou verder het comptoir te Canton kunnen gelasten een onderhoorig comptoir mede op Amoy aan te leggen als dat dienstig werd geoordeeld cen de versche thee en nieuwgebakken porceleinen, die voor het Vaderland gerequireerd werden, direct met twee à drie schepen herwáarts aan de respective Kameren te laten afgaan, zonder dat alsdan van noode zoude zijn om van hier direct naar China te equipeeren; men zou hierdoor onder andere ook kunnen teweeg brengen dat de thee voor het Vaderland ordentelijk in kisten wierd afgepakt om de scheepsruimte en inzonderheid de tarra bij verkoop, die nu zeer groot en irregulier was door de menigvuldige differentie van fustage, te menageeren en uit te winnen, dat dan ook strekken zoude tot beter conservatie van de bladeren in het overbrengen en tot securiteit voor de schepen tegens de zeeroovers mitsgaders tot vermijdinge van een vruchtelooze heenreis, die de schepen nu moesten doen tenminste tot op de hoogte van Straat Soenda, zonder iets ten dienste der Indische comptoiren te kunnen medenemen of afleveren, moetende bovendien ook met gereed geld gekocht worden hetgeen men anderszins voor koopmanschappen zoude kunnen inhandelen of troqueeren. ${ }^{1}$ De legdagen der schepen in China konden naar gissing (zoo vervolgen de voorstellers) ook wel twee maanden korter wezen en de retourneerende schepen vroeger in Europa aankomen als andere natiën, die daar moeten blijven vertoeven totdat alles wordt gereed gemaakt en genoegzaam op één tijd alles tegelijk inkoopen, dat de prijzen zeer doet steigeren en de onkosten vermenigvuldigen, die in sommige opzichten voor de Compagnie, als er een permanent comptoir was, nog apparentelijk wel zouden kunnen verminderd worden zoo ten regarde van de maandgelden ${ }^{2}$ als de tollen en ongemeene spendatiën, die de scheepsoverheden gedurende haar verblijf in China althans ${ }^{3}$ genecessiteerd zijn te doen. Ook zou het aanbrengen van particuliere kooigoederen (meenden zij) zoo van Batavia als China zelf veel worden belet, bijaldien het varend volk in China onder

1 Inruilen, Portugeesch: trocar.

2 Maandelijksche gages.

s Tegenwoordig. 
bedwang der bedienden van het comptoir zoude staan, die nu altijd occasie hebben om te deserteeren, haar ordinaire scheepsoverheden niet veel estimeeren en somtijds al vrij wat den - meester beginnen te spelen, daar men ter contrarie als er een permanent comptoir was veel zoude kunnen doen met die van andere natiën zelve over te nemen en naar Batavia te verzenden, waardoor derzelver schepen in haar terugreize naar Europa somtijds zouden kunnen verhinderd of gefrusteerd worden. En bijaldien tot Batavia geen meer thee of porcelein zou mogen inkomen als de Compagnie direct uit China met hare eigene schepen laat aankomen, zou men eindelijk (zeggen zij) ook eens het groote oogmerk kunnen bereiken, dat er zoo menigte van particuliere thee, die jaarlijks op twintig à vijf-en-twintig honderdduizend pond begroot wordt, met de excessieve kooien en bultzakken niet wierd ingebracht en de schepen daarmede zoo zeer overladen wierden, als men van tijd tot tijd naarmate dat de thee abondanter en beterkoop wordt meer en meer ziet toenemen, zonder dat er tot nog toe eenig middel of resolutie van succes is geweest om hetzelve te beletten.» Eindelijk zouden (hun erachtens) gelijk hiervoren met een woord was aangeroerd de reizen "ook secuurder zijn tegen den aanval van roovers, welke onverlaten (zeggen zij) in macht toenemen en ter occasie dat zich althans zoo veel lorredraaierij en kwalijk gearmeerde schepen met goede geldsommen uit het Noorden en elders in het vaarwater zullen laten zien, die op zekere tijden van het jaar zoo gaande als komende lichtelijk kunnen geattrappeerd worden, meer en meer aangroeien tot zulk een getal als men in vorige tijden heeft gezien, dat de roover Cangi Angria met veertig schepen of vaartuigen in zee heeft kunnen komen, ${ }^{1}$ buiten de roovers van Madagaskar, waaronder zich in zoo eenen tijd allerlei slag van natiën als Engelschen, Hollanders, Portugeezen en anderen zich begeven, die de zee zeer onveilig maken. Want men zoude 's Compagnie's schepen altijd welvoorzien en gecombineerd met den anderen kunnen laten varen, latende andere natiën, die dat vermogen niet hebben, zorg dragen voor haar eigen securiteit. Ten welken opzichte (door de voorstellers) ook niet dienstig geoordeeld werd de Indische Regeering gelijk voor dezen

1 Blijkens resol. Gourerneur-Generaal en Raden van 10 Sept. 1708 een befaamd zeeschuimer op de kust van Malahaar. 
heel veel te animeeren om kostbare equipagiën te doen tot extinctie van dat roofgespuis.» Evenwel, «hetzij de Vergadering van Zeventien mocht kunnen goedvinden in het sentiment over te gaan om dusdanig comptoir in China op te richten of niet in allen gevalle waren de voorstellers van gevoelen dat men nog dit jaar en vervolgens met de directe vaart naar China behoorde te continueeren, totdat men de gedachten van Gouverneur-Generaal en Raden op dit subject had vernomen en de noodige orders tot Batavia en in China zouden gesteld zijn om in geen gebrek van thee te vervallen, waardoor de buitenlandsche natiën in plaats van gediscourageerd nog meer zouden geanimeerd worden door de groote winsten, die zij in zoodanigen gevalle, als er een interruptie kwam zóó dat minder thee door de Compagnie wierd aangebracht, zouden behalen.»'

Aan de mededingers den inkoop af te snijden van het met name voor den Chinaschen handel onontbeerlijke muntmateriaal; zich op de kust van Coromandel, in Bengalen en elders vooraf van de door hen begeerde koopwaren meester te maken; in Canton, zoo noodig ook te Amoy, een vast comptoir te stichten om hun met het inslaan van thee, porcelein en wat China al meer voor de Europeesche markt uitleverde, vóór te kunnen zijn en tevens hun scheepsvolk tot desertie en dienstneming op Compagnie's bodems te verlokken, zoodat hun terugreis vertraagd misschien zelfs geheel onmogelijk werd gemaakt, inderdaad het was een grootsch ontwerp, dat de Heeren Zeventien voor oogen zweefde. Bleek het uitvoerbaar zoo mochten zij indien al niet de volkomen onderdrukking er zich voor het minst een allergeduchtste verzwakking van de Oost-Indische negotie der Zweden c. s. van beloven, gezwegen nog van de andere voordeelen die het der Compagnie kon toebrengen. Doch juist aan de uitvoerbaarheid schortte het. Althans de Hooge Indische Regeeting, aan wie door de Zeventien om voorlichting werd gevraagd, ${ }^{2}$ opperde gewichtige bedenkingen op dit punt. ${ }^{3}$ Wanneer de Compagnie te Amsterdam en op de andere plaatsen, waar hare mededingers zich doorgaans van die waar kwamen voorzien, vooraf de courante muntspeciën opkocht, zou hun daarmede zeer zeker de voet dwars gezet en hun winst eenigszins ver-

1 Resol. XVII 4 Maart 1732.

$2 \mathrm{Als}$ voren.

s Het advies van GG. en RR. is ingelaseht in hun resolutie van 9 Maart 1733. Dl. 73 
minderd worden, de Bataviasche regeering erkende het volmondig, maar dat men hun zoodoende eenig wezenlijk nadeel kon berokkenen betwijfelde zij ten sterkste. Bij ontstentenis toch van gemunt zilver stond hun nog altoos de weg open om zich te Cadix of elders ongemunt zilver te verschaffen, dat genoegzaam hetzelfde was dewijl baar zilver in Indië weinig minder rendeerde dan ducatons of andere gemunte speciën, en de Chineezen deze niet zochten om de wille van de munt maar om het metaal, waarvan zij geslagen waren, en omdat zij aan het laatste gebrek hadden. Buitendien waren de Chineesche kooplui nu van het gehalte der speciën zelf alreeds zoo goed op de hoogte en wisten zij daar den prijs zoo wel naar te regelen dat men zelfs het Nederlandsche "payement, , hoezeer zij daar overigens ook op gesteld waren en hoe geriefelijk ook als pasmunt, ${ }^{1}$ te Batavia nooit tot dien prijs had zien stijgen "als op ducatons of ander deugdzaam zilver geprofiteerd werd " om reden de dubbeltjes zoowel als de schellingen van "een minder allooi» waren. En dat een ieder, die dat wenschte, baar zilver verkrijgen kon, was in 1731 aan het licht gekomen toen de Zweden voor de Fridericus Rex Sueciæ de benoodigde hoeveelheid te Cadix hadden ingekocht. ${ }^{2}$ Door het een en het ander kwam tegelijk het voorstel van de Zeventien te vervallen omtrent de aanmunting van den ducaton uitsluitend voor het gebruik in Indië, meenden Gouverneur en Raden. Immers zoo bij Chineezen als Mooren waren andere speciën, indien hun gehalte maar even goed was als dat der ducatons, niet minder in trek dan deze laatste vermits zij ook in het gebied van den Groot-Mogol alle zonder onderscheid tot niets anders werden gebezigd dan om ze in de munthuizen van Soeratte, Bengalen en Coromandel tot zilveren ropijen te verstempelen. In Bengalen en elders van Compagnie's wege vooraf de koopmanschappen op te koopen om de markt voor de Zweden c.s. geheel te ontblooten, gelijk de Zeventien in bedenken gaven, leek de Indische Regeering "wel moraliter impossibel» toe, ten minste voor zooveel Bengalen, Coromandel en de lijnwaadgevende comptoiren in het rijk van den Groot-Mogol betrof. Want de lijnwaden, zoo merkte zij op, plachten daar te lande

1 In het oorspronkelijke staat: „en hoe geriefelijk het is om den gemeenen man van den anderen te helpen."

2 De Fredericus Rex Sueciae, het eerste voor Oost-Indië bestemde schip van de Zweedsche Compagnie, zeilde nit in 1731 . 
uithoofde van de armoede der wevers zoo goed als niet op voorraad te worden gemaakt - de weinige, waarmede dit geschiedde, dienden meest voor inlandsch verbruik en kwamen dus voor geen uitvoer in aanmerking - maar op contracten van aanbesteding, gesloten met voorname kooplieden door wie de leverantie van de overeengekomen partijen ter bezorging werd overgegeven aan "mindere factors, " die zich dan op hunne beurt door geldelijke voorschotten van zooveel weefgetouwen wisten te verzekeren als tot voldoening van de contracten noodig waren. Bijgevolg was een ieder, die met geld voor voorschotten ter markt kwam, tot het doen van zulke aanbestedingen even na, of was het, op zijn minst genomen, ondoenlijk "gemaakt goed op te koopen en vreemde handelaars daarin te verkloeken. $v$ Daarenboven was er, met het oog op de uitgestrektheid dier landen en het overgroot getal van wevers en weefgetouwen geen denken aan die alle voor de Compagnie in beslag te nemen, eensdeels omdat de kooplieden ook zelf alom verspreid waren en die van de Engelsche en Nederlandsche Compagnieën nog maar een gedeelte van den grooten hoop uitmaakten, en anderdeels omdat men de kooplieden, op zich zelf niet vermogend genoeg om met eigen kapitaal "zulk een considerabelen ommeslag gaande te houden," gewis met voorschotten op de leverantiën zou moeten bijspringen en zich zoodoende "vast maken" of althans bloot stellen zou aan menigvuldige bankroeten, wier bedragen schier "niet te limiteeren" waren. Ook zou de verre afstand van vele weefplaatsen van de Engelsche en Nederlandsche Compagniescomptoiren niet alleen de inzameling der aanbestede fabrikaten zeer bemoeilijken maar tevens hun afvoer hoogst periculeus maken "door de vexatiën der Mooren inzonderheid bij eenige revolutie in haar regeeringe, s gelijk de ondervinding voorheen had geleerd, gezwegen van de zware vervoerkosten, zelfs al liep men bij het transport zelf geen groot gevaar, die de goederen zoo wegens de vele tollen als andere ongelden zoo hoog op stok zouden doen loopen, dat er onmogelijk eenige winst meer op te behalen viel, en daargelaten nog de vele bedriegerijen, aan welke men bij de inzameling van de zijde der landzaten met hun bekenden trouweloozen aard zou blootstaan. Voorts waren diergelijke "wijdverspreide en geëxtendeerde aanbestedingen natuurlijk niet te doen zonder dat de mededingers of hun handlangers daar al mede hun rol onder konden 
spelen, als brakken die het wild voor hen opjoegen, waardoor de prijzen dermate zouden worden opgedreven dat de inlanders, na die voor het tegenwoordige onder allerlei voorwendsels te hebben verhoogd, naderhand van geen vermindering meer zouden willen hooren, - en men kon beseffen tot wat ongemeene schade dit der Compagnie zou gedijen. Daar kwam bij dat er om in Bengalen alles meester te worden wat dat land uitleverde groote spendatiën aan de overheden zouden noodig wezen. En waar zouden de benoodigde gelden en scheepsruimte van daan komen? In tijden toch, wanneer zij niet door oorlog, gebrek aan levensmiddelen, schaarschte van katoen of dergelijke rampen werden geteisterd, konden die landen, wanneer men de bevolking van alle kanten werk mocht willen geven ten einde te voorkomen dat zich anderen van de ledigstaande weefgetouwen bedienden, zulk een onnoemelijke hoeveelheid doeken uitleveren, dat die alleen voor rekening van Coromandel wel een uitgaaf zou vorderen van over de tien millioen, welke geheel in goud moest worden betaald en den tegenwoordigen ommeslag der Compagnie in die kwartieren verre te boven ging. Of het moest zijn dat de Zeventien aan Gouverneur-Generaal en Raden machtiging wilden geven om "door heimelijke correspondentie op de plaatsen, daar de vreemde trafiquanten haar aanbesteding deden, haar het goed vóór de leverantie af handig te maken door eenige spendatiën omtrent de kooplieden en eenige verhooging boven den bedongen prijs, zijnde dit het eenige middel waarmede mogelijk nog iets zou zijn uit te richten, inzonderheid op Coromandel, welks bevolking van zóó trouweloozen aard was dat zij voor geld tot alles kon gebracht worden en, in weerwil van de aangegane contracten, ter wille van de hoogere prijzen haar lastgevers wel zoude laten zitten en het goed aan de Compagnie overdoen, maar dan zou men zonder op geld te zien de weefsels zooveel duurder moeten betalen en niet letten op hun sortiment, lengte of deugdelijkheid. Voor het transport evenwel van zulk een onmetelijken voorraad van doeken zou de gansche handelsvloot, die de Compagnie in Indië in de vaart had, ter nauwernood toereikende zijn. Al even ongunstig oordeelde de Bataviasche regeering over het denkbeeld om in al deze dingen samen te gaan met de Engelschen in Oost-Indië. Haars inziens viel op de verwachting van de Zeventien, dat dezen van hun meesters in Europa gewisselijk tot zoodanige 
samenwerking met de onzen zouden gemachtigd worden, weinig te bouwen. Hoe menigmaal had men in dit opzicht een geheel andere ervaring opgedaan! Zoo hadden zij bijvoorbeeld in het vorige jaar hun "bezetting aan den Ganges ingetrokken, niettegenstaande de Nederlandsche Compagniesdienaren er tegen geweest en zelfs na hun vertrek aldaar gebleven waren. Buiten dat was een dergelijke samenwerking met de Engelschen volstrekt onuitvoerbaar ten aanzien van de lijnwaden, wijl bij het vertieren van deze koopmanschap door gansch Indië hun particulier belang ruim zoo veel was betrokken als dat van hun meesters, dat is de Engelsche Oost-Indische Compagnie zelve. ${ }^{1} \mathrm{Om}$ het voorgeslagen plan te verwezenlijken zou men derhalve met schier even zoovele handelssocieteiten en -societeitjes moeten overeenkomen als er Engelsche comptoiren waren of gegoede Engelsche Compagniesbeambten overmits zij de hun vrij gelaten particuliere vaart allerwege uitbreidden, zoodat zij de grootste mededingers van de Nederlandsche Compagnie waren ja mogelijk de eersten zouden zijn, die uit zucht naar eigen gewin met de Zweden en andere vreemdelingen één lijn trekken en hun langs indirecte wegen uit hun voorraad gerieven zouden. De vestiging van een comptoir of residentie in China ten einde gelegenheid te hebben om door den opkoop van de Chineesche waren de concurrenten ook daar te lande te verkloeken - een ander denkbeeld van de Heeren in Patria - trof naar de meening van GouverneurGeneraal en Raden evenmin doel. Ook China toch was een rijk, waarvan het binnenkomen aan een iegelijk vrijstond en trouwens ook niet wel te beletten was. Wij zouden zoodoende onze mededingers maar wakker maken ja hen aanmoedigen om daar op ons voetspoor insgelijks comptoiren te vestigen, dat hun voor hun spendatiën al zoo wel zou worden toegestaan als aan ons. Zoodat, na de fraaie sommen aan kosten van ambassades, geschenken en wat dies meer zij voor de oprichting van een comptoir besteed, het per slot van rekening met Compagnie's negotie in die streken nog zorgelijker en slimmer zou gelegen

1 Vgl. J. P. van Braam, Aanmerkingen en ophelderingen omtrent de particuliere navigatie en commercie die er in de Oost-Indiën geweest is en nog is (1790): „De Engelsche Oost-Indische Compagnie drijft geen handel van Indië tot Indië dan in zooverre eigen benoodigdheid betreft, al het andere aan particulieren overlatende". Met handel van Indië tot Indië wordt bedoeld binnenlandsche handel in Indië in tegenstelling van dien tusschen Europa en Indië, 
zijn dan te voren. Zeker, als de Compagnie te Canton een comptoir oprichtte, zouden haar bedienden hoe langer hoe meer in de kennis van den Chineeschen handel toenemen niet alleen maar tevens in den stillen tijd de vereischte aanbestedingen kunnen doen voor de leverantiën van de fijnste soorten van thee en de fraaiste en nieuwste modellen van porcelein, doch men. mocht vragen of de Engelschen, Franschen en andere Europeanen dit voorbeeld niet aanstonds zouden navolgen en of het, wanneer die op gelijken voet werden behandeld als wij, de Compagnie alsdan niet nog veel erger zou vergaan. Want gingen alle Europeesche natiën zich te Canton nestelen en toeleg maken om meester te worden van de Chineesche koopmanschappen, zoo ontstond er gevaar dat er niet genoeg overbleef voor de jonken, die uit den na het vertrek der Europeesche schepen overschietenden voorraad hun gading plachten te vinden maar in dat geval bij gebrek aan lading hun vaart op Batavia zouden moeten afbreken of verminderen. Zooals de zaken thans stonden opende hun komst te Batavia voor onze handelsartikelen een uitweg, waarbij der Compagnie als van zelf schier de geheele winst in den schoot viel die op hun uitvoer naar China werd behaald, vermits de Chineezen "zich op een gansch sobere wijze met hare vaart behelpende ook met een zeer klein winstje op den vervoer der meeste goederen van (Batavia) naar China tevreden waren en bijna zooveel bij de Compagnie besteedden als zij. in haar land daarvan weder te wachten hadden.» Hoe kon dit geringe verschil in den op Canton te maken prijs voor de Compagnie opwegen tegen de kosten van een comptoir en de bezwaren, welke zij zich op den hals zou halen, wanneer zij haar koopmanschappen, in plaats van die op den veiligen voet van tegenwoordig te Batavia aan de jonken te vertieren, "onder de geweldenarijen van een vreemde natie ging "hazardeeren, die ongetwijfeld met gedurige giften en gaven gepaaid zou moeten worden en naar alle gedachten ons veel lastiger vallen zou dan hare thans naar en van Batavia aan- en afvarende landslieden. Ook was in vroeger tijd, toen het Chineesche rijk nog veel minder van de Europeanen bevaren werd, genoeg gebleken hoe weinig profijt met de oprichting van comptoiren voor de Compagnie aldaar viel te behalen. Het was waar, de sinds eenige jaren zeer toegenomen vaart van allerlei natiën naar China scheen wel te bewijzen, dat de Chineezen niẹt meer zoo afkeerig 
waren van de Europeanen als voorheen en dat de zaken voor ons nu ook eenigszins gunstiger stonden, maar diezelfde wijziging in hun gezindheid jegens de vreemdelingen was nu aan den anderen kant weer in zoover een nadeel voor de Compagnie als zij eveneens haren concurrenten ten goede kwam. En op eenige kans dat van alle Europeesche volken alleen wij in China tot den handel zouden worden toegelaten, bestond geen uitzicht hoegenaamd. Veeleer gaven de van Canton overkomende geruchten reden tot twijfel of het den Chineeschen machthebbers wel believen zou vaste comptoiren te vergunnen aan welke Europeesche natie ook. Immers wilden zij, naar men zeide, zelfs "niet als met moeite en op een clandestiene wijze permitteeren, dat van de eene of andere natie een enkel mensch tot het navolgende jaar in haar factorijen tot Canton overbleef, alschoon dezelve dan nog genoegzaam voor Chineezen passeerden en . de gedaante daarvan aannemen moesten. » Ja men had hooren vertellen dat de wantrouwende Chineezen tot hun eigen landgenooten toe, die bij de Europeanen als tolken of anderszins dienden, van tijd tot tijd uit Canton deden vertrekken, zoo dikwijls zij vermeenden dat zij te familiaar met elkander werden, gelijk zij het vorige jaar ook alle monniken en priesters het land hadden uitgejaagd. Eindelijk zou de vermindering of staking van de vaart der jonken naar Batavia - het onvermijdelijk gevolg zooals zij bereids opgemerkt hadden van den maatregel door de Zeventien voorgesteld - aan onze nu nog redelijk welvarende kolonie te dier plaatse een zoo zwaren slag toebrengen, dat alleen reeds uit dezen hoofde het vestigen van vaste comptoiren in China voor de Compagnie onraadzaam was. Op de vraag, hun door de Vergadering van Zeventien voorgelegd, hoe zij er over denken zouden indien men de artikelen, tot dusver door de jonken uit Batavia afgehaald, zooals specerijen, peper, sappanhout enz., voortaan van Compagnies wege zelf met een jaarlijksche bezending van drie à vier schepen naar China afzond en deze bodems weder naar Batavia liet terugkeeren met juist zooveel C'hineesche goederen als benoodigd waren voor het plaatselijk verbruik aldaar en voor de kisten van het repatrieerend volk, en indien men dan tegelijkertijd een verbod uitvaardigde dat de Chineezen en Macaosche Portugeezen te Batavia aan de Compagnie of particulieren geen thee meer mochțen verkoopen, althans niet boven een enkele scheepslading, 
terwijl hun de omzet van andere koopmanschappen zoo vrij en onverlet zou worden gelaten als te voren - op die vraag van de Zeventien antwoordden Gouverneur-Generaal en Raden in de hoofdzaak als volgt. Wat de Portugeezen betrof, nu toch meest maar op vracht varende voor de Chineezen en daarbij dermate verarmd dat zij zelfs werk hadden om het gaande te houden laat staan bij machte waren om tot den Chinaschen handel veel toe- of af te doen, vielen tegen zoodanig verbod geen groote bedenkingen in te brengen. Anders echter was het gelegen met de Chineesche jonkschippers. Die zouden zeer waarschijnlijk hun vaart niet goed kunnen maken als de aanbreng van de twee voornaamste artikelen hunner negotie, thee en porcelein, aan hen werd belet en alleen de sleet veroorloofd werd van eenige Chineesche snuisterijen van geringe waarde en te Batavia genoegzaam alleen te debiteeren onder hun eigen volk. De gevolgen konden niet uitblijven: stremming, kwijning en verval van de vaart der jonken met al de nadeelen hieraan voor de Compagnie en haar hoofdzetel onafscheidelijk verknocht. Dat wel is waar zulke vaste comptoiren te Canton en Amoy een meer eendere, beter bewarende en minder plaats innemende afpakking van de thee waarborgden gaven Gouverneur-Generaal en Raden gereedelijk toe. Ook de verwachting van de Zeventien dat de Compagnie, wanneer zij zelf direct van Batavia op China voer, de Chineesche retourgoederen niet langer met contanten zou behoeven te koopen maar kunnen inruilen tegen koopmanschappen, achtten zij geenszins ongegrond. Echter moest men niet denken dat zoodanige directe vaart in China een grooteren omzet zou medebrengen van de artikelen, thans door de jonken afgehaald, aangezien de schippers van deze vaartuigen op hun te Batavia ingeslagen lading niet heel veel meer wonnen dan de vracht en de ${ }^{\cdot}$ onkosten, ja ze zelfs, gelijk men te Batavia beweerde, meest weer tegen den inkoopsprijs van de hand deden, en ze meerendeels alleen hierom tegen die hooge markt opkochten omdat er altoos nog iets meer profijt op viel dan op contanten, die zij anders als retourwaar zouden moeten medenemen. Misschien mocht men eenige winst verwachten van de peper, edoch de vraag deed zich op of het voordeel wel de risico van deze negotie zou evenaren, om niet te spreken van de verliezen aan onderwichten en spillages welke die korrel bij vervoer te lijden had, zoodat het bij vestiging van 
een Compagniescomptoir te Canton voor ons nog maar altoos het beste zou wezen daar met gereed geld ter markt te komen of voor het minst slechts met zulke grove goederen als lood, tin, sappanhout, enz., die de schepen voor hun ballast toch niet konden missen en waarop geen noemenswaarde onderwichten of spillages vielen. Wijders betwijfelde de Hooge Regeering of wij met de opening van de rechtstreeksche vaart van Batavia naar China de ligdagen onzer schepen daar te lande konden bekorten, en insgelijks of een vast comptoir eenige vermindering mogelijk maakte van de maandgelden, spendatiën en andere lasten, waardoor de tegenwoordige vaart derwaarts van uit Nederland werd bezwaard. Voor het eene, merkte zij aan, bestonden maar twee middelen: ò vroeger van Batavia afzeilen òf vroeger uit China wederkeeren. Koos men het eerste, zoo was het volstrekt noodig dat wij ginder een comptoir bezaten met permanente bedienden, die er van te voren in tijds de vereischte partijen opkochten, opdat onze schepen daar bij aankomst dadelijk hun lading gereed vonden. In dit geval behoefden zij niet vóór half Juli, ja wellicht pas in het begin van Augustus, de Bataviasche reede te verlaten. Zonder het bezit van een comptoir evenwel waren zij genoodzaakt op den gewonen tijd, dat is in het laatste van Mei, zee te kiezen, wijl anders de Engelschen, Franschen en anderen tot onze schade eerst aan de markt zouden zijn. Wat den terugkeer uit China aanging, hierbij waren de schepen noodwendig gebonden aan het invallen van den noordermousson, die niet vóór het begin van December was te betrouwen. Op de gages ware bij de directe vaart van Batavia ongetwijfeld wel iets te bezuinigen omdat die met gewone beambten te doen zou wezen, terwijl de nu uit Europa afgezonden supercarga's door de Compagnie ten duurste moesten betaald worden. Doch hetgeen men zoodoende -uitwon zouden, als er een comptoir werd gevestigd, de lasten van hetzelve weer verslinden, indien die al niet de kosten van thans kwamen te overtreffen. Met de spendatiën zou het bij de directe vaart niet beter gaan, om het even of er te Canton een comptoir bestond of geen: men moest de grooten en regenten in China nu eenmaal de hand vullen, daar was geen ontkomen aan, en in het eerste geval, moest men vreezen, zouden deze plagerijen het gansche jaar door duren en dus nog veel hooger oploopen. Dat met de vestiging van zulk een vast 
comptoir het varend volk beter in den band zou zijn te houden, gelijk de Zeventien verwachtten, werd door Gouverneur en Raden erkend, doch niet dat men zoo doende het deserteeren zou kunnen voorkomen, de voorbeelden van het tegendeel in Bengalen en elders gezien bewezen hoe weinig het volk zich om de. Compagniesetablissementen placht te bekreunen, waar het onder diende. Evenmin zou langs dien weg het heimelijk vervoer van kooigoederen uit China naar Europa belet kunnen worden, veel minder nog dan op Batavia zelf waar het als onder de oogen van de Hooge Regeering, in spijt van alle maatregelen door haar genomen, maar steeds bleef doorgaan. Het beste middel om de desertie onzer schepelingen te keeren bestond blijkens de op verschillende plaatsen opgedane ervaring hierin, dat men die van andere natiën verleidde om tot ons over te loopen, wat men door verhooging van onze gages in de hand kon werken. Maar dit middel moest met groote omzichtigheid worden toegepast opdat de vreemden van hun kant niet bij wijze van réprésaille hetzelfde gingen doen met onze eigen zeevarenden, die ook niet heel vast in de schoenen stonden en zich, voor een goeden stuiver gelds al even gemakkelijk lieten omkoopen als de hunne. Op een andere vraag van de Zeventien, te weten of men te Batavia geen andere thee en porceleinen meer toelatende dan er door de Compagniesschepen derwaarts zouden worden aangebracht daarmede niet voor goed een eind kon maken aan den buitensporigen overvoer van thee door particulieren, gelijk deze thans van uit Batavia naar Nederland tegen alle plakaten en verboden in plaats had, luidde het antwoord van Generaal en Raden eveneens ongunstig. Het geneesmiddel ware huns inziens erger dan de kwaal zelve daar het, zooals zij vroeger reeds betoogd hadden, den doodsteek zou toebrengen aan de voor Batavia's bloei zoo onontbeerlijke vaart van de jonken, terwijl de Compagnie veeleer behoorde te handelen als een goed hovenier, die immers wegens een enkelen aangestoken tak geen ganschen boom omhakte. Zooveel stond vast, zonder geweld viel op geen bereiken van dat groote oogmerk te rekenen. Maar dit zou zulk een algemeen misnoegen verwekken, dat men ten slotte om der gevolgen wille wel het een of ander "moderamen" of "expediënt" zou móten uitdenken, hetzij met "het scheepsvolk iets op een gepermitteerde wijze toe te voegen van hetgene zij thans zoo excessief ter 
sluik en op allerhande sinistre wijze medenamen», hetzij op een andere manier. Want zij waren aan dezen ongeoorloofden handel te veel gewend geraakt "om haar alles af te snijden," en het was dan nog maar beter van twee kwaden het minste te kiezen "als op dien voet de schepen op een onbeschaamde wijze tegen wil en dank te zien volproppen.»

$\mathrm{Na}$ aldus hare bezwaren te hebben ontvouwd tegen de denkbeelden van de Zeventien zette de Hooge Regeering haar eigen plan voor de regeling van den Chinaschen handel uiteen. Voorop stellende dat het doel moest wezen dien voor de Compagnie tot het meeste voordeel te doen gedijen en tegelijkertijd voor de "vreemde Europeanen" zoo veel mogelijk te bemoeilijken, betuigde zij het met de Heeren in Patria volkomen eens te zijn dat de vaart op China vrij wat beter van Batavia uit was te doen dan rechtstreeks van uit Nederland, naardien de Compagnie hiervoor geen meerdere schepen behoefde dan die zij voor het tegenwoordige in het vaarwater had en de reizen van uit Batavia met versch volk niet alleen veel korter vielen maar ook aan veel minder moeilijkheden onderworpen waren. Men behoorde dan echter onze vaart te proportioneeren naar die van de Engelschen, Franschen en overige Europeanen en haar geen oogenblik langer in stand te houden dan zij de hunne. Welbeschouwd toch was de vraag niet zoozeer wie van al de liefhebbers het meeste profijt uit de Chinasche negotie zou trekken als wel wie haar het eerst zou opgeven. Ongetwijfeld, zoolang een iegelijk ze bleef voortzetten mocht ook de Compagnie er om geen reden ter wereld mede uitscheiden, vermits zij haar geheel aan anderen overlatende dezen nog al meer aanmoedigen zou. Doch van het oogenblik af dat onze mededingers hun vaart op China kwamen te staken, werden aparte bezendingen derwaarts van Compagnie's wege volslagen overbodig, want de Chineezen zouden dan voor de koopmanschappen, tot hiertoe in hun eigen land aan de Europeanen gesleten, gewisselijk een uitweg moeten zoeken op Batavia, en aldus zou de Compagnie "alleen genoegzaam meester en in staat blijven om van alles wat China uitleverde door het kanaal van Batavia jaarlijks goede partijen tegen redelijke prijzen op te doen.» Opdat zij nu de uitrusting van de Bataviasche Chinavaarders zouden kunnen regelen naar die van de Europeesche reeders, verzochten Generaal en Raden aan de Zeventien om hun telken jare tijdig over te 
brieven welke schepen en hoeveel men in Europa voor China gereed maakte, door middel van een welbezeild scheepje dat vroeg in het voorjaar te Batavia diende aan te komen en tegelijk de nieuwste patronen kon meebrengen van de in Europa meest gewilde porceleinen en stoffen. Voorloopig scheen het voldoende naar China vier schepen te zenden, drie met bestemming voor Nederland, het vierde voor den terugkeer naar Batavia. De eerste drie moesten, om in Europa althans niet later aan de markt te komen dan andere, evenals tegenwoordig rechtstreeks uit China naar de Vaderlandsche havens varen zonder de Bataviasche reede aan te doen, zoodat zij het gevaar ontliepen aldaar of omtrent Bantam te moeten opworstelen tegen de noorde- en noordwestewinden, die juist tijdens het aannemen der retourreizen uit China doorgaans zoo fel doorwaaiden dat er wel een maand of meer mede verloren ging. Om de bespoediging in dezen nog des te meer te bevorderen, spoorden zij de Heeren Meesters zelfs aan om ten allereerste in Nederland op stapel te laten zetten eenige snelvarende schepen; beter op de zeilage en lading berekend dan de gewone bodems der Compagnie, al was het ook zoo dat hare navale macht in Indië voor zulk een op te richten vaart tusschen Batavia en China toereikende was. Anders zou het verkrijgen van een vroegere terugreis van daar toch vruchteloos wezen, gesteld al dat zij te verkrijgen was, "overmits de vreemde schepen wel een maand op zoodanige reize in de zeilage vooruit hadden, ongerekend de vèrheid van de Nederlandsche havens in vergelijking van sommige uit de andere, en consequentelijk al echter bij ontmoetinge van egale winden, gelijk men naar de redelijkheid en billijkheid veronderstellen moest, nog eerder aan de markt zouden kunnen zijn als de onze, al kwamen die veertien dagen vóór haar te vertrekken.» ${ }^{1}$ Mochten verder de drie voor Patria bestemde vaartuigen op hun heenreis bij geval een lading inhebben van louter ballast, bestaande in sappanhout, suiker en tin, zoo verdiende het aanbeveling die in China van de hand te doen en als het kon te vervangen door een onderlaag van porcelein, welke in Europa denkelijk meer winst zou geven dan de suiker en het tin, waarop trouwens ook in China, welgewild als die daar

1 Wegens onze ondiepe zeegaten en om meer lading te kunnen innemen waren onze Oostinjevaarders van logger bouw en minder snedig in de vaart dan die van andere natiën. 
waren, voordeel viel te behalen. Tot het eigenlijke negotiewerk oordeelde de Hooge Regeering een personeel noodig van vijf bedienden met een opperkoopman aan het hoofd, welke laatste na afloop niet naar Nederland doch naar Batavia moest terugkeeren. Van het opperbestier van iemand van dien hoogen rang, meende zij, mocht zoowel een betere loop van de zaken worden tegemoet gezien als meer ontzag onder het scheepsvolk, als zijnde hij bevoegd hen, die het te bont hadden gemaakt, ter verkrijging van hun straf mede te brengen naar Batavia. Werd dit personeel in het begin van Mei met een van de schepen vooruit gezonden, dan zouden de drie overige, welke eerst anderhalve of twee maand na dien behoefden af te zeilen, in tijds de vereischte lading gereed kunnen maken en aldus een vermindering te weeg brengen in de onkosten van de ligdagen. Zoodra de drie voor Nederland bestemde kielen waren volgeladen, moesten zij ten spoedigste derwaarts vertrekken onder het opperbevel van een der negotiebedienden, die de Bewindhebbers van het verrichte rekenschap had te geven, gelijk wederkeerig de naar Batavia terugkeerende aan Generaal en Raden zouden moeten doen. Daarentegen kon het vierde, voor Batavia aangewezen, schip nog wel een paar maanden langer, dat is tot half Februari, in China blijven liggen, waardoor het gelegenheid bekwam om, na de afreis van de Europeesche schepen en van de meeste op Batavia varende jonken, voor het opdoen van zijn lading partij te trekken van de aanmerkelijke daling der marktprijzen, op dat tijdstip gewoonlijk invallende. Tegelijkertijd zou het bij de Chineesche kooplui alvast de leverantie kunnen aanbesteden van een of twee scheepsladingen ten behoeve van de in het naaste jaar te verwachten Compagnies bodems. Behalve de thee, alleen tot retourvracht voor dat vierde schip dienende, nog meer van deze waar naar Batavia mede te laten brengen, ontried de Hooge Regeering: de hieruit voortspruitende opdrijving van den prijs zou uitsluitend ten bate komen van de Chineesche verkoopers en tevens, tot schade van de Compagnie, veroorzaken dat de op Batavia varende jonken de hunne zooveel te duurder moesten inslaan terwijl zij anders, als zij die goedkoop konden meester worden, machtig bijdroegen tot den bloei van de Chineesche kolonie daar ter plaatse, de stadsinkomsten deden toenemen, en bovendien meest al hun geld weder besteedden voor het inkoopen van 
Compagniesgoederen, manufacturen, peper, tin en wat dies meer zij. Van den aanbreng der jonken mocht men zich nog een verder profijt beloven, indien de Bewindhebbers geliefden toe te staan dat in Mei en Juni, een tijdstip dat de Chineezen te Batavia gemeenlijk het meest met hun waren verlegen zaten, voor de Compagnie alles mocht opgekocht worden wat maar als leverbaar goed kon beschouwd worden, altoos wanneer op den te besteden prijs eenige winst te verwachten was. Zoodoende namelijk zou men in staat wezen de thee voor evenveel of zelfs minder te bemachtigen als in China en bij een overvloedigen aanvoer twee à drie scheepsladingen goede soort naar Nederland kunnen verzenden welke, in September van Batavia afgezonden, in April of Mei, dus nog vóór die van andere natiën, in Europa aan zouden komen. Wat voordeelen zoodanige regeling inhield, was duidelijk: zij sneed aan de particuliere negotianten den pas af om zich in dien tijd van slapte zoo ruimschoots van goed te voorzien en er de Compagniesretourschepen zoo buitensporig mede te overladen als thans gebeurde, zij hielp den Chineeschen jonkenhandel op de been houden, en gaf eindelijk aan de Compagnie de macht in handen om door haar vroegere aankomst op de Europeesche markt met deze goedkoope thee aan hare mededingers de wet te stellen en zelve buiten schade te blijven. Zelfs wierpen Generaal en Raden de vraag op of het niet wenschelijk was, dat de Compagnie zich uitsluitend tot het afhalen van porcelein, zijde, zijdestoffen enz. bepaalde maar de negotie van thee geheel aan de bewoners van Batavia overliet, om het artikel vervolgens tegen betaling van de vracht op haar schepen naar Europa te vervoeren. Aan een redelijk vrachtloon toch, zoo oordeelden zij, zou de Compagnie vooreerst stellig meer verdienen dan aan den theehandel voor eigen rekening. De middelen ter verwezenlijking van hun denkbeeld lagen voor de hand: men had er ieder jaar slechts een paar kloeke schepen voor te bestemmen, twee of drie al naar gelang van de grootte der aangeboden partijen, het goed na zijn overkomst in het Vaderland in de pakhuizen van de Compagnie op te slaan om het vervolgens door haar te laten verkoopen, en ten slotte de opbrengst, na aftrek van ongelden en veertig procent voor vrachtloon, aan de eigenaars uit te keeren. In aanmerking genomen dat diergelijke vrachtschepen hoofd voor hoofd zeer gemakkelijk 400.000 
pond thee konden innemen en gerekend dat de thee door elkander desnoods maar een prijs haalde van dertig stuiver het pond, zoo zou ieder schip 240.000 gulden aan vrachtloon besommen, en dit niet alleen zonder eenige meerdere risico dan die van het schip maar tegelijk zonder merkelijke onkosten, wijl zoo'n vrachtvaarder, als hij de reis deed onder het geleide van de andere retourschepen der eerste bezending, maar een bemanning behoefde van zeventig of uiterlijk tachtig ja bij doelmatige regeling wellicht nog vrij wat minder koppen. Wanneer men nu op grond van de ondervinding der laatste jaren den jaarlijkschen aanvoer van thee te Batavia op 30.000 pikols stelde, en al verder aannam dat de in bedenken gegeven maatregel den overvoer van particuliere thee naar Nederland zou beletten, of «dat hoekje ten minste zóóver te boven komen kon » dat de 2500.000 pond welke, gelijk de Bewindhebbers klaagden, thans op die ongeoorloofde wijze met de Compagniesschepen naar Patria werd overgebracht, tot op de helft of 10.000 pikols werd verminderd, dan durfden Generaal en Raden zich beloven dat de resteerende 10.000 op vracht zouden medegegeven worden, wat volgens hun becijfering voor de Compagnie een vrachtloon zou opleveren van omtrent twaalf ton gouds, een winst zoo groot als zij met haar theenegotie op den tegenwoordigen voet gewis niet maken kon. Met het fnuiken van dien verboden particulieren handel, zeggen zij, moest tevens noodwendig een afneming gepaard gaan van dat andere ingekankerde kwaad, het overladen van de retourschepen. Want welk Bataviasch ingezetene zou zijn goed aan de particuliere zorg van het ruwe scheepsvolk willen toebetrouwen wanneer hij het op veilige wijze door tusschenkomst van de Compagnie zelf kon overzenden? Matrozen en verdere zeevarenden zouden dus, indien zij onder hun kooigoed ter sluiks de een of andere waar mochten willen medebrengen, deze uit hun eigen beurs moeten inkoopen doch dit kon wegens de armoede van de meesten nooit veel te beduiden hebben. Opdat zij evenwel tot geen moedeloosheid of muiterij vervielen maar integendeel de handen wat ruimer kregen, ried de Hooge Regeering aan om de matrozen en soldaten voor hun daarbij te lijden verlies schadeloos te stellen met een equivalent, bijvoorbeeld hierin bestaande dat zij op de retourreis boven en behalve de hun toegestane bagage een hoeveelheid thee mochten medenemen van honderd pond bruto. Daarmede 
werd hun "gratie genoeg» gedaan en "de maat» zoo "volgemeten," zóó billijk met hen gehandeld in één woord, dat alsdan alle overtredingen op dit stuk door de Compagnie ten strengste konden worden gestraft zonder eenigerlei gevaar voor schadelijke gevolgen. Aangezien echter het overladen van de schepen met thee en kooigoed aan den gemeenen man alleen niet te wijten was, maar evenzeer ja mogelijk wel voornamelijk zijn oorsprong vond in de onverzadelijke hebzucht van de overheden der schepen, behoorde men dezen insgelijks aan een verordening te binden die naar gelang van een ieders qualiteit de hoeveelheid thee vaststelde, welke hij vrij mocht overvoeren. Werd zij voor de hoogergeplaatste officieren op 40 à 36 tot 10 à 9 en voor de allerlaagsten in rang op 6 kanassers bepaald zoo zouden, aangenomen dat ieder «in staat was zijnen gepermitteerden tax te voldoen," met elken bodem door elkander 550 kanassers kunnen medegebracht worden, of met dertig schepen te zamen omtrent 16500 kanassers of ruim 8000 pikols, zijnde dus ruim de helft minder dan de 20.000 pikols, die volgens de klachten van de Heeren Zeventien tegenwoordig onder den naam van kooigoederen in Nederland werden ingevoerd. Betuigde wijders de Hooge Regeering haar volkomen instemming met het door de Zeventien geopperde denkbeeld, dat wij met Engeland dienden overeen te komen om de "lorredraaiers" uit België mitsgaders alle andere schepen aan te houden en te confiskeeren, die men beoosten de Kaap aan mocht treffen met passen van andere Souvereinen dan hun eigene, minder ingenomen was zij met een tweede denkbeeld van de Zeventien, te weten of men niet evenals de Engelschen voorhadden van Compagnie's wege de vreemde Europeesche schepen in Indië, met name de Zweedsche, behoorde te visiteeren ten einde er de Nederlanders af te lichten, die in strijd met de herhaaldelijk uitgevaardigde plakaten bij zulke buitenlandsche Oost-Indische Compagnieën dienst hadden genomen. $\mathrm{Zij}$ vond de gestrenge doorzetting van den maatregel even zorgelijk als de slappe uitvoering, waartoe zij zich zou gedwongen zien als haar geen "genoegzame en toereikende orders» werden verstrekt om bij ontmoeting van tegenstand «'s Compagnies respect" naar behooren te kunnen "souteneeren»: in het eerste geval had men groote moeilijkheden te verwachten, in het tweede werd de Nederlandsche naam in Indië aan openbare bespotting overgeleverd.

Eindelijk de vraag aanroerend of er tot stremming van den 
Chinaschen handel der vreemde natiën geen andere middelen meer waren te bedenken, verklaarde de Hooge Regeering dat het wel overweging verdiende het Hof van Peking indien mogelijk een zoodanigen afkeer van de komst der Europeesche kooplieden in te boezemen, dat bij slot van rekening hun vaart op China tot die van de Compagnie incluis ten eenenmale zou worden verboden. Een verbod huns inziens des te gemakkelijker te bewerken, zoo men den Keizer slechts wist duidelijk te maken dat hij daar niets bij verloor, aangezien China immers door de vaart der jonken op Batavia alzoowel van zijn voortbrengselen ontlast kon worden als nu door de Europeesche schepen, maar integendeel door zoo te doen zijn onderdanen een merkelijk voordeel zou toevoegen, wijl zij dan alleen den uitvoer in hun macht zouden hebben. Nog veel radicaler was de oplossing door één afzonderlijk lid van de Hooge Regeering aanbevolen. Naar diens gevoelen behoorde men niet alleen de vaart af te schaffen van Nederland op China, doch er ook geen te beginnen van Batavia derwaarts. Op denzelfden trant als thans de particuliere kooplieden uit China jaarlijks overvloedige voorraden thee te Batavia aanvoerden tegen matige prijzen, zouden zij daar allengs ook de partijen porcelein en zijdestoften kunnen bezorgen, meende hij, welke sinds eenige jaren met de van Nederland uitvarende schepen van Canton werden afgehaald. Hoezeer de Compagnie hierbij gebaat zou zijn, sprong in het oog: de zware kosten van de uitrusting der schepen, de risico ter zee, de lasten verbonden aan het verblijf te Canton, van dit alles zouden zij dan zijn ontslagen. Het voorbeeld van de Bataviasche liefhebbers die met de afvarende jonken de monsters plachten mede te geven, waarnaar zij de verlangde stoffen en porceleinen wenschten vervaardigd te hebben, en het bestelde naderhand door hun bemiddeling thuis kregen, wees in dezen den weg. Waarom zouden de Bewindhebbers van de in Europa best gewilde assortimenten geen monsters naar Batavia oversturen, opdat Gouverneur-Generaal en Raden daar evenzoo mede handelden als de Bataviasche ingezetenen met de hunne? Zelfs ware de «inzaam» van de voor het Vaderland benoodigde partijen veel voordeeliger te doen door de Compagnie dan door particulieren, mits zij slechts zorgde voor een genoegzamen voorraad van peper enz. om de jonken aan retourvracht te kunnen helpen. Dit, zoo merkte hij aan, zal den jaarlijkschen omzet van Dl. 73 
goederen uit haar pakhuizen tegelijk met de Bataviasche winsten, "die op alzulken gesorteerden cargasoen door den anderen rekenbaar zijn tot ruim 67 procent "sterk doen toenemen; verhinderen dat er zulke aanzienlijke bedragen aan zilver naar China wegvloeien als in de laatste jaren heeft plaats gehad tot groot ongerief van de burgerij, die het nimmer zag wederkeeren; een stijging veroorzaken in de opbrengst der in- en uitgaande rechten, door de Chineezen hier ter stede verschuldigd; - kortom met de vermeerderde levendigheid van de jonkenvaart tegelijk de algemeene welvaart van Batavia verhoogen. Stelden sommigen in den Raad van Indie ter bestrijding van zijn voorslag de vraag, wat winsten men op zulken aanvoer van porcelein en zijdestoffen wel aan de Chineezen diende toe te leggen zóódanig dat zij er zelf van konden bestaan en de Compagnie er geen "merkelijke kosten» voor maken moest, voor wie bedacht hoe goedkoop die natie placht te varen viel dat bezwaar van zelf weg, oordeelde hij. Zoodra toch deze of gene reeder de door hem gekochte jonk voorzien had van zeil, treil, houten ankers, rottingtouwen en drinkwater had hij geen de minste scheepslasten meer te dragen, want de bemanning kostte hem niets, zij voer mede "op haar eigen kost» en werd voor haar diensten bezoldigd niet in den vorm van gages maar met het verlof om vrachtvrij "een zeer geringe zwaarte in smalle cargasoentjes» mede te nemen. Derhalve bleef «de vracht, die het jonksruim afwierp», geheel voor den reeder, waarbij dan nog kwam het passagegeld, ten bedrage van tien rijksdaalders de persoon, van de 150 tot 200 passagiers die geregeld met elke jonk medekwamen. Alles bijeen genomen sprak het dus van zelf dat de scheepsvrachten op den aanvoer hunner koopmanschappen voor de Chineezen niet hoog op stok konden loopen. Hiervan was hij in allen gevalle vast overtuigd, als hun voor den aanbreng maar iets meer werd toegelegd dan het gezamenlijke bedrag van den inkoopsprijs en de rechten op Batavia, zoo zouden de Chineezen door middel van de winst op hun gewone retourgoederen boven en behalve hun "noodwendig smal bestaan" wel datgene weten te profiteeren, waartoe de Compagnie wegens de kostbaarheid van haar eigen uitrustingen naar China onmogelijk zou in staat wezen. '

1 Advies van den Raad-ordinaris van Indië Wybrand Blom van 17 Maart 1733 (Overgekomen brieven en papieren van Batavia van 1733.) 
Hoe radicaal het denkbeeld van dat ééne lid der Hooge Regeering ook zijn mocht, op zichzelf beschouwd leek het de Heeren Zeventien in geenen deele verwerpelijk. "Wij hebben, alzoo schreven zij Gouverneur-Generaal en Raden na van de uit Indië overgezonden adviezen op het stuk van Compagnie's Chinaschen handel kennis te hebben genomen, *wij hebben wel eenpariglijk geoordeeld best te wezen indien men alle bezendingen met 's Compagnie's schepen naar China konde vermijden, zoo die uit Europa gedaan worden als die men volgens UEd. voorstel van Batavia derwaarts zoude kunnen doen, en dat men de Chineezen mocht gewennen om haar koopmanschappen met haar eigen jonken of vaartuigen op Batavia aan te brengen in zulk een quantiteit en sorteering als die van tijd tot tijd door ons zullen worden gepetitioneerd. ${ }^{1}$ Aan den anderen kant echter waren zij beducht dat dit "somtijds zoo heel zeker niet zou gaan", of op zijn best genomen althans "vrij wat meer tijd zoude vereischen om in trein gebracht te worden als wanneer men hoe eerder hoe beter dispositie kwam te maken om een bezending van Batavia naar China te doen, en de schepen zoo directelijk exempt één naar Nederland te doen repatrieeren.»² Vandaar dat zij, alles rijpelijk overdacht en overwogen, in hun vergadering van 11 Maart 1734 het besluit namen om met de directe vaart van Nederland naar China op te houden, maar daarentegen aan Gouverneur-Generaal en Raden order te geven dat zij rechtstreeks van Batavia twee schepen ter negotie daarheen zouden zenden, een van 145 en een van 120 voet doch het laatste eer kleiner dan grooter, en plaatsen daarop drie à vier personen tot het bestier van Compagnieshandel aldaar en dat wel met zoodanigen rang als zij geraden mochten vinden. De schepen zouden tot onderlaag moeten hebben suiker, sappanhout, tin of andere waren doch niet mogen beladen worden met zulke goederen als de Chineesche jonken jaarlijks van Batavia kwamen afhalen. Ook zouden de naar China uit te zenden negotiebedienden de jonken daar te lande "in alle manieren moeten animeeren om de gerequireerde goederen op Batavia aan te brengen. Het grootste van die beide schepen moest zoodra het volgeladen was van China regelrecht naar Nederland

1 Brief van de Zeventien aan Gouverneur-Generaal en Raden 12 Maart 1734.

2 Als voren.

Dl. 73 
varen, zonder onderweg ergens aan te loopen behalve alleen aan de Kaap tot het innemen van verversching, terwijl een van de bedienden daarop naar het Vaderland moest medegaan om aan de Bewindhebbers van het handelsbedrijf verslag te doen. Het kleinste schip had naar Batavia terug te keeren met de overige bedienden aan boord, ondat dezen van hun doen en laten verantwoording zouden kunnen doen aan GouverneurGeneraal en Raden. Ter bekostiging van het uitrusten der schepen zou in zilveren muntspecie naar Batavia worden afgezonden een kapitaal van zes ton gouds. ${ }^{1}$

Wat oogmerk de Zeventien nastreefden en in welken geest zij hun besluit wenschten te zien uitgevoerd, lichtten zij nader toe in den brief waarbij het aan de Heeren te Batavia werd medegedeeld. Wij laten, luidt het daar, "aan UEd. goedvinden over hoedanig UEd. dezelve schepen op haar afreize naar China zullen onderlagen of met hoedanige koopmanschappen voorzien, waaromtrent wij in het generaal maar kunnen zeggen dat het zeer goed zoude wezen' indien men de grove waren als suiker, sappanhout, lood etc. en inzonderheid diegene, die ons in Europa over de hand zijn als de suiker en het lood, in het Chineesche rijk konde debiteeren, indien men voor het provenu derzelve de Chineesche koopmanschappen voor een groot gedeelte konde inhandelen en de schepen in plaats van de grove waren van een onderlaag van porcelein voorzien. Maar dewijl wij nevens UEd. ook wel considereeren dat alle bezendingen met Compagniesschepen naar het Chineesche rijk, al is het dat die over Batavia gedaan worden, zeer kostelijk zullen vallen en mogelijk niet minder dan uit Europa zelve aanleiding geven tot velerlei particulieren handel, vinden wij niet geraden deze afgaande schepen met veel koopmanschappen te beladen om die in China te debiteeren, ten ware gelijk UEd. dat wel hebben aangemerkt een gunstige occasie voorkwam om de grove waren voor porcelein te verruilen en om te zetten, hetwelk men dan voor een enkele reis zoude kunnen doen, en tegelijk wel moeten opletten of de Chineezen, die gewoon zijn de thee en andere waren op Batavia aan te brengen, daardoor ook mochten benadeeld worden. Want als de Compagnie de goederen, die deze luiden gewoon zijn van Batavia af te halen, in China zelve komt aan te brengen, is

1 Resol. XVII 11 en 12 Maart. 1734. 
er niets anders te wachten als dat de Chineezen naar mate zooveel minder zullen inkoopen als de Compagnie in China aanbrengt en dienvolgende de terugreize wanladen moeten ondernemen, ten ware dat de tijd kwam te leeren dat het debiet tot Batavia daardoor niet minder wierd en het wijduitgestrekte Chineesche rijk door dien gemakkelijken aanbreng des te meer kwam te consumeeren, dat alsnog onzeker is en van den tijd zal dienen afgewacht te worden. Uit dezen inzicht en bekommering hebben wij geprefereerd maar twee in plaats van vier schepen over Batavia naar China te zenden, namelijk om den handel der Chineezen geen nadeel toe te brengen aan dit hoofdcomptoir, ${ }^{1}$ en dewijl ons voor den dienst van de Compagnie ver het beste voorkomt deze navigatie en commercie tot Batavia meer en meer aan te kweeken en te augmenteeren, dat zekerlijk nog al eenigen tijd zal vereischen om in trein te brengen en ondertusschen in Europa in geen verlegenheid of gebrek van Chineesche koopmanschappen te geraken. Zoodat deze bezendinge 's Compagnie's wege ten deele maar geschiedt uit noodzakelijkheid, en ten deele om een proef te nemen wat door den tijd best zal bevallen en of het groote oogmerk, dat wij daarmede vóórhebben, zal kunnen bereikt worden om het debiet van 's Compagnie's koopmanschappen grooter te maken en tegelijk onze Europeesche competiteuren door een grooter aanbreng van Chineesche koopmanschappen meer afbreuk te doen op een wijze, die profitabelder en onkostelijker is mitsgaders aan minder inconvenienten onderhevig dan tot dusverre de directe vaart uit Europa is geweest. Men zal dan in voege voorschreven de bezending naar China wel mogen ondernemen maar ondertusschen tot Batavia niet stil zitten, als de gelegenheid het presenteert, om zooveel Chineesche koopmanschappen van thee, porcelein, ruwe en gewerkte zijde en wat dies meer is tot redelijke prijzen in te koopen, mits dat ook alles goed in zijn soort zij, en dan verder spreken met de koopluiden en nachoda's ${ }^{2}$ of zij zouden willen aannemen jaarlijks zooveel goederen in soorten op Batavia aan te brengen als men van hier volgens zekere monsters, die wij UEd. almede zonder tijdverzuim zullen laten gereedmaken en toezenden, komt te eischen. En naar dat dit van succes zal wezen of niet, zal men

1 Batavia namelijk.

2 Dat is: schippers, zie Hobson-Jobson, A glossary of eolloquial AngloIndian words ete., London $1903, \mathrm{i} . \mathrm{v}$, nacoda. 
bij vervolg van tijd de directe vaart van Batavia naar China dienen te reguleeren, de equipagiën derwaarts te verminderen of wel geheel te intermitteeren, alsmede de inkoopen der goederen die buiten zoodanige eischen door de Chineezen casueel zullen worden aangebracht. Zoo het mocht komen te gebeuren (zeggen zij ten slotte) dat onze particuliere eisch of monsters niet tijdig genoeg op Batavia mochten aangekomen zijn, zal echter als de tijd daar is te weten in de maand Mei van het jaar 1735 de reize naar China maar moeten ondernomen worden, en alsdan ingekocht hetgeen men best zal kunnen krijgen van goede soorten van thee en zijdestoffen mitsgaders van porceleinen, bestaande in koffie- en theegoed, hoog stelgoed tot sieraad op de schoorsteenen hetzij van gekleurd of mooi blauw, en inzonderheid serviezen voor tafels van schotels, borden en wat verder daartoe behoort. En wordt in het generaal nogmaals gerecommandeerd om zooveel suiker en grove waren hetzij tot Batavia ${ }^{1}$ of wel in het Chineesche rijk te debiteeren als mogelijk is en UEd. met den meesten dienst van de Compagnie zullen bevinden te behooren.» ${ }^{2}$

Met het besluit van Maart 1734 werd een regeling ingevoerd die, ofschoon enkel als proefneming bedoeld, gedurende een reeks van jaren heeft stand gehouden. Van Juni 1735 af, toen de eerste twee Compagniesbodems van Batavia naar Canton uitliepen, ${ }^{3}$ tot in het jaar 1756 toe bleef het werk van den Chinaschen handel aan het onmiddelijk bestier van GouverneurGeneraal en Raden toebetrouwd, op gelijke wijze als dat van de andere takken van den Indischen handel. Mag de Compagnie er ook onder den nieuwen staat van zaken niet in zijn geslaagd hare Zweedsche en andere Europeesehe mededingers uit het Chineesche vaarwater weg te dringen, in de verwachting dat het gewijzigde stelsel veel voordeeliger zou blijken is zij niet beschaamd geworden. Terwijl voorheen de van uit Nederland naar Canton afgaande kielen schier geheel ballastscheeps moesten varen, konden van nu aan alle Compagniesbodems zonder onderscheid op de heenreis naar Indië worden bevracht met de koopwaren en provisiën, welke onze comptoiren daar te

1 Te weten aan de daar aankomende Chineesche jonken.

2 Brief XVII aan Gouverneur-Generaal en Raden 12 Maart 1734.

${ }^{3}$ Generale missive van Gouverneur-Generaal en Raden aan de XVII 12 Oet. 1735 . 
lande noodig hadden en die doorgaans van zoo grooten omvang waren, dat men er jaar in jaar uit vele door gebrek aan scheepsruimte niet kon afzenden. Verder konden de Chinavaarders, in plaats van gelijk tot dus ver voor hun inkoopen uitsluitend contanten mede te nemen, zich te Batavia voor dat doel van allerlei Indische waren voorzien inzonderheid van specerijen, waarop in China zoo groote winsten vielen "dat genoegzaam het geheele retour daarvoor kon worden ingekocht.» Een derde voordeel bestond hierin dat, waar men te voren de gages van carga's en scheepsvolk ten minste tot Straat Soenda toe als "vruchteloos» had te beschouwen, deze thans, nu Batavia werd aangedaan, wel degelijk met vrucht werden besteed. Eindelijk, dewijl de Compagnie in Indië voortdurend gebrek had aan Europeesch volk en de groote schepen op hun uitreis "met twee derden meerder koppen waren bemand dan op de thuisreis en de kleinere naar advenant, zoo sprak het van zelf, naar een kundig tijdgenoot opmerkt, «dat door het zenden van schepen naar China van Batavia Indië.in haar groot gebrek aan Europeesche soldaten en matrozen werd gesoulageerd, waarvan zij door de directe vaart van hier ${ }^{1}$ anders bleef destituut. ${ }^{2}$ In het laatste geval toch plachten de schepelingen met dezelfde bodems, waarop zij naar China uitzeilden, weder naar het Vaderland terug te komen, zoodat men diegenen van hen, die anders voor de thuisreis te missen waren, niet gebruiken kon tot aanvulling van het in Indië heerschende tekort.

\footnotetext{
1 Namelijk uit Nederland.

2 Consideratiën rakende den handel op China door Thomas Hope overgegeven aan Prins Willem V.
} 